Portland State University

PDXScholar

$1-1-1985$

\title{
Women's labor force supply and commuting behavior: a time-budget analysis
}

Ta-Win Lin

Portland State University

Follow this and additional works at: https://pdxscholar.library.pdx.edu/open_access_etds Let us know how access to this document benefits you.

Recommended Citation

Lin, Ta-Win, "Women's labor force supply and commuting behavior: a time-budget analysis" (1985). Dissertations and Theses. Paper 452.

https://doi.org/10.15760/etd.452

This Dissertation is brought to you for free and open access. It has been accepted for inclusion in Dissertations and Theses by an authorized administrator of PDXScholar. Please contact us if we can make this document more accessible: pdxscholar@pdx.edu. 
WOMEN'S LABOR FORCE SUPPLY AND COMMUTING BEHAVIOR:

A TIME-BUDGET ANALYSIS

by

Ta-Win Lin

A dissertation submitted in partial fulfillment of the requirements for the degree of

DOCTOR OF PHILOSOPHY

in

JRBAN STUDIES

Portland State University

1985 
TO THE OFFICE OF GRADUATE STUDIES AND RESEARCH:

The members of the Committee approve the dissertation of Ta-Win Lin presented August 27, 1985.
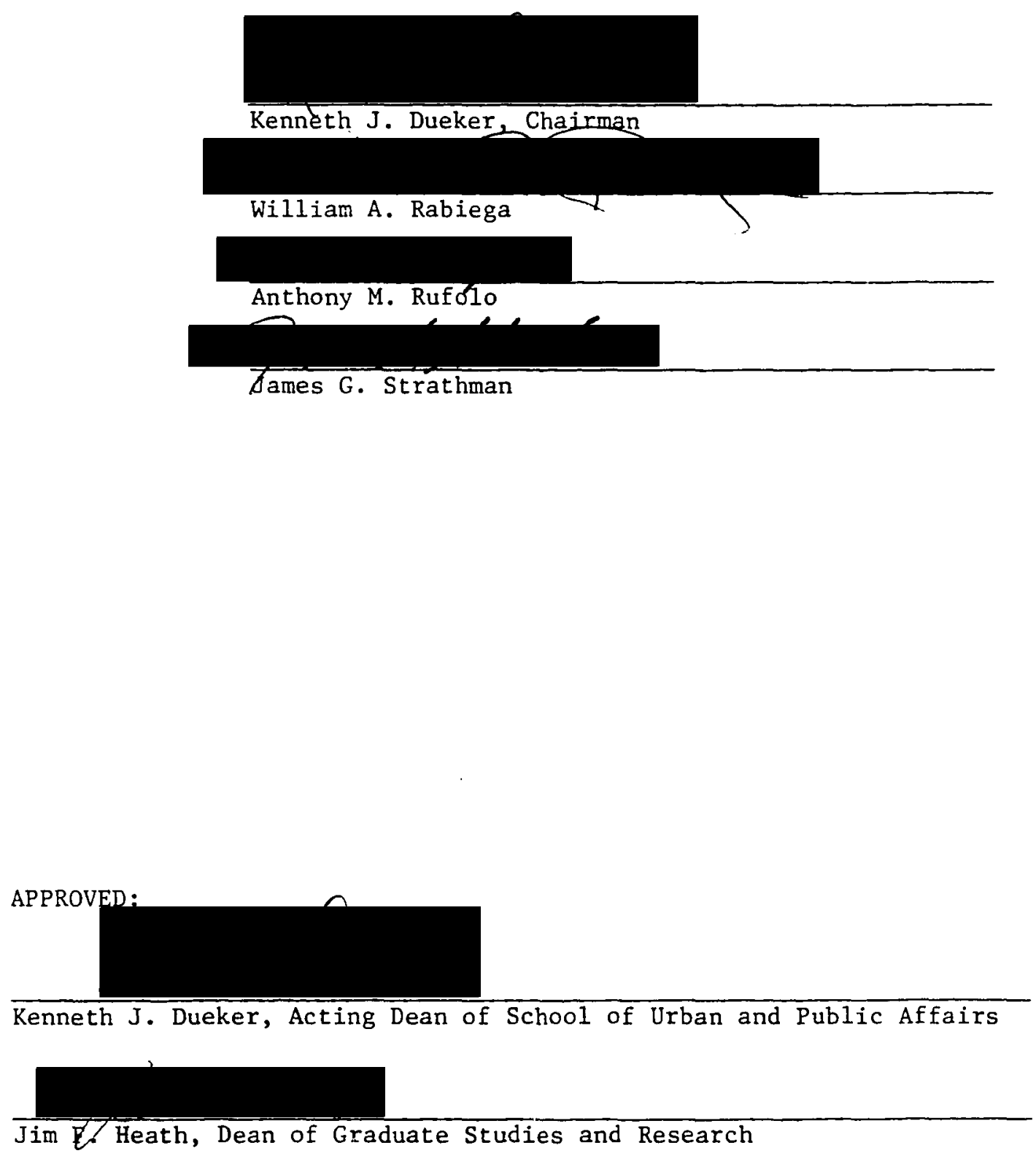
AN ABSTRACT OF THE DISSERTATION OF Ta-Win Lin for the Doctor of

Philosophy in Urban Studies presented August 27, 1985.

Title: Women's Labor Supply and Commuting Behavior: A Time-Budget Analysis.

APPROVED BY MEMBERS OF THE DISSERTATION COMMITTEE:

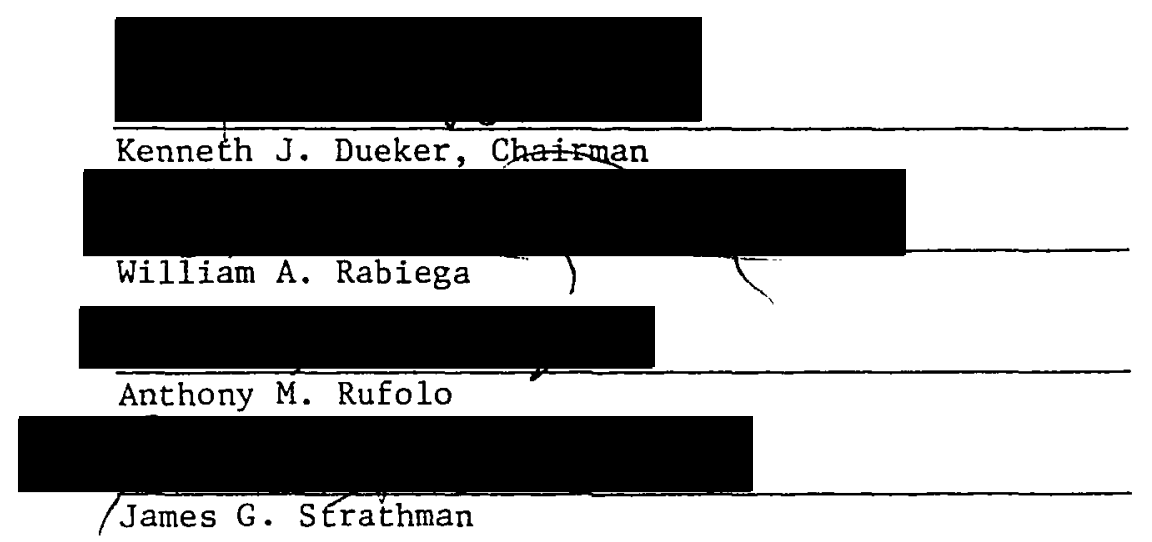

Female labor and commuting behavior has been inappropriately approached by traditional economic and location theories. While labor economists assume that commuting is a "fixed" element of the costof-entrance, they ignore the spatial variation in wage rate or job opportunities. Urban economists, on the other hand, treat the variation in commuting distance as a function of household housing consumption, and a "fired" amount of labor supply is assumed. Both assumptions are unrealistic, especially in the case of females. The major contention raised in this study is that labor supply and commuting behavior are interrelated decisions. This "simultaneity" relationship should be 
captured by any model studying either labor or commuting behavior. In the case of female household members, time as a scarce resource must be allocated more efficiently since women are traditionally assigned housework responsibility--be they housewives or working women.

A simultaneous-equation model has been specified to simulate the household decision of appropriating its (economic and human) resources among female income-earning activities--i.e., market labor supply and commuting--and housework. Time is adopted as the measurement unit of the three endogenous variables. Demographic and environmental variables are included in order to obtain the most efficient estimation and to link the results of this research to other economic and sociological studies. A two-stage Tobit and OLS estimation procedure is employed, according to the characteristics of the data, to avoid the selection bias problem (Tobin, 1958; Killingsworth, 1983). The results derived give (empirical) support to the theoretical argument that the relationship between commuting and labor supply is nut a single-direction one, suggesting that the estimation of the traditional single-equation model may well be subject to serious specification bias.

The theoretical and empirical inferences provided by this study contribute to a better understanding of how a household perceives its female members' domestic service and income-earning activity. Also, theoretically, the estimation can be used to give a more precise measure of the local (potential) labor pool and a more precise prediction of the amount of (female) commuters using certain routes. 
All these contributions have significance with respect to the firm's location decision and production planning, and the planning for the provisions of other public services. 


\section{ACKNOWLEDGEMEN'S}

I would like to take this opportunity to express my sincere thanks to the members of my dissertation committee for their help and guidance. Special thanks go to my advisor, Dr. Dueker, for his patience, criticism, and encouragement in directing this research to its conclusion.

I am grateful for the emotional and material support of my parents, Shin-Rong and Yin-Chung Lin, and my wife, Mei-Lin Chen. Also, the birth of my son, Alan Lin, has motivated me to expedite steps toward completion of the degree. 
TABLE OF CONTENTS

PAGE

ACKNOWLEDGEMENTS . . . . . . . . . . . . . . . . . . . iii

LIST OF TABLES ...................... . . . . vi

LIST OF FIGURES . . . . . . . . . . . . . . . . . . vii

CHAPTER

I INTRODUCTION . . . . . . . . . . . . . . . . 1

Problem .................... 1

Relevant Literature .............. . 2

Why Female ................. 8

Female Labor Behavior: A Historical Review . . . . . 11

II THEORETICAL REVIEW . . . . . . . . . . . . 18

The "New Home Economics Approach" . . . . . . . 25

The Permanent Income Theory . . . . . . . . . 34

The Market Condition ............ 36

Market Segmentation............. 41

A Sociological Supplement . . . . . . . . . 48

III MODEL SPECIFICATION . . . . . . . . . . . 54

Estimation ................. 62

IV DATA AND MEASUREMENT . . . . . . . . . . . . . . . 68

Data .......................... 68

Measurement .............. . 70

V EMPIRICAL RESULTS . . . . . . . . . . . . . 77 
VI CONCLUSION . . . . . . . . . . . . 105

Implications for the Labor Economy ........ . 107

Implications for the Urban Economy ........ . 110

Discussion ............... 113

BIBLIOGRAPHY . . . . . . . . . . . . . . . . . 118

APPENDIX

A THE CRITERION VARIABLES USED TO SELECT OBSERVATIONS . . . 136

B DATA BASE CONSTRUCtion (THE VARIABLES USED IN THE MODEL) • 137

C THE DESCRIPTIVE STATISTICS OF THE VARIABLES . . . . . 142

D A PRELIMINARY ANALYSIS OF THE RELATIONSHIP BETWEEN MODE, COMMUTING, AND PLACE OF RESIDENCE . . . . . . . . 146

E THE RELATIONSHIP BETWEEN CHILDCARE COST AND THE PLACE OF RESIDENCE . . . . . . . . . . . . . . . . 152

F FEMALE LABOR FORCE PARTICIPATION RATE, BIRTH RATE, AND AGE AT FIRST MARRIAGE . . . . . . . . . . . . 154 
LIST OF TABLES

TABLE

PAGE

I Female Labor Force Participation Rate by Age,

United States . . . . . . . . . . . . . . . 12

II Labor Force Participation Rate of Married Women, Spouse Present, the United States . . . . . . . . . . 15

II Median Family Income, Male and Female Labor Force Participation Rate, 1947-1981 . . . . . . . . . . 22

IV Female Labor Force Participation Rate and Birth Rate, by Color . . . . . . . . . . . . . . . . 46

V Women's Annual Housework Hours . . . . . . . . . . . . 65

VI The Regression Estimates (White Households) . . . . . . 79

VII The Regression Estimates (Non-white Households). . . . . 82

VIII The Reduced-Form Equations (White Households) . . . . . 86

IX The Reduced-Form Equations (Non-White Households) . . . . 88

$\mathrm{X}$ The Wage and Spatial Elasticities of the Women's Labor Supply, and the Wage and Labor Elasticities of the Commuting Time . . . . . . . . . . . . . . 98

XI The Cross-Tabulation of Wives' Occupations by Husbands' Occupations (White) . . . . . . . . . . . . . 101

XII The Cross-Tabulation of Wives' Occupations by Husbands' Occupations (Non-white) . . . . . . . . . . 102 


\section{LIST OF FIGURES}

FIGURE

PAGE

1.1 The Trends of Female Labor Force Participation Rate, Birth Rate, Divorce Rate, and Age at First

Marriage ............. . . 10

2.1 The Income and Substitution Effects of the Wage Rate on an Individual's Labor Supply ........ 19

2.2 An Individual's Backward-bend Labor Supply Curve . . 20

3.1 The Selection Bias.............. 63

5.1 The Pathology of the Significant Wage Effects . . . 95 


\title{
CHAPTER I
}

\author{
INTRODUCTION
}

PROBLEM

\begin{abstract}
"It has always been assumed in the economic literature that the decision to consume is independent of the decision concerning where the consumption will be made. How true this is we cannot say..." (Rushton, 1969)
\end{abstract}

The inclusion of spatial factors has been shown to have a significant effect on the development of the production theory (Predohl, 1928; Hotelling, 1929; Weber, 1929; Smithies, 1941; Greenhut, 1952). In economic analysis, consumer behavior as approached through the utility theory is, mechanically, a counterpart of the firm's production process. It is particularly clear that, in recent years, the concept of the "New Home Economics," which views a household as a production unit, has been generally applied to studying household behavior--including its role as a labor supply unit. We can therefore expect that in the same economic system, spatial factors have the potential to play a significant part in influencing household behavior as input factors of its production process, as components of its utility function, or as constraints on household consumption or production behavior. This research is designed to study how spatial factors affect the labor supply decision of a female household member. Female labor force participation has been increasing steadily in the last two decades. In 1980 , more than $51 \%$ of the female 
population participated in market work, and their work trips account for $40 \%$ of all intraurban work trips (Madden \& White, 1980; Madden, 1981). Both women's labor and their commuting behavior should thus become an important concern for labor economists, transportation analysts, and public decision makers.

\section{RELEVANT LITERATURE}

In this section, two mainstreams of theoretical approaches to studying labor and commuting behavior will be discussed. Their strengths and weaknesses will be reviewed with respect to their basic assumptions, theoretical framework and model structure. Furthermore, their relative power in explaining real world phenomena will be addressed.

1. Urban economists have long employed a trade-off theorem to study the spatial effect on housing consumption (e.g. Wingo, 1961; Alonso, 1964; Muth, 1969). In this theoretical framework, an individual's work status, wage rate, and his employment location are assumed to be fixed or predetermined. A household selects a place of residence which minimizes the combination of housing costs and commuting costs. Longer commuting distance to work or higher transportation costs are thus explained as a compensation for lower housing prices at that location. The empirical fact that higher income people usuaily commute for a longer distance is thus evidence that the income elasticity of the demand for (Iiving) space is higher than the income elasticity of the marginal cost of commuting (Helbrun, 1981), the reason for this being that more space is generally available only in 
outlying areas. Aside from the fact that this model fits poorly when explaining the real world situation--i.e., empirical data frequently shows a positive or insignificant relationship between commuting costs and housing costs (Cherlow \& Morgan, 1976), some of its assumptions seem unreal.

The theory assumes that labor supply, wage rates, and employment location are exogenous to the model. This is true only when job opportunity is perfectly inelastic across space and as a result, the burden of spatial friction wholly falls upon the workers. However, Goldner (1955) argued that, because of the size of firms and their isolation from residential areas, employers have to pay a premium wage in order to recruit workers from longer distances. In his argument, residential location was assumed to be exogenously determined because of several other factors (e.g., seasonal and cyclical factors, occupation, union rules, a family lifecycle, social agglomeration, etc.) which ai a considered more important than job location in determining the choice of a "residential area." Thus, to the extent that job location is insignificant in residential location choice, the employer who chooses his plant location at a certain distance from the "predetermined" residential site is supposed to pay (at least a significant portion of) the commuting costs incurred. Nelson (1973) further developed this line of argument by examining the relationship of wage rate to firm size relative to population density. Population density and distance traveled are recognized as two important determinants of the wage elasticity of labor supply to the firm. He concluded that the supply of labor to the firm is directly 
proportional to the population density of the area surrounding the firm, given the prevailing market conditions. Rees and Shultz (1970) then offered more of a compromise in their argument. While admitting the validity of the trade-off theorem which suggests an interchangeable relationship between transportation costs and housing consumption, they also tested the relationship of distance to wage rate by including distance from home to work as an independent variable in the wage equation, thereby deriving a positive sign for most occupations. Wales (1978) continued in this direction and devised a labor supply model which incorporated commuting time in a utility maximizing framework. The marginal implicit price of commuting was assumed to be equal to the wage rate less the reduction in housing price which itself assumed a function of commuting time. While the effect of housing consumption was controlled in the model, a positive income (wage) elasticity for commuting time to work was still found.

To summarize, these theoretical and empirical results suggest that: first, spatial variation does exist in job opportunity and wage rate; and second, higher income or wage rate does usually induce longer commuting distances. This knowledge means that when we study women's commuting behavior, the assumption of "fixed" labor supply is hardly acceptable. In other words, the "simultaneous" relationship between commuting and labor supply behavior should be taken into consideration.

2. Labor economists generally study labor behavior by employing the reservation-wage theorem. That is, for every potential worker, there is a cost-of-entrance attached to his or her labor supply decision. 
The reservation wage is the highest wage at which a person will not work. That is, below this threshold, any minor change in price (wage) will not affect an individual's labor behavior.

There are several factors affecting an individual's reservation wage level. Among them, human capital investment, commuting costs, and household composition are the most important ones. Since in this framework the reservation wage 's predetermined, traditional economic research into labor behavior has relied upon empirical estimation using statistical techniques (e.g., Probit, Logit models) or upon direct use of surveys (e.g., the Panel Study of Income Dynamics) to derive the threshold value. However, recognizing the validity of the belief that commuting behavior is not only a predetermined factor but is itself activated by the labor supply decision, commuting costs should be a variable endogenous to the model. More specifically, taking for granted the argument that spatial variation in wage rate does exist (Rees \& Schultz, 1970; Madden, 1977), this theoretical framework suggests that individuals who make a labor supply decision will face a set of opportunities characterized by their spatial locations, each of which provides a combination of the reservation wage and the market wage rate. Any model failing to take into account the "simultaneity" relationship between commuting costs (and hence commuting distance) and wage rate (and hence labor supply) risks not being able to obtain unbiased estimates.

The above argument is especially valid for the female. Since women are still expected to assume the society-assigned role of home responsibility, the competition among housework, market work, and 
commuting for the limited time budget is thus more pertinent to female workers than to male workers. In the first place, higher commuting costs are only acceptable when they are satisfactorily compensated for by a higher wage (Rees \& Shultz, 1970; Cherlow \& Morgan, 1976; Madden, 1981); secondly, labor supply affects commuting behavior as it is supposed to generate income to cover the comnuting costs (White, 1977); thirdly, household factors play an important role in deciding women's reservation wage and labor supply behavior, and thus indirectly their commuting behavior.

Kasper (1983) strongly supports the simultaneity relationship by arguing that higher housing and/or journey-to-work costs not only determine income allocation, but also provide the incentive to obtain more income-re.g., an increase in housing outlay due to a change in family composition may cause increased (or decreased) labor force participation to help pay for the expense (or to fulfill the housework responsibility). He concluded that wage "is" a function of the costs of commuting.

Madden (1977, 1981) then argued that the difference in commuting distance cannot be attributed to differences in job location independently of residential location. A partial equilibrium model was established, treating work trip length as a result of the choices of household place of residence and job location--in other words, a labor supply decision has previously been made, and the spatial separation between the two locations is empirically estimated as a function of the labor market, housing, and household characteristics. The importance of household factors was identified. That is, the household composition, sex, and difference in household roles are 
significant factors in determining workers' mobility or the spatial elasticity of labor supply.

Summing up the above discussion, three points can be derived which are not independent of each other:

1. Research conducted by both labor economists and urban economists has made some unrealistic assumptions in explaining the spatial behavior of female labor supply. The urban economic household location model, which assumes fixed employment status, employment location, and wage rate is weakened by the existence of spatial variations in wage rate. Since labor supply is a function of wage rate, we can then expect the amount of an individual's labor supply to vary along the spatial dimension. On the other hand, the labor economist's labor supply model is handicapped by treating commuting costs as a fixed element of the reservation wage. Since the reservation wage is assumed exogenous to the model, comnuting costs thus become a "fixed" or predetermined variable in the model. In essence, both approaches have the disadvantage of not serving as a model for the mutual interrelationship of commuting and labor supply behavior.

2. The model adopted by labor and urban economists only partly explains the reality. Because of the unrealistic assumptions being made and the misspecified model structure, these models have given a poor performance empirically and have produced biased estimates of the price effect.

3. In the case of females, household factors are important as their sex-assigned role of doing (most of the ) housework still dominates our way of life. The "simultaneity" mentioned above should 
should then include housework in a study of women's labor and commuting behavior.

(It soon becomes evident that in a model intended to simulate all these interrelations, "time" would be the best measurement as a common dimension for the endogenous variables involved: commuting, labor supply, and housework.)

The method of research in this study is designed to correct these weaknesses through the employment of the household production theory (the "New Home Economics") which provides a sound theoretical framework for analyzing a household member's labor and commuting behavior (Chapter II) and the employment of a simultaneous equation model which more accurately simulates the mutual interrelationship between the endogenous variables (Chapter III).

WHY FEMALE

The strongest reason for prompting the focus of this study on female labor and commuting behavior is based on the "fact" that more and more women are involved in work outside the home. Consequently, the study has important implications for economic and social planning since a woman's labor behavior will significantly shape her own and her family's opportunities and constraints, and thus the household's consumption pattern. In addition to this, since work trips are a major source of VMT (vehicle miles of trave1) generated, the study is of importance to transportation planning or other public capital investment programs. On the one hand, it provides insight into the amount and the distribution of female workers' commuting trips; and on the other hand, it gives a more unbiased estimate of the valuation of 
female workers' commuting time expected in this study. This in turn may bring about an improvement in calculating the "benefit" of transportation projects. The study also has significance in the location decision of ecoinomic activities, especially for firms where work is mostly performed by female workers.

The second motivating factor which makes this subject worth our efforts is that it has been traditionally neglected in most research into labor behavior (Berk, 1980). For the most part, research in this field is male-oriented; a common assumption being that activities generating the gross national product (GNP) are "work" but all else is "leisure." This assumption is obviously not applicable to the situation of working women who are burdened with society's sexassigned role of housekeeping responsibilities. So the nature of female labor behavior is in fact much more complicated that that of the male--as partly indicated by the higher elasticity of female labor supply (Weisskoff, 1972) and their shorter commuting distance.

A third reason is that some social phenomena are clearly related to changing female labor behavior (Figure 1.1). So, research of this nature is useful in studying the effects of such social events as rising divorce rates (Hatch \& Hatch, 1968; Ladner, 1972; Hoffman \& Holmes, 1976; Kreps, 1976; Duncan \& Duncan, 1978), delayed marriage and the age of having the first child (Chafe, 1976; Oppenheimer, 1982) Taeuber \& Sweet, 1976), declining fertility rates (Kreps \& Leaper, 1976; Cramer, 1980), the increasing number of single-parent families (Moore \& Sawhil1, 1976; Glick \& Norton, 1977), and it is hoped that it can serve as an input to the formulation of public policies that deal with them. 


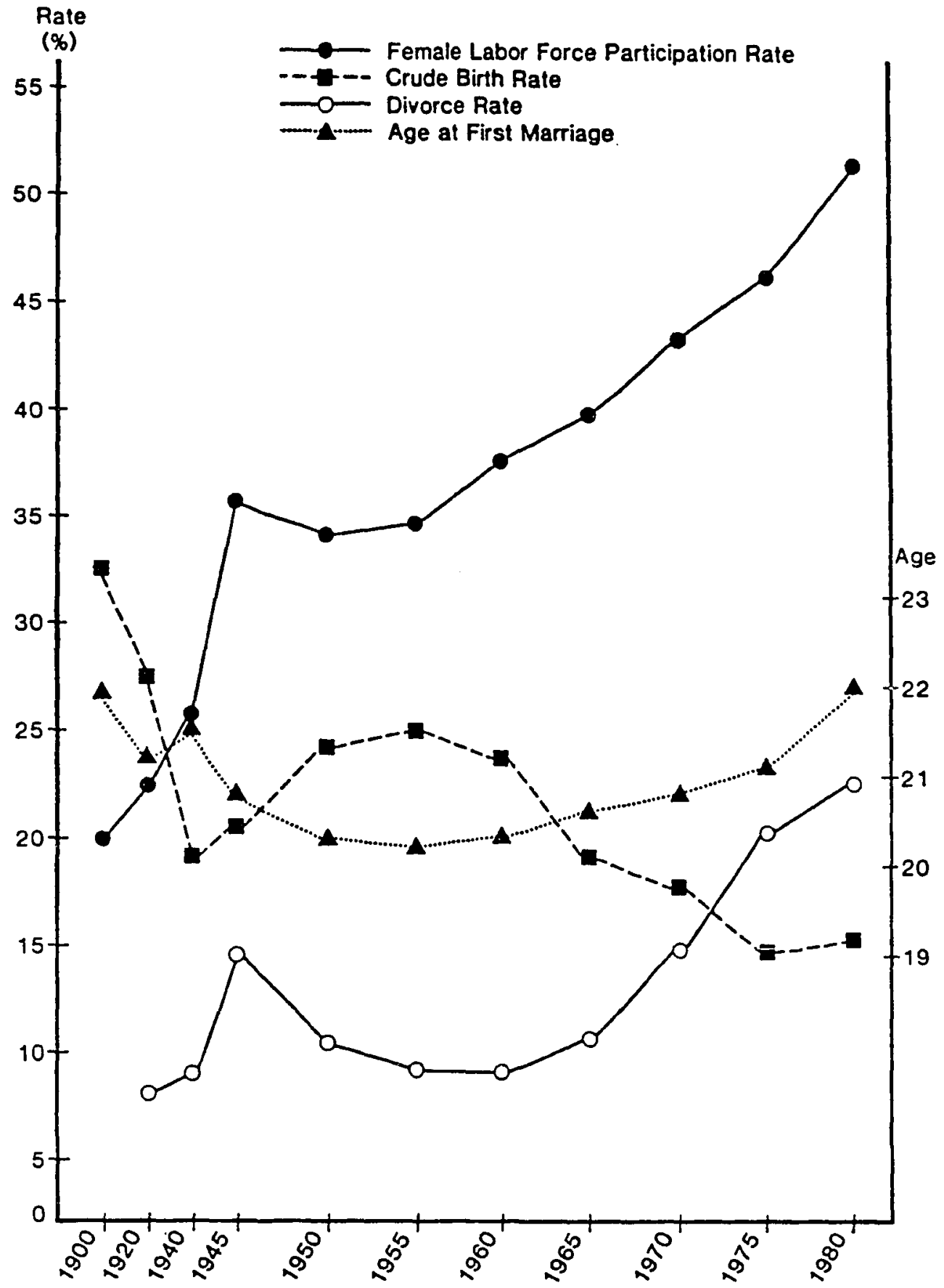

Figure 1.1 The trends of female labor force participation rales, crude birth rates, divorce rates, and ages at first marriage. (Source: Appendix F) 
FEMALE LABOR BEHAVIOR: A HISTORICAL REVIEW

The trend of changing female labor force participation is shown in Table I. Although women were actually the first industrial workers, the thorough-going domestication of American women occurred along with technological development and changing production processes. When the costs of moving pcople became lower relative to the cost of moving goods in an intra-urban context (Fales \& Moses, 1972), and when the new production methods encouraged large-scale production of goods formerly made in the home, the resulting urbanization (i.e., the concentration of people and economic activities) and residential suburbanization contributed to the removal of women from the mainstream of economic activity (Scott \& Tilly, 1975). Women's participation declined steadily because places of work became geographically distant from places of residence. During the period from the last part of the nineteenth century to the first four decades of the twentieth century, the female labor force was pretty stable. The withdrawal of middle-class white women was counteracted by the growing female labor participaiion rates of low-income people accompanied by the increasing population size, and the large amount of immigrants who were generally poor and needed income to support their new lives in the United States (Chafe, 1976). For middle-class women, the available factory jobs were dirty, unhealthy, and low-paid. Holding these kinds of jobs was considered as an infringement upon their social status. Hence, the separation of sexual spheres of activity was being formed, and childrearing and homemaking was becoming a full-time profession for women. For middle-class women in 
TABLE I

FEMALE LABOR FORCE PARTICIPATION RATE BY AGE, UNITED STATES

\begin{tabular}{cccccccc}
\hline & $\begin{array}{c}16(14)-19 \\
\text { Years }\end{array}$ & $\begin{array}{c}20-24 \\
\text { Years }\end{array}$ & $\begin{array}{c}25-34 \\
\text { Years }\end{array}$ & $\begin{array}{c}35-44 \\
\text { Years }\end{array}$ & $\begin{array}{c}45-54 \\
\text { Years }\end{array}$ & $\begin{array}{c}55-74 \\
\text { Years }\end{array}$ & $\begin{array}{c}65 \text { yr. } \\
\text { and over }\end{array}$ \\
\hline 1920 & 29.6 & 39.3 & 25.0 & 20.6 & 19.4 & 15.3 & 8.2 \\
1930 & 23.8 & 43.9 & 28.7 & 23.3 & 21.3 & 16.4 & 8.2 \\
1940 & 19.9 & 47.8 & 35.3 & 29.2 & 24.2 & 17.8 & 6.7 \\
1950 & 41.0 & 46.0 & 34.0 & 39.1 & 37.9 & 27.0 & 9.7 \\
1960 & 39.3 & 46.1 & 36.0 & 43.4 & 49.8 & 37.2 & 10.8 \\
1965 & 38.0 & 49.9 & 38.5 & 46.1 & 50.9 & 41.1 & 10.0 \\
1970 & 44.0 & 57.7 & 45.0 & 51.1 & 54.4 & 43.0 & 9.7 \\
1975 & 49.1 & 64.1 & 54.6 & 55.8 & 54.6 & 41.0 & 8.3 \\
1980 & 52.9 & 68.9 & 65.5 & 65.5 & 59.9 & 41.3 & 8.1 \\
1981 & 51.8 & 69.6 & 66.7 & 66.8 & 61.1 & 41.4 & 8.0 \\
\hline
\end{tabular}

SOURCES: (a) Hauser, P. M. (1954), "Mobility in Labor Force Participation," in Labor Mobility and Economic Opportunity, Preface by P. Webbink, Cambridge: The M.I.T. Press, P. 14, Table 3.

(b) U. S. Department of Labor, Bureau of Labor Statistics, December 1983, Bulletin 2175, Handbook of Labor Statistics 1983, Table 4. 
general, they left the labor market permanently at the time they got married or by the time they had the first baby (Taeuber \& Sweet, 1976). For those low-income families, the need for income overrode any other consideration. To sum up, the employment rates of all women during the period from 1900 to 1940 remained pretty stable--around 24 percent. World War II is generally recognized as a turning point in the labor pattern of American women $\omega$ most students in American economic history. During the war, both patriotism and the great demand for labor drew women of all ages into the labor force. In 1940, the female labor force participation rate was 25.6 percent. By the end of the War, it was 36 percent. About three-fourths of the new female workers were married. It was this working experience that made women realize that they could do most of the jobs traditionally held by men. A survey showed that most female workers enjoyed their jobs and wished to stay after the War (Gray, 1971; Chafe, 1976)--they enjoyed the material gain (i.e., pay), the opportunity to associate with other people at their workplace, and to free themselves from tedious housework. Although the return of the war veterans after the War drastically reduced jobs available for women, women were to some extent "emancipated" and a large proportion of them were prepared to take jobs if they became available. The changing pattern of female labor behavior in the following decades mirrors this persisting effect. Starting from the early forties, the female labor force participation rate has been rising dramatically. The first wave came from families where all the children were in school or had started leaving home. At this time, women considered re-entering the labor 
market. During the period from 1940 to 1950, the labor force participation rate of women in age cohort 45-54 had increased by 107 percent. By 1960 the labor force participation rate of women aged 35 to 54 had shifted markedly upward and exceeded that of women 18 to 24 years old. Subsequently, the higher education level and large demand led to a dramatic increase in the labor force participation rate of women before marriage or before the first child was born. The labor force participation rate of married women aged 20 to 24 rose by 58 percent during the 1960's. Finally, time-series data shows that, starting from the early $1960^{\circ}$, the labor force participation rate of young mothers started to increase rapidly--even for those mothers with pre-school children (Chafe, 1976; Fullerton, 1980; Fox, 1983). This trend is clearly shown in Table II.

It is worth mentioning that, after World War II, women coming from the middle classes tended increasingly to take market jobs. During the decade 1965-1975, the proportion of middle-class white families with two workers or more had increased by about 25 percent. Rising aspirations (e.g., college education for children), inflation, the formation of a consumption-oriented industrialized society, and most important, the ecnomic shift from manufacturing to service industries that provided jobs with which middle-class women felt comfortable, all contributed to the increased involvement of middleclass women in the market labor (Ferber \& Birnbaum, 1977; Foner, 1979). The labor force participation rate of middle-class females has thus been gradually catching up with their working class counterparts, and a racial convergence in market labor supply was identified (Mott, 1979). 
TABLE II

LABOR FORCE PARTICIPATION RATE OF MARRIED WOMEN SPOUSE PRESENT, THE UNITED STATES

\begin{tabular}{|c|c|c|c|c|}
\hline & & $\begin{array}{l}\text { Female Labor } \mathrm{F} \\
\text { (presence an }\end{array}$ & $\begin{array}{l}\text { articipation } \\
\text { of own childr }\end{array}$ & \\
\hline & Tota1 & $\begin{array}{l}\text { No Own } \\
\text { Children } \\
\text { Under } 18 \\
\text { Years 01d }\end{array}$ & $\begin{array}{l}\text { With Own } \\
\text { Children } \\
6-17 \text { Years } \\
\text { old }\end{array}$ & $\begin{array}{l}\text { With Own } \\
\text { Children } \\
\text { Under } 6 \\
\text { Years 01d }\end{array}$ \\
\hline 1948 & 22.0 & 28.4 & 26.0 & 10.8 \\
\hline 1949 & 22.5 & 28.7 & 27.3 & 11.0 \\
\hline 1950 & 23.8 & 30.3 & 28.3 & 11.9 \\
\hline 1951 & 25.2 & 31.0 & 30.3 & 14.0 \\
\hline 1952 & 25.3 & 30.9 & 31.1 & 13.9 \\
\hline 1953 & 26.3 & 31.2 & 32.2 & 15.5 \\
\hline 1954 & 26.6 & 31.6 & 33.2 & 14.9 \\
\hline 1955 & 27.7 & 32.7 & 34.7 & 16.2 \\
\hline 1956 & 29.0 & 35.3 & 36.6 & 15.9 \\
\hline 1957 & 29.6 & 35.6 & 36.6 & 17.0 \\
\hline 1958 & 30.2 & 35.4 & 37.6 & 18.2 \\
\hline 1959 & 30.9 & 35.2 & 39.8 & 18.7 \\
\hline 1960 & 30.5 & 34.7 & 39.0 & 18.6 \\
\hline 1961 & 32.7 & 37.3 & 41.7 & 20.0 \\
\hline 1962 & 32.7 & 36.1 & 41.8 & 21.3 \\
\hline 1963 & 33.7 & 37.4 & 41.5 & 22.5 \\
\hline 1964 & 34.4 & 37.8 & 43.0 & 22.7 \\
\hline 1965 & 34.7 & 38.3 & 42.7 & 23.2 \\
\hline 1966 & 35.4 & 38.4 & 43.7 & 24.2 \\
\hline
\end{tabular}


TABLE II--Continued

\begin{tabular}{|c|c|c|c|c|}
\hline & Total & $\begin{array}{l}\text { No Own } \\
\text { Children } \\
\text { Under } 18 \\
\text { Years 01d }\end{array}$ & $\begin{array}{l}\text { With Own } \\
\text { Children } \\
6-17 \text { Years } \\
\text { 0ld }\end{array}$ & $\begin{array}{l}\text { With Own } \\
\text { Children } \\
\text { Under } 6 \\
\text { Years Old }\end{array}$ \\
\hline 1967 & 36.8 & 38.9 & 45.0 & 26.5 \\
\hline 1968 & 38.3 & 40.1 & 46.9 & 27.6 \\
\hline 1969 & 39.6 & 41.0 & 48.6 & 28.5 \\
\hline 1970 & 40.8 & 42.2 & 49.2 & 30.3 \\
\hline 1971 & 40.8 & 42.1 & 49.4 & 29.6 \\
\hline 1972 & 41.5 & 42.7 & 50.2 & 30.1 \\
\hline 1973 & 42.2 & 42.8 & 50.1 & 32.7 \\
\hline 1974 & 43.1 & 43.0 & 51.2 & 34.4 \\
\hline 1975 & 44.4 & 43.8 & 52.2 & 36.7 \\
\hline 1976 & 45.1 & 43.7 & 53.6 & 37.5 \\
\hline 1977 & 46.6 & 44.8 & 55.5 & 39.4 \\
\hline 1978 & 47.5 & 44.6 & 57.1 & 41.7 \\
\hline 1979 & 49.3 & 46.6 & 59.0 & 43.3 \\
\hline 1980 & 50.1 & 46.0 & 61.7 & 45.1 \\
\hline 1981 & 51.0 & 46.3 & 62.5 & 47.8 \\
\hline
\end{tabular}

SOURCE: U. S. Department of Labor, Bureau of Labor Statistics, September 1982, Bulleton 2096, Labor Force Statistics Derived From the Current Population Survey: A Databook, vol. I, p. 716, Table C-11. 
So, the trend is now a "fact." It now occurs almost equally among women of all age groups and of every socio-economic class. The question is whether this trend is going to continue. It seems that a simple extrapolation without basic understanding of the interrelationship between affecting factors is too risky in predicting a future trend. We have to take into consideration all the factors mobilizing this trend and study how these factors are going to shape the future pattern of female labor behavior. In Chapter II there will be an in-depth discussion about these factors and about the influence they exert on female labor behavior. 
CHAPTER II

THEORETICAL REVIEW

Traditional models of labor supply assume a dichotomy of time allocation--"work" and "leisure." An individual is supposed to make a decision about substituting income for leisure, as income usually represents an array of consumable goods and services. The time allocated to work is then translated into a labor-supply curve. Two factors are involved in the decision concerning the allocation of time, namely, "the income effect" and "the substitution effect." Since leisure is considered to be a normal good, income change is supposed to have a negative effect on amount of labor supplied, this occurs because a higher income would motivate an individual to consume more leisure and thus have less time left over to work. On the other hand, the substitution effect suggests that, when income is raised, the opportunity cost of leisure becomes higher, and people thus consume less leisure and devote more time to work. So the direction in which an increase in the price of labor (wage rate) will affect the quantity of time devoted to work--i.e., the labor-supply curve--is not determined a priori. If the income effect predominates over the substitution effect, a rise in the market wage rate will reduce the hours of labor supply. Conversely, when the substitution effect overrides the income effect, more time will be spent in the labor market in order to earn the more desirable higher income. Figure 2.1 gives an example of these 
two effects. When the wage rate rises, the budget (or opportunity) line changes from $A B$ to $A C$, and the equilitrium position shifts from $E_{1}$ to $E_{2}$. As a result, the amount of labor supplied by the individual increases from $\mathrm{AQ}_{1}$ to $\mathrm{AQ}_{2}$. This change in quantity results from a substitution effect $Q_{1} Q_{3}$ and an income effect $Q_{3} Q_{2}$. The positive substitution effect is the change in labor supply that the individual would have made with the assumed change in price if his real income had not risen. This effect alone is greater than the total effect. The income effect suggests that the individual with a higher real income will consume more leisure and this in turn will reduce the amount of labor available to the market.

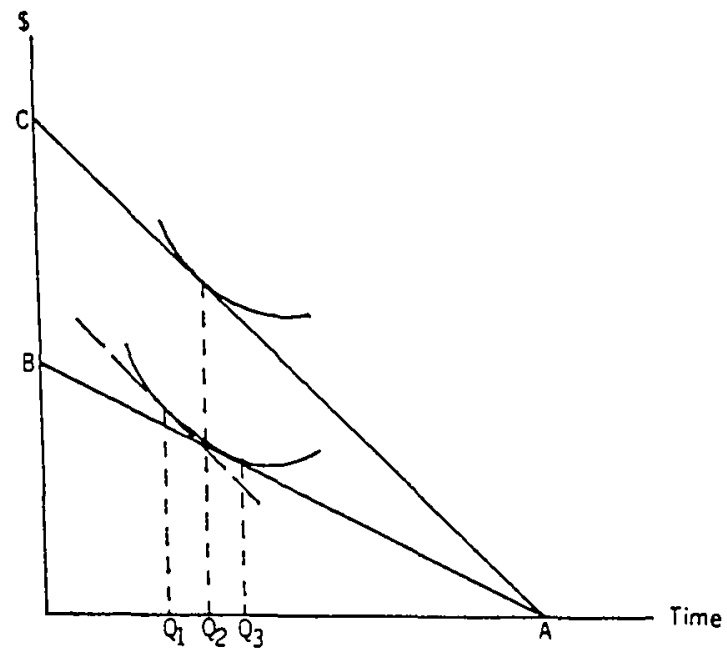

Figure 2.1. The income and substitution effects of the wage rate on an individual's labor supply.

Further theoretical inferences and empirical generalizations suggest, under the law of Marginal Diminishing Return, a backward labor supply curve of an individual, Ceteris Paribus (see Figure 2.2). 


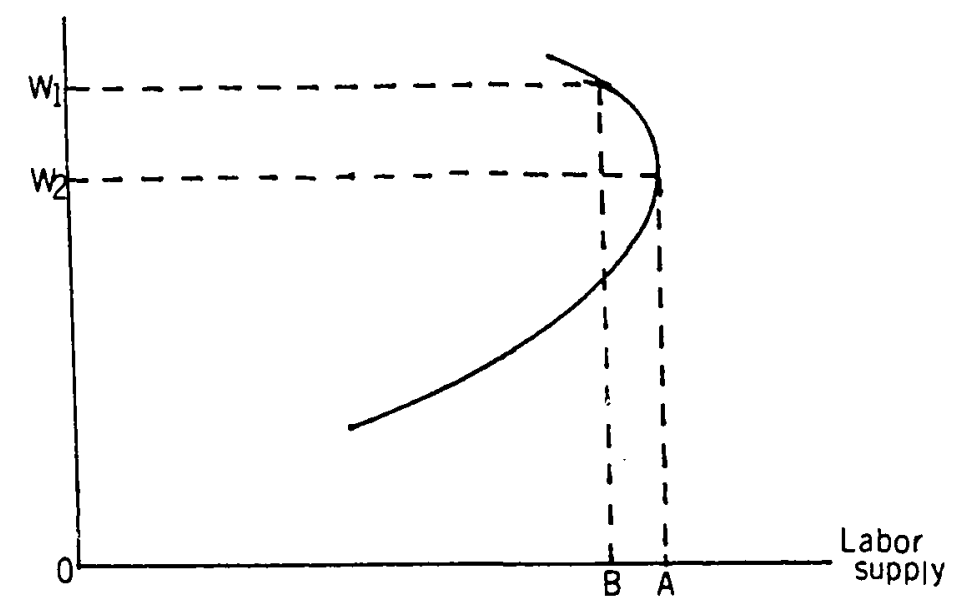

Figure 2.2. An individual's backward-bent labor supply curve.

What is implied by this model is that the substitution effect is stronger than the income effect before a certain point (A). That is, before this point is reached, the wage rate is considered to be relatively low and as a result, the individuals' income tends to be low. Consequently, an increase in the wage rate will inspire the individual to spend more hours working to earn more income in order to be able to purchase goods and services, thereby foregoing leisure time. The result of this is a positively sloped labor supply curve. But there is a backward bend occurring at A. This means that, when the wage rate has been raised to a point higher than the critical one $\left(W_{1}\right)$, the income effect becomes stronger; the labor market activity and the income associated with it is now less desirable than leisure. From the graph above we can see that, as the wage rate increased from $\mathrm{W}_{1}$ (the critical point) to $\mathrm{W}_{2}$, the amount of labor supplied by the individual is reduced from A to B. A negative slope is hence formed. However, the shape of this supply curve (i.e., its slopes and the 
critical wage rate where a backward bend occurs) is a function of the individual's socio-economic characteristics, and of environmental characteristics such as social norms and prevailing economic conditions. The model performs well in explaining the historical trend that suggests a secular negative relationship between the declining length of a working week (although not very significant since the beginning of this century), the declining labor force participation rates of young and old males, and rising real income (Table III).

Resulting from opposition headed by Jacob Mincer (1962), the model has been challenged on its analytical power of understanding female labor behavior. Although the result deriving from crosssectional analysis is consistent with what the model shows--i.e., the higher the family income, the lower the participation rates of the women in the family--time-series analyses give a different story. Closely aligning with the trend of a rising family income, female labor force participation rates and work hours are also rising, especially among married women. To address this problem of conflicting empirical results, it is time for us to go back to review the theoretical basis and assumptions of the model.

Traditional economic analyses have long been criticized as being male-dominated (Sweet, 1973; Glazer, 1976). This field of study is no exception. The model was developed based on the assumption that leisure time and work hours constitute an exclusive dichotomy. This assumption may be applicable in the case of male workers, but it is totally unrealistic as far as women are concerned. First, women are traditionally assigned the responsibility of doing housework, no matter 
TABLE III

MEDIAN FAMILY INCOME, MALE AND FEMALE LABOR FORCE PARTICIPATION RATE, 1947-1981

\begin{tabular}{|c|c|c|c|c|c|c|c|c|}
\hline & \multicolumn{2}{|c|}{$\begin{array}{l}\text { Female Labor } \\
\text { Force Parti- } 1 \\
\text { cipation Rate }\end{array}$} & \multicolumn{2}{|c|}{$\begin{array}{c}\text { Male Labor Force } \\
\text { Participation } \\
\text { Rate }^{2}\end{array}$} & \multicolumn{4}{|c|}{$\begin{array}{l}\text { Median Family } \\
\text { Income (1979 } \\
\text { constant dollars) }\end{array}$} \\
\hline & White & Nonwhite & White & Nonwhite & White & & Nonw & ite \\
\hline & & & & & & $\%^{\star \star}$ & & $\%$ \\
\hline 1947 & 28.7 & 41.0 & 83.2 & 85.3 & 10259 & 50.0 & 5244 & 42.4 \\
\hline 1948 & 30.3 & 39.9 & 83.4 & 83.4 & 9981 & 48.6 & 5331 & 43.1 \\
\hline 1949 & 29.9 & 40.1 & 83.5 & 83.3 & 9841 & 47.9 & 5023 & 40.6 \\
\hline 1950 & 31.1 & 42.1 & 83.3 & 83.5 & 10388 & 50.6 & 5636 & 45.6 \\
\hline 1951 & 31.8 & 41.5 & 83.1 & 82.4 & 10783 & 52.5 & 5679 & 45.9 \\
\hline 1952 & 31.9 & 39.7 & 82.9 & 83.6 & 11250 & 54.8 & 6394 & 51.7 \\
\hline 1953 & 32.3 & 39.6 & 83.0 & 82.9 & 11937 & 58.2 & 6693 & 54.1 \\
\hline 1954 & 33.3 & 46.1 & 85.6 & 84.6 & 11718 & 57.1 & 6509 & 52.7 \\
\hline 1955 & 34.5 & 46.1 & 85.3 & 84.7 & 12505 & 60.9 & 6896 & 55.8 \\
\hline 1956 & 35.7 & 47.3 & 85.5 & 85.1 & 13335 & 65.0 & 7018 & 56.8 \\
\hline 1957 & 35.7 & 47.1 & 85.1 & 84.2 & 13322 & 64.9 & 7128 & 57.7 \\
\hline 1958 & 35.8 & 48.0 & 84.3 & 84.1 & 13305 & 64.8 & 6806 & 55.1 \\
\hline 1959 & 36.0 & 47.6 & 83.7 & 83.5 & 14675 & 71.5 & 7872 & 63.7 \\
\hline 1960 & 36.5 & 48.2 & 83.4 & 83.0 & 14301 & 69.7 & 7917 & 64.1 \\
\hline 1961 & 36.9 & 48.3 & 82.9 & 82.2 & 14511 & 70.7 & 7742 & 62.6 \\
\hline 1962 & 36.8 & 47.9 & 82.1 & 80.8 & 14966 & 72.9 & 7991 & 64.7 \\
\hline 1963 & 37.1 & 48.0 & 81.5 & 80.2 & 15524 & 75.6 & 8215 & 66.5 \\
\hline 1964 & 37.5 & 48.5 & 81.1 & 80.0 & 16048 & 78.2 & 8982 & 72.7 \\
\hline
\end{tabular}


TABLE III--Continued

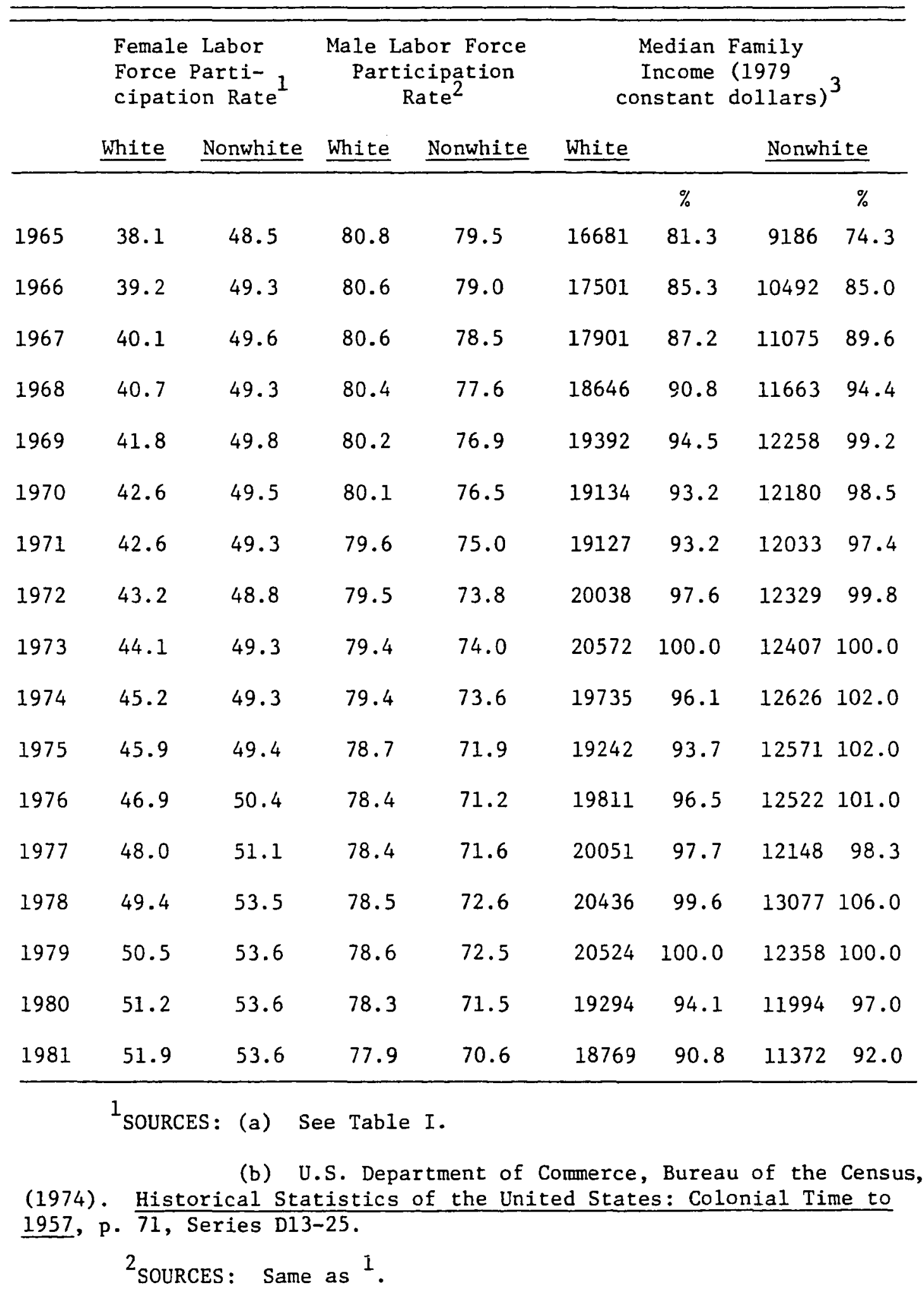


TABLE III-- Continued

${ }^{3}$ SOURCE: U.S. Department of Labor, Bureau of the Census, (1979), Current Population Reports, Special Studies Series P-23, No. 80, The Social and Economic Status of the Black Population in the United States: A Historical Review 1790-1978, p. 31, Table 14.

U.S. Department of Labor, Bureau of the Census, Statistical Abstract of the United States 1980, p. 451, Table 745.

U.S. Department of Commerce, Bureau of the Census, Statistical Abstract of the United States 1984, p. 463, Table 763.

$\star *$ Base Year: $1979=100.0$

whether they hold a market job or not (Laws, 1971; Boskin, 1974; Kreps \& Leaper, 1976; Nelson, 1980). It is essential for them to decide how to allocate their time among leisure, market work, and housework. For this reason, the appropriate decision-making unit should be a family rather than an individual generally recognized in the traditional model (Mincer, 1962). The traditional approach which ignores what is taking place within the household is obviously somewhat deficient. On the other hand, the aggregation of housework and leisure into one entity in the traditional approach is valid only when it is assumed that these two elements form composite goods with their relative price held constant in spite of environmental changes (Gronau, 1977). This assumption does not seem realistic either. It is evident in this case that we need a new conceptual framework which will improve the theoretical treatment of female labor behavior. In response to this need, a new approach--the "New Home Economics"--has evolved since the early sixties. 
THE "NEW HOME ECONOMICS" APPROACH

The New Home Economics differs from the traditional theory of consumer behavior in its postulation that a household is not only a consumption unit but also a place of production--a household purchases market goods and services and combines them with time to produce "commodities." These commodities, in contrast to the market goods in the traditional theory, are the immediate sources of household utility (Becker, 1965). According to this view, every commodity has an implicit price attached to it which includes two components: namely, the monetary costs of any market goods involved and the time used by the household to produce the commodity. This approach can be applied to a wide range of problems. For example, the "quality of children" can be viewed as a commodity produced by combining market goods and parental time (Willis, 1974). Also, "human capital" is a commodity with goods (e.g., tuition, stationaries, etc.) and time spent in school attendance all serve as input factors (Becker, 1962; Mincer \& Polachek, 1974). While Becker emphasized the role of time as a scarce resource for household utility maximization, Lancaster (1966) paid more attention to the nature of the household production process. The "characteristics" mentioned by Lancaster can be viewed as identical to the "commodities" in Becker's framework. According to Lancaster, each kind of goods poses a vector of characteristics which is the direct source of utility. So, eating a steak satisfies our needs in terms of the vitamins and calories it contains, by its ability to vanquish our hunger pangs, and by its other "characteristics." 
Within the theoretical framework of this new approach, it is the household joint utility that is at issue. Income and other resources are pooled and then allocated to achieve utility maximization. That is, every household member is not only a consumer but also a producer and, given the household production function, household members organize their limited resources (income and time) to maximize the output of commodities. Since these commodities are the direct sources of utility, maximizing commodity output is the same as achieving utility maximization. The basic assumption is that every individual household member's utility is optimized only when the household joint utility is maximized. Since the household may be viewed as a place where the costs and benefits associated with various alternatives are evaluated and decisions are made, when women face a choice between leisure, work and home, and work in the market, three effective processes are relevant: the substitution between household members, housework and market goods, and between market goods and time. A detailed examination of these substitution effects is necessary in order to gain a full understanding of women's labor and commuting decisions.

The Substitution Between Housework and Market Goods (or Services)

If we view the household as a production unit, resource allocation is achieved by evaluating the relative prices of input factors (including labor) with respect to the price of output commodities. To do this, whenever a labor decision is to be made, women must first impute some value to housework. The value of domestic service is 
determined by two factors--home skills (productivity) and family preference (or the family's demand for these services).

A most significant factor that affects the need for women's domestic service in the family is the so-called "child effect." This effect is determined by two factors: the number of children and the ages of the children. Most empirical studies have found that the presence of children in the household has a strong negative effect (e.g., Mincer, 1963; Lglehart, 1979; Lehrer \& Nerlove, 1980;

Oppenheimer, 1982). The explanation is straightforward. More children means that the family needs more childcare and a higher value is thus put on a mother's tasks at home. The result is a negative effect on the female market labor supply. On the other hand, the age of the children is even more significant in its influence on women's labor behavior. Empirical findings suggest a positive relationship between the female labor force supply and the age of the children involved (Kreps \& Leaper, 1976; Lglehart, 1979). This is understandable since younger children need more intensive care and thus place a higher demand on a mother's time. As the children get older, the time demand made on their mothers will ease off but the monetary expenditure will increase and a household's demands will shift from time-intensive to goods-intensive commodities. In this situation, women are more likely to devote their time to working in the market since the value of their domestic services is reduced and the need for monetary income, which must be earned from the market, is increased. Some literature suggests that the spacing of births has a significant effect on women's labor behavior since the costs incurred by children depend on how closely 
they are spaced (Moore \& Sawhill, 1976). But in terms of a crosssectional analysis as reported here, the effect of the "spacing" implies an interaction effect of the "number" effect and the "age" effect.

Proposition 2.1. The amount of a woman's time demanded by the household is a function of the "child effect"--i.e., the number and age composition of children in the household.

Proposition 2.2. The amount of time a woman is willing to devote to market work is a function of the "child effect."

Other housework such as housing maintenance, laundry, mowing the lawn, etc. also has a value attached to it (by the household as a whole). The valuation of these services is much more straight forward in comparison with that of childcare. Market substitutes for these services are readily available at certain prices.

Proposition 2.3. The amount of a woman's time demanded by the household is a function of the amount of housework to be done, which may be approximated by the amount of household housing consumption. However, the amount of time devoted to housework by a female household member is decided not only by household demand for domestic service but also by her home productivity. While education would increase both market and home productivity (Michael, 1972; Heckman, 1974), more educated women would be able to spend less time doing the same amount of housework, Ceteris Paribus.

Proposition 2.4. The amount of a woman's time spent on domestic services is a function of her educational level or the human capital investment made. 
Women facing the alternatives of housework and market work must make a choice by evaluating the costs and benefits associated with these alternatives. If a woman decides to spend her time on domestic services, she then suffers the cost of losing income from market labor. So, the woman evaluates the two alternatives by comparing her market earning ability with the value of her domestic service. A worker's income or potential income is decided by his or her human capital investment. Empirical findings all suggest that better-educated women have higher labor force participation rates, Ceteris Paribus (Bowen \& Finegan, 1969; Orden \& Bradburn, 1969; Sweet, 1973). That is, to the extent that education or schooling contributes more to the productivity of time in the labor market than to that of time at home (Leibowitz, 1974), higher-educated women tend to choose labor because the value of their income from market work is likely to exceed that of their domestic work.

Proposition 2.5. The amount of time a woman is willing to devote to domestic service is a function of her income earning ability. This ability, according to the human capital investment theory, is decided by her educational level, working experience, on-the-job training, etc.

When women decide between alternatives, it is not only the value of their domestic work and the value of market work (to the family) which matter. It follows that, if women decide to work in the market, they have to "buy" substitutes from the market to do the housework which is originally their responsibility. So the prices of these market goods must be taken into consideration when they make their 
choice. That is, if women decide to work in the market, their income must be high enough to cover the expense of buying these goods from the market. The extent of substitution between home goods and market goods varies. For example, infant care is much less substitutable than a meal or laundry work. But, in other words, different levels of substitution only means that different prices are attached to them; that is, the less substitutable goods have higher market prices and vice versa (Stolzenberg \& Waite, 1984).

Proposition 2.6. The amount of time a woman is able to work outside the home is a function of the market prices or the availability of the market substitutes of the housework.

The Substitution Between Household Members

When women face making choices in terms of their labor behavior, the substitution between home goods and market goods is not the only criterion for judgement. One possibility which should be considered is the delegation of housework to other members (e.g., husbands or grown-up children) of the household whose (potential) market income is not only lower than the woman in the family but is too low to pay for market substitutes. According to the household production theory, the achievement of a household equilibrium condition necessitates the ratio of the marginal productivity of given individuals to be equal to the ratio of the prices of goods or services to the (potential) wage rates of houseliold members, or to the value of the housework done by the individual. So, if a household member's market wage is lower than that of other members and also lower than the market price 
of housework, then he (or she) should be assigned housework until the value attached to his (or her) domestic service is equal to the market price. Consequently, the low-wage earner(s) in the household would allocate less time to market labor and more time to housework (Becker, 1965; Berk, 1980).

Empirical studies have consistently shown that the division of labor in the family remains essentially unchanged when women are more and more involved in market labor (Walker \& Gauger, 1973; Robinson, 1977). This means that most women who take market jobs continue to be responsible for most domestic work (Glazer, 1980); Vanek, 1980). On the one hand, this can be partially explained by the lower relative productivity of women in the market to that of men (Lehrer \& Nerlove, 1980). On the other hand, this is a matter of the family's taste or preference which may be attributed to prevailing social norms. A perfect substitution between partners implies a companionate type of marriage. It is recognized that we are, although developing in this direction, still far from achieving this kind of relationship (Matthaei, 1980). However, the substitution is in operation (at least within a certain range) and should be taken into account in studying women's labor behavior. Based on the well-established phenomenon that husbands and wives tend to be similar with respect to age, race, education, and religion (Sawhill, 1977); and in recognition of the fact that peoples' attitudes toward sex-assigned roles are changing (Matthaei, 1980), this effect is tending to get stronger and stronger. 
Proposition 2.7. The division of housework responsibility among household members is a function of their market income-earning abilities, so the amount of time a female household member allocates to market work is affected by her partner's (potential) income or wage rate.

\section{The Substitution Between Time (Space) and Goods}

Empirical studies suggest that, when the distance traveled is included as an explanatory variable for the wage rate, a positive effect can usually be found (Moses \& Williamson, 1967; Orr, 1975). That means, the farther the worker has to travel, the higher his (or her) wage rate is supposed to be. This explains why female workers commute shorter distances than male workers in general (Fox, 1983). It conflicts with the argument that, at equilibrium, the marginal value of time should be equal to the wage rate and women with a lower wage rate should then travel for a longer time as the opportunity cost of their travel time is lower (White, 1977). A possible explanation of the problem is based on the recognition of the substitution between time and goods. Citing Becker's (1965) example: when a person wants to buy a gallon of milk, he can drive to a supermarket and pick up what he needs there, or he can have the milk delivered to his home--by doing this, he spends less time but consumes the goods at a higher price. A choice between the two alternatives should be made depending on the individual's marginal value of time. If his (or her) marginal value of time is higher than the additional cost incurred by delivery, the individual will choose to consume the delivered milk. If we apply the same rationale to explain the relationship between commuting behavior and wage rate, commuting time and the amount of labor supply 
now become input factors in generating income. In this sense, the time spent in commuting and the time spent in work may be either substitutable or complementary, as theoretically and empirically suggested by Madden (1977) and Kasper (1983). An extreme case is that the two time elements are "perceived" as being the same. So people are willing to travel longer distances only when a higher wage is available. To give an example: suppose there are two full-time jobs (i.e., eight hours each day) available to a person, one with a wage rate ten dollars an hour and the other nine dollars per hour and the person has to spend two hours conmuting each day if he chooses job 1 but spends no time at all commuting to job 2 since the job is located right next door. Obviously this person will "perceive" the real wage rate of job 1 as $(10 \times 8) /(8+2)=$ eight dollars an hour according to the assumption that commuting time and work time are perfectly substitutable. This real wage rate is now lower than that obtainable from job 2, so job 2 will be selected. Suppose now that the value of this person's home service is worth ten dollars an hour to the household, then the individual will choose neither job 1 nor job 2 but choose to stay at home to provide domestic service. To summarize, the prevailing lower wage rates of female workers means that they are less willing to commute for a longer distance; and the high valuation of their home service means they are less able to work at a low "real" wage rate because in this situation they are "preferred" to stay at home by a household joint decision. It is thus reasonable to infer that both the value of commuting time and the value of working time should be lower than the measured wage rate. Some transport studies estimating the value of 
measured wage rate. Some transport studies estimating the value of commuting time lend support to this argument (Beesley, 1965; Quarmby, 1967). Still, the validity of the assumption about the substitution or complementariness between commuting and working time should be empirically evaluated. If we combine this argument with Goldner's (1955) suggestion that firms or employers are liable to pay the premium to attract workers from distant areas because there are other factors more influential than the distance to work in deciding residential location, we can derive the following proposition:

Proposition 2.8. The amount of market labor supply and the commuting distance of a female household member are simultaneously determined; and they are both affected by the differential wage rates offered to her at different locations in space.

THE PERMANENT INCOME THEORY

Measuring the effect of income has always been a problem in most researchers of consumer behavior. Here, the permanent income theory, first proposed by Friedman (1957), serves to help us in resolving this problem.

In the General Theory, Keynes argued that current consumption behavior is a highly stable function of current income. But empirical studies did not convincingly support this assertion. The inadequacy of this simple theory of income effect has been noticed. William Hamburger (1955) suggested that consumption behavior be viewed as a function not only of income but also of wealth. Putting it in an equation for empirical studies, it is formulated that the average 
propensity to consume is directly dependent upon the ratio of wealth to income--the "Pigou effect" (Pigou, 1943). Friedman (1957) incorporates the wealth-inrome effect by proposing the "permanent income hypothesis" in which income is decomposed into two elements: a permanent component and a transitory component. In other words, because people's consumption behavior or level of expenditure is decided by their long-term expectation of income, it is thus the permanent component that is relevant to consumption decisions. In essence, the permanent component of income is in concept the same as the potential eaming capability or average life-time value. This life-time expectation or earning capacity is mainly a function of human capital investments which include education (schooling) age, or experience. Empirical findings have shown a positive relationship between education level and earning ability (Rima, 1981), and between education level and labor force participation (Orden \& Bradburn, 1969; Sweet, 1973). Of course, the theory of human capital investment does postulate a higher income as a return to the investment being made. And as has been previously mentioned, to the extent that the effect of education and training is greater on increasing market productivity than its contribution to non-market productivity, a positive relationship between education and market labor force participation can be expected. Another source of the permanent component of income comes from the non-human wealth a household possesses. This may include inheritances, rental income, income gained from stockholdings, interest, etc. It is widely recognized that human and non-human wealth will exert differential influences on household consumption (Friedman, 
1957; Becker, 1965). Rosett (1958) found that property income had a significant negative effect on women's market labor supply. This may be explained by the fact that households having rental income usually place a higher value on housework (which may include financial management and maintenance work of the rented properties) and which overrides the income women can earn from market jobs.

On the other hand, the transitory component of income, which has an accidental or chance occurrence, does not raise the anticipation of further income from the same source. So it is not supposed to affect the consumer's behavior or the demand for commodities because its occurrence will not change people's expectation of their life-time (average) income.

Proposition 2.9. People's market behavior--including their labor behavior--is a function of their permanent or expected income.

Proposition 2.10. According to the theory of human capital investment, permanent or expected income is a function of educational level, experience, age, etc.

\section{THE MARKET CONDITION}

We have so far discussed the factors affecting the labor supply decision of a female household member. However, the household is not an isolated institution, and most of the time, it acts as an adaptive unit responding to a variety of constraining opportunities imposed by the outside environment. From a close observation of the historical pattern of women's labor behavior (as has been discussed in Chapter I), we can see that the female labor force usually functions as a reserve 
of labor entering (e.g., during the war period) and leaving (e.g., after the war--1950's) the labor force in correspondence with the demand of the economy (Gubbels, 1968; Benston, 1969). Oppenheimer (1970) even contended that the demand for female labor is more important than the supply factors in determining women's labor behavior. Furthermore, Barrett (1976) argued that the existing demand conditions would affect peoples' attitudes towards women's labor behavior. So the idea of a woman as a "housewife" which prevailed in the 1950's, according to him, may be attributed to the return of the war veterans. The attitude that women do not need jobs as much as men disappears when more labor is demanded in keeping with economic development and revives during periods of economic recession. If they are explained in this way, domestic services will be accorded a higher social value during a period of slow growth than during one of more rapid growth.

There are two possible effects incurred by changes in the labor market demand. The effects are both theoretically sound but act in oppostie directions

The Added-Worker Effect

According to the permanent income theory, family income consists of four elements: (1) the permanent income of the household head; (2) the household head's transitory income; (3) the permanent income of other members in the family; (4) other members' transitory income. Here the permanent income from other household members other than that of the household head depends on the expected degree of permanence of their attachment to the labor force. With regard to 
this definition, Mincer (1960) argued that, perceived by the household as a whole, women's income was largely transitory in nature; that is, female workers in most families were secondary income earners. This postulate was agreed upon and employed by Duker (1970) in studying the difference in housing consumption between one- and two-earner families. To the extent this claim still holds true--in fact, there were more and more female-headed families in the seventies--the permanent income theory suggests that demand variations resulting from economic cycles are more likely to induce temporal variations in women's labor behavior in that the household consumption pattern is sustained (Amsden, 1980). Some past empirical studies have supported the existence of this effect. For example, in 1949 employment rates for wives whose husbands were unemployed were higher than those whose husbands were fully employed (Cain, 1966). Also, a negative association has been found between the proportion of family income contributed by other members, wives in particular, and the main earner's working status (Mincer, 1960). That is, if the household head's labor is under-utilized and his income is thus reduced as a result of an economic downward trend, then the marginal value of the money income to the household is increased and the transitory income from secondary worker(s) in the household is preferred to offset the negative impact of the prevailing economic conditions on the household. More specifically, Barrett (1976) proposed evidence that women who would not have worked in ordinary times entered the labor dorce during a period of high inflation when the family's or the household head's real income was lowered. On the other hand, 
to the extent that uncertainty is related to inflation and employment, household consumption behavior will be affected by current economic conditions (Boskin, 1974), and the women's labor behavior will thus be indirectly affected. This argument is partly supported by the empirical finding that housing consumption is inversely related to the probability of unemployment (Desalvo and Eeckhoudt, 1982). To sum up, the point here is that the transitory fluctuation of family income, resulting from the environment or macro-demand conditions, may significantly affect female labor behavior-especially when women are in general recognized as secondary workers in the household.

\section{The Discouraged-Work Effect}

Time-series analyses of the impact of an economic recession have consistently found that, since 1948, female unemployment rates have exceeded those of the male and that the differentials have been at their greatest at business cycle peaks. Since frictional unemployment is more likely to happen to those women who frequently move back and forth between non-market and market work (Mincer, 1960; Mincer, 1966; Hall, 1970), it has been inferred that a lower differential between unemployment rates of the male and female can be attributed to the fact that a higher proportion of (the original) female workers have been discouraged and have dropped out of labor market and thus are not captured in the unemployment statistics (Sweet, 1971; Niemi, 1974). Females are more likely to be discouraged because in the first place, the last in, first-out seniority policy 
exercised by most employers makes the employment prospect of women less hopeful in difficult economic conditions (Chiplin \& Sloave, 1974); and second, when the expected gain from the labor force participation drops because of an economic recession or continued high unemployment (or underemployment) rate, women will shift to the relatively higher-valued domestic work which is traditionally their work area.

It is not very clear which one of the two opposing effects will predominate over the other during a demand change. Hansen (1961) studied this issue using data of 1954-1959 and found that the labor force did not increase even when the level of unemployment increased during this period. Subsequent studies done by Mincer (1966) and Bowen and Finegan $(1965 ; 1969)$ consistently concluded that, while other factors (e.g., age, race, etc.) were controlled, some additional workers entered the labor force during the recessions but more workers dropped out of the labor force. Although all this evidence suggests that the discouraged-worker effect is predominant over the added-worker effect, it remains uncertain whether these previous experiences will duplicate themselves today or in the future. The reason for this is that the economic development during the periods covered by these studies was pretty steady and the recessions were mild, compared with current and prospective economic conditions. Proposition 2.11. The demand conditions of the labor market has a significant effect on women's labor behavior. 
MARKET SEGMENTATION

Market segmenting is necessary whenever we deal with a population which is not homogeneous with respect to the subject studied. The basic rationale is that people in different segments will face different opportunities or constraints, or that they will behave differently in response to the same environmental stimuli. In terms of women's labor behavior, it means that all the economic factors we have so far discussed would have differential influences on the household's allocation of time among market work, housework, leisure, and the cross-substitution among household members. Here, two possible criteria for segmentation, partly concept-oriented and partly methodology-oriented, in relation to female labor and commuting behavior are proposed.

Occupations

Education (or schooling), experience, and other forms of human capital investment have been suggested in this study as instrumental variables used to derive the permanent component of an individual's real income. Even if education by definition has a much broader sense than monetary earning (e.g., education level usually determines work commitment attitude), the fact that individuals with different levels of education may possess jobs of the same monetary income indicates that, as long as we cannot include a qualitative indicator (e.g., the "major" of a student) in education measurement, we are handicapped by the inability to pick up some non-pecuniary (permanent) income gains in the form of lighter or more pleasant work. 
The importance of mental satisfaction of work is popularly recognized (e.g., Caplow, 1954; Kahn, 1972). Occupation has thus been suggested by soiologists as a major determinant of one's social position (status) in a society. On the other hand, there are substantial differences between certain occupations in their comparative vulnerability to economic cycles. For example, blue-collar workers have much higher unemployment rates than white-collar workers, especially in times of an economic trough (Oppenheimer, 1982). Also, theories of the labor market structure support the approach of segregation by occupations. When the labor market is assumed to be perfectly competitive, the forces of competition operate to produce the optimum allocation of labor resources and the state of marginal equalities will be achieved. According to this argument, an "open" (frictionless) job market for all workers will exist (Doeringer, 1967; Rubery, 1978) and workers equalize net benefits between different occupations. But recently it has been widely admitted that the theory of dual labor markets (Reich, Gordon \& Edwards, 1973) may be more realistic in describing the real world. Dual labor markets arise as a result of the interaction between the changing economic structure, technological advancements, and the pattern of labor market behavior. The dual labor market theory stresses that, as a result of the changing nature of production and technology, firms are willing to sacrifice some flexibility for stability of the labor force they need. Since these firms are usually oligopolists with some price-controlling power, the "internal" workers employed in these firms can get higher wages, better prospects 
of promotion, and security of employment. For those workers in the "residual" sector the wages are low, employment is insecure, and skill or on-the-job training is not needed because only stagnant technologies are employed in this sector. At the same time, institutional factors (e.g., unionization) have differential influences on the two sectors. The two sectors may co-exist within a firm, the internal workers and residual workers co-existing and being differentially treated by the employer. A critical difference is that, when experience or seniority is the most important factor in deciding the productivity and wage rates of the internal workers, there is an absence of relationship between earnings and length of service for those residual workers. As a result, Clack Keer (1954) argued that the existence of structural institutional factors--especially unionization--creates substantial differences in labor market opportunities.

So, a grouping by occupations which, borrowed from Alfreda Lglehart (1979) and being consistent with the census occupational classification system, may help us divide population into homogeneous "segments."

1. Labor, service worker;

2. Crafts, operatives;

3. Clerica1, sales;

4. Professional, manager.

Proposition 2.12. The labor market is likely to be segmented by occupations. 


\section{Ethnic Background}

It has been widely recognized that work attitudes of black women reveal a completely different pattern from that of white women. Ladner (1972) argues that their cultural heritage leads black women to be more aggressive, independent, and morally loose. One of the results is that the rate of employment of black women has been historically much higher than their white counterparts, although the trend has been reversing in recent years. Also, the greater uncertainty associated with higher divorce rates among black families, which is attributed more to cultural than to economic factors, makes black women devote more time to market labor because, in terms of the permanent income theory, they possess a smaller amount of permanent income in comparison with the white women of the same income level (Cain, 1966; Sweet, 1973). Another example worth mentioning is that children are perceived differently as either "producer durables" (i.e., able to produce a stream of future income for their parents, perhaps when the parents are old and retired), or as "consumer durables" (i.e., able to produce a stream of subsequent satisfactions for the parents as does an automobile or a house) among different ethnic groups (Sawhill, 1977). It is obvious that people with these two different points of view will have various fertility and labor behavior (e.g., Cramer, 1973). Although a significant income effect is involved, cultural norms (or cultural backgrounds) are most of the time recommended to explain the origins of these different perceptions. Table IV shows the differential effect of children on women's labor behavior: the labor force participation rates of black 
women have been higher than those of white women even though their birth rates have also been higher.

A final point is the effect of discrimination. Empirical evidence suggests, directly and indirectly, that discrimination between those of color does exist in the J.abor market (e.g., Baker \& Levenson, 1975; Levinson, 1975). Glazer (1980) further argued that one of the factors contributing to the higher employment level of minority wives was the income effect of discrimination against minority men. Discrimination also exists in other markets which affect women's labor behavior. For example, though not rigidly identifiable, most theorists of urban economics and housing experts agree that discrimination exists in the urban housing market (Heilbrun, 1981). The resulting higher price of housing will produce an income effect which in turn encourages more market work and, more significantly, a substitution effect which brings about a shift from housing goods to other market goods, for the group(s) being discriminated against. Also, all the theories of the community spatial structure (e.g., the concentric theory, the sectoral theory, the multi-nuclei theory) suggest a pattern of residential segregation. Besides the effect of income and social symobolization, ethnic affiliation is a significant factor contributing to the segregation pattern. Some forces combine to affect the value of ethnic affiliation. Discrimination is obviously one of them. This racial effect on the location pattern may result in different commuting behavior which the structural factors so far mentioned do not explain. To summarize, a market segmented by "ethnic groups" may help reduce some noises affecting the performance of the factors in the model. 
TABLE IV

FEMALE LABOR FORCE PARTICIPATION RATE AND BIRTH RATE, BY COLOR

\begin{tabular}{|c|c|c|c|c|c|c|}
\hline & \multicolumn{3}{|c|}{$\begin{array}{l}\text { Female Labor Force } \\
\text { Participation Rate }\end{array}$} & \multicolumn{3}{|c|}{ Crude Birth Rate ${ }^{2}$} \\
\hline & Total & White & Nonwhite & Total & White & Nonwhite \\
\hline 1900 & 20.0 & 17.3 & 41.2 & 32.3 & 30.1 & $\mathrm{~N} / \mathrm{A}$ \\
\hline 1910 & $\mathrm{~N} / \mathrm{A}$ & $\mathrm{N} / \mathrm{A}$ & $\mathrm{N} / \mathrm{A}$ & 30.1 & 29.2 & $\mathrm{~N} / \mathrm{A}$ \\
\hline 1920 & 22.7 & 20.7 & 40.6 & 27.7 & 26.9 & 23.5 \\
\hline 1930 & 23.6 & 21.8 & 40.4 & 21.3 & 20.6 & 27.5 \\
\hline 1935 & $\mathrm{~N} / \mathrm{A}$ & $\mathrm{N} / \mathrm{A}$ & $\mathrm{N} / \mathrm{A}$ & 18.7 & 17.9 & 25.8 \\
\hline 1940 & 25.7 & 24.5 & 37.3 & 19.4 & 18.6 & 26.7 \\
\hline 1945 & 35.9 & N/A & $\mathrm{N} / \mathrm{A}$ & 20.4 & 19.7 & 26.5 \\
\hline 1946 & 31.1 & $\mathrm{~N} / \mathrm{A}$ & N/A & 24.1 & 23.6 & 28.4 \\
\hline 1947 & 30.8 & 28.7 & 41.0 & 26.6 & 26.1 & 31.2 \\
\hline 1948 & 32.7 & 30.3 & 39.9 & 24.9 & 24.0 & 32.4 \\
\hline 1949 & 33.1 & 29.9 & 40.1 & 24.5 & 23.6 & 33.0 \\
\hline 1950 & 33.9 & 31.1 & 42.1 & 24.1 & 23.0 & 33.3 \\
\hline 1951 & 34.6 & 31.8 & 41.5 & 24.9 & 23.9 & 33.8 \\
\hline 1952 & 34.7 & 31.9 & 39.7 & 25.1 & 24.1 & 33.6 \\
\hline 1953 & 34.4 & 32.3 & 39.6 & 25.0 & 24.0 & 34.1 \\
\hline 1954 & 34.6 & 33.3 & 46.1 & 25.3 & 24.2 & 34.9 \\
\hline 1955 & 35.7 & 34.5 & 46.1 & 25.0 & 23.8 & 34.7 \\
\hline$i 956$ & 36.9 & 35.7 & 47.3 & 25.2 & 24.0 & 35.4 \\
\hline 1957 & 36.9 & 35.7 & 47.1 & 25.3 & 24.0 & 35.3 \\
\hline 1958 & 37.1 & 35.8 & 48.0 & 24.3 & 23.3 & 34.3 \\
\hline
\end{tabular}


TABLE IV--Continued

\begin{tabular}{|c|c|c|c|c|c|c|}
\hline & \multicolumn{3}{|c|}{$\begin{array}{l}\text { Female Labor Force } \\
\text { Participation Rate }\end{array}$} & \multicolumn{3}{|c|}{ Crude Birth Rate ${ }^{2}$} \\
\hline & Total & White & Nonwhite & Total & White & Nonwhite \\
\hline 1959 & 37.1 & 36.0 & 47.6 & 24.0 & 23.1 & 34.2 \\
\hline 1960 & 37.7 & 36.5 & 48.2 & 23.7 & 22.7 & 32.1 \\
\hline 1961 & 38.1 & 36.9 & 48.3 & 22.4 & 22.2 & 31.6 \\
\hline 1962 & 37.9 & 36.8 & 47.9 & 21.7 & 21.4 & 30.5 \\
\hline 1963 & 38.3 & 37.1 & 48.0 & 21.6 & 20.7 & 29.7 \\
\hline 1964 & 38.7 & 37.5 & 48.5 & 21.0 & 20.0 & 29.1 \\
\hline 1965 & 39.3 & 38.1 & 48.5 & 19.3 & 18.3 & 27.6 \\
\hline 1966 & 40.3 & 39.2 & 49.3 & 19.4 & 17.4 & 26.1 \\
\hline 1967 & 41.1 & 40.1 & 49.6 & 18.4 & 16.8 & 25.0 \\
\hline 1968 & 41.6 & 40.7 & 49.3 & 17.8 & 16.6 & 24.2 \\
\hline 1969 & 42.7 & 41.8 & 49.8 & 17.5 & 16.9 & 24.4 \\
\hline 1970 & 43.3 & 42.6 & 49.5 & 17.8 & 17.4 & 25.1 \\
\hline 1971 & 43.3 & 42.6 & 49.3 & 18.4 & 16.2 & 24.7 \\
\hline 1972 & 43.9 & 43.2 & 48.8 & 17.2 & 14.6 & 22.9 \\
\hline 1973 & 44.7 & 44.1 & 49.3 & 15.6 & 13.9 & 21.9 \\
\hline 1974 & 45.6 & 45.2 & 49.3 & 14.8 & 13.9 & 21.2 \\
\hline 1975 & 46.3 & 45.9 & 49.4 & 14.8 & 13.6 & 21.0 \\
\hline 1976 & 47.3 & 46.9 & 50.4 & 14.6 & 13.6 & 20.8 \\
\hline 1977 & 48.4 & 48.0 & 51.1 & 14.6 & 14.1 & 21.6 \\
\hline 1978 & 50.0 & 49.4 & 53.5 & 15.1 & 14.0 & 21.6 \\
\hline 1979 & 51.0 & 50.5 & 53.6 & 15.0 & 14.5 & 22.2 \\
\hline 1980 & 51.5 & 51.2 & 53.6 & 15.6 & 14.9 & 22.5 \\
\hline 1981 & 52.1 & 51.9 & 53.6 & 15.9 & $\mathrm{~N} / \mathrm{A}$ & $\mathrm{N} / \mathrm{A}$ \\
\hline
\end{tabular}


TABLE IV-- Continued

${ }^{1}$ SOURCE: See Table I.

2 SOURCE: (a) U.S. Department of Commerce, Bureau of the Census, (1974), Historical Statistics of the United States: Colonial Time to 1957, p. 23, Series B19-36.

(b) U.S. Department of Commerce, Bureau of the Census, Statistical Abstract of the United States 1984, p. 64, Table 851; 1980: p. 62, Table 88; 1977: p. 55, Table 75; 1975: p. 53, Table 68; 1974: p. 53, Table 68; 1972: p. 50, Table 62; 1969: p. 47, Table 54; 1963: p. 52, Table 49.

Proposition 2.13. People of different ethnic groups behave differently in response to the determinants of labor and commuting behavior.

\section{A SOCIOLOGICAL SUPPLEMENT}

In economic analysis, people's preferences are assumed to be determined by factors (e.g., cultural, biological, demographic, or sociological) outside the framework of the economic discipline (MacRae, 1976). This serves as the basic rationale for the necessity of market segmentation in the analysis reported here. On the other hand, employing a joint household utility function assumes that household members have "given" preferences which make them care enough about each other to consider these every time they make decisions. So an individual member's utility is at least optimal when household utility is maximized. But, as implied by the trend of rising divorce rates, the marriage relationship sometimes breeds tension or negative caring among the participating members. This suggests the importance 
of considering the individual's utility and the interaction of the household members' utilities (Ferber \& Birnbaum, 1977). While the "given" preference is reflected by the parameters empirically derived in the model, the introduction of cther affecting variable(s) into the model should help to eliminate the systematic component of the error term. A more unbiased estimation can thus be secured.

The traditional economic approach assumes that, at the time of their marriage, a couple plans the number of children they are going to have, the labor division, the amount of human capital investment in household members, and their participation in other activities in order to maximize household (life-time) utilities. Besides the problem of imperfect information which might draw decision-making from a utility-maximizing process, the historical development pattern clearly shows that people have to periodically reconsider their utility-maximizing behavior as a result of their changing aspirations or a change of environment. In terms of the research interest here, changes in attitude towards female labor behavior have been identified by several empirical studies (e.g., Duncan \& Duncan, 1978; Lglehart, 1979; Oppenheimer, 1982). Since this dynamic characteristic of peoples' attitudes (or preferences) may hardly be captured in a static economic study such as this, the "reference group theory" is incorporated here to help us study an important underlying mechanism motivating the changes in attitude towards (women's) market labor.

Festinger (1954) proposed that, on the individual level, people will compare their opinions and abilities with others who are similar to themselves. These people with similar characteristics form the 
reference group(s) of the individual. The positive feeling of doing the correct thing and the evaluation of one's performance through this comparing process become a source of satisfaction. In other words, people's value system is built upon this comparison mechanism. The concept was further elaborated by Merton (1957) who integrated within the theoretical framework the hypothesis that a number of reference groups rather than just one may be influential in the evaluation of one's own position; and that reference groups may provide negative as well as positive standards of comparison. Here, the theory is used to explain the changes in women's labor behavior. In earlier times, operating norms dictated that home was the primary workplace for women, and housekeeping and mothering were the only careers that women should pursue. A basic assumption behind this norm is that it was impossible for women to adequately perform domestic services while possessing a job in the labor market. So working wives who tried to combine a home career with a job career were caught between two reference groups with conflicting evaluation standards--a work reference group and a family reference group (Darley, 1976). As a result of this, tension and insecurity induced by the inability to cope with both groups have tended to discourage women from entering the job market. However, in these circumstances, working women can still get credit for their labor behavior if the reason why they are working outside the home is to help meet some household needs. In this case, a woman's labor behavior is consistent with her traditional role as a helpmate to the family (Chafe, 1976). It is based on this arguement that the effect of an economic depression 
on women's labor force participation can be explained. That is, during a depression, extra income is necessary to meet household needs; so women's market labor behavior is not negatively valued. In addition, Merton and Kitt (1950) suggested that, when individuals are caught between two conflicting reference groups, they will try to come up with a self-appraisal which is a compromise or they will try to seek and adopt a third group for comparison. Thus, because more and more women had experienced market work during the war or the depressions, they themselves began to form a reference group for others. The result is a feedback effect of behavioral change on altering attitudes which is then non-reversible, as clearly shown by the trend of growing approval of women's working status even during a period of demand shortage (i.e., a depression) as from 1972 to 1975 (Duncan \& Duncan, 1978; Vanek, 1980). Today, being a ful1time houseworker has become less rewarding because they are viewed to be more isolated from society, and social identity as a source of self-fulfillment is more likely to be achieved in market jobs (Denney \& Riesman, 1951; Kahn, 1972; Berk \& Berk, 1978; Bose, 1980). We have emphasized in the previous sections that, in order to understand women's labor behavior correctly, we must study the interaction of household members and the nature of a household utility. Combining this with the reference group concept, a woman's market labor will be given a higher value or be encouraged by other members in the household only when her working status improves the household's socio-economic status. More specifically, the reference group theory assumes that each family has a relative socio-economic position to 
its reference group and that the necessary condition for the woman to take a market job is that the socio-economic impact of her working status can improve this relative position or at least not infringe upon it (Sampson \& Ross, 1975). To some extent, this concept is similar to the "relative income hypothesis" first proposed by Hamburger (1955). The relative income hypothesis postulates that a consumer unit's consumption behavior depends not on its absolute income but on its position in the income distribution of the surrounding community. However, the reference group theory is considered to be superior in terms of its broader definition with respect to "reference groups" and the "relative socio-economic status" which treat the "community" and the "relative income position" of the relative income theory as a special case. This deviation will persist as long as income and status are not perfectly interchangeable. The concept of "reference group" has been widely adopted not only in the sociological field but also in the economic discipline, especially in the study of the (spatial) diffusion of wage inflation (e.g., Cripps, 1977; Hanham \& Chang, 1981).

Two problems arise when we want to put into operation the reference group concept in the model: How to identify the reference groups for a household? And how to measure the relative socioeconomic status of a household to its reference groups? It is recognized that, along with the technological advancement in communication and transportation, people are less restricted by spatial segregation in selecting their reference groups (Denney \& Riesman, 1951; Berry, 1973). This is in fact a source of people's changing 
aspirations over time. As a result, there is a trend towards greater and greater consistency in people's reference groups. However, sociologists generally agree that occupation can best represent people's economic status (Youburg, 1974), as has been discussed in the previous sections. The relative socio-economic status of a household to this particular reference group is thus suggested to be measured by the position of the income of the household's head relative to the mean income of his/her referenced occupation group. All that we have suggested here is supported by the empirical evidence that the income of households with working wives is more evenly distributed than that with non-working wives (Sweet, 1971). This means that the involvement of the wife in the labor market makes the family's income closer to the group mean or to the "threshold" as suggested by Oppenheimer (1982). The participation of women in the labor market is a contributory factor in the reduction of the intra-group income variation but has little effect on inter-group income differences (Moore \& Sawhil1, 1976).

Porposition 2.14. The household's relative income status, that is, the husband's income relative to the mean income of the reference group, has a significant effect on the female household members' labor (and thus commuting) behavior. 


\section{MODEL SPECIFICATION}

Based on the shortcomings of past works, the model constructed in this research is characterized by three aspects:

1. Developing out of a rigid utility maximization framework, a simultaneous equation system is specified which takes into consideration the important simultaneous relationship between labor supply and commuting decisions.

2. Some socio-demographic and socio-economic variables found in Chapter II to be influential in female labor supply and commuting behavior are included in the model as control variables.

3. A special estimation technique--the Tobin analysis-is used to correct the selection bias problem (Killingsworth, 1983) and to simulate the non-negative characteristics of the dependent variables (Tobin, 1958)

The findings of the previous chapter suggest that female labor behavior should be studied within a household context rather than on an individual basis. The household or family is the institution in which income is pooled and a consumption decision is jointly made. All the decision-making in each household is geared towards the objective of maximizing its joint utility function. In terms of the "New Home Economics" approach, this means maximizing the output of household production functions--i.e., the commodities. In essence, we can then 
transfer the relationship by suggesting that household utility is a function of the commodities produced and consumed by it. This function is formulated as follows:

$$
\mathrm{U}=\mathrm{f}(\mathrm{Xc}, \mathrm{Lm}, \mathrm{Lw}, \mathrm{H})
$$

Xc: a composite commodity

Lm: leisure consumption of the household head

Lw: leisure consumption of the partner

$\mathrm{H}$ : housing commodity

It is assumed that the household utilities have a Cobb-Douglas functional form. That is:

$$
\mathrm{U}=\mathrm{Xc} \mathrm{Cm}^{\mathrm{b}} \quad \mathrm{Lw} \mathrm{H}^{\mathrm{e}}
$$

The limited income available sets up a budget constraint which means that the consumption or production cost should not exceed full (human and nonhuman) wealth:

$$
\mathrm{Ph} * \mathrm{H}+\mathrm{PC} * \mathrm{Xc}+\mathrm{Cm}+\mathrm{Cw}_{\mathrm{w}}=\mathrm{Ew}^{*} \mathrm{rw}_{\mathrm{w}}+\mathrm{Em}^{*} \mathrm{rm}+\mathrm{V}
$$

where




Also, time as a scarce resource sets up a constraint on utilitymaximizing behavior:

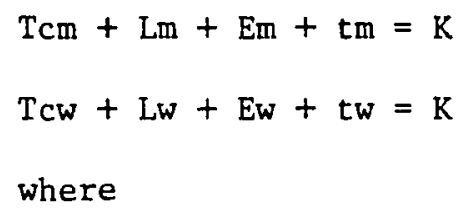

Substitute (5) and (6) into (2):

$\mathrm{Ph}^{*} \mathrm{H}+\mathrm{Pc} * \mathrm{Xc}+\mathrm{Cm}+\mathrm{Cw}=$

$r m(K-L m-t m-T c m)+r w(K-L w-t w-T c w)+V$

By re-arranging it, equation (7) can be re-written as:

$$
\begin{aligned}
& \mathrm{K}(\mathrm{rw}+\mathrm{rm})=\mathrm{Ph}{ }_{\mathrm{H}}+\mathrm{Pc} \star \mathrm{X} \mathrm{c}+\mathrm{Cm}+\mathrm{CW}_{\mathrm{w}} \\
& +\mathrm{rw}^{*} \mathrm{Lw}+\mathrm{rm}^{*} \mathrm{Lm}+\mathrm{rw} \mathrm{w}^{*} \mathrm{tw} \\
& +r m^{*} t m+r w * T c w+r m * T c m
\end{aligned}
$$

This equation can be viewed as a full income constraint on the household. So, it is now, at equilibrium, a problem of maximizing household joint utility function $U$ (equation 1) subject to the full 
income constraint (equation 8). Forming the Lagrangean formulation from equations ( 1 ) and (8) gives the function:

$$
\begin{aligned}
L=U+ & \lambda[K(r w+r m)-P h * H-P c * X c-C m \\
& -C w-r w * L w-r m^{*} L m-r w^{*} t w-r m * t m \\
& \left.-r w^{*} T c w-r m * t c m\right]
\end{aligned}
$$

Take the derivative of $\mathrm{L}$ with respect to each of the utility compoents and equate them to zero to satisfy the first-order condition of optimization:

$$
\begin{aligned}
& \partial \mathrm{L} / \partial \mathrm{Xc}=\mathrm{Ux}-\lambda \mathrm{Pc}=0 \quad \text { i.e. } \mathrm{Ux}=\lambda \mathrm{Pc} \\
& \partial \mathrm{L} / \partial \mathrm{Lm}=\mathrm{UL}_{L}-\lambda \mathrm{rm}=0 \quad \text { i.e. } U L \mathrm{~m}=\lambda \mathrm{rm} \\
& \partial \mathrm{L} / \partial \mathrm{Lw}=\mathrm{ULw}-\lambda \mathrm{rw}=0 \quad \text { i.e. } U L w=\lambda \mathrm{rw} \\
& \partial \mathrm{L} / \partial \mathrm{H}=\mathrm{U}_{H}-\lambda \mathrm{Ph}=0 \quad \text { i.e. } \mathrm{U}_{H}=\lambda \mathrm{Ph} \\
& \partial \mathrm{L} / \partial \lambda=0
\end{aligned}
$$

Equation (14) is in fact the same as equation (7). So $\lambda$ may be interpreted as the marginal utility of income. Equations (11) through (13) thus state that each commodity will be consumed to the point where its marginal utility equals the marginal utility of income times its price.

The theory also provides us with the information that, at equilibrium, the marginal rate of substitution between any two goods is the ratio of one's marginal utility to that of the other and, according to equation (10) - (13), this ratio is related to their relative prices:

$$
\text { M.R.S. }(\mathrm{Lw} \cdot \mathrm{Xc})=-\mathrm{Ux} / \mathrm{U} w=-\mathrm{Pc} / \mathrm{Fw}
$$

According to (1):

$$
\begin{aligned}
& U x=a X c^{a-1} \quad L^{b} \quad L w^{d} H^{e} \\
& \text { ULw d Xc }{ }^{a} \quad L m^{b} \quad L w^{d-1} \quad H e
\end{aligned}
$$


So, $\quad-U x / U=a$ Lw/d XC

Combine equations (15) and (16), and then re-arrange them to get:

$\mathrm{Xc}=\mathrm{a} \mathrm{Lw} \mathrm{rw} / \mathrm{d} \mathrm{Pc}$

From equation (2):

$\mathrm{Xc}=1 / \mathrm{Pc}\left(\mathrm{Ew}_{\mathrm{w}} \mathrm{rw}+\mathrm{Em}_{\mathrm{r}} \mathrm{rm}+\mathrm{V}-\mathrm{Ph} \star_{\mathrm{H}}-\mathrm{Cm}-\mathrm{CW}\right)$

Combine equations (4) and (17):

$$
X c=a L w r w / d P c=a r w / d P c(K-T c w-E w-t w)
$$

Compare equations (18) and (19):

$$
\begin{aligned}
& \text { a } r w / d P c(K-T c w-E w-t w) \\
& =1 / P c(E w * r w+E m * r m+V-P h * H-C m-C w)
\end{aligned}
$$

By rearranging equation (20):

$$
\begin{aligned}
E w= & a / d+a(K-T c w-t w) \\
& -(d / d+a)(E m * r m+V-P h * H-C m-C w) \\
T c w= & (K-E w-t w) \\
& -(d / a r w)(E w * r w+E m * r m+V-P h * H-C m-C w) \\
t w= & (K-T c w-E w) \\
& -(d / a r w)(E w * r w+E m * r m+V-P h * H-C m-C w)
\end{aligned}
$$

The functional forms of equations (21) through (23) are the results of the originally assumed Cobb-Douglas utility function. While this functional form might not behave in the desired fashion because of the restrictions it imposes, equations (21) - (23) do show that the amount of time a woman is willing to devote to market work, her time spent in household services, and time spent in commuting are functions of her (potential or actual) wage rate, the partner's income (if any), 
the household's non-wage income, housing consumption, and the expenditures spent on commuting by the head of the household or the partner; furthermore, they are interdependent on each other. These arguments are supported by Propositions $2.2,2.5,2.7,2.8$. In addition to the variables described in the model, Propositions 2.1 and 2.4 tell us that the time a woman spends on domestic services is a function of the "child effect," which measures the demand for the housework performed by her or the value a household places on it. This is subject to the individual's relative level of home productivity to market productivity as measured by her educational level or schooling completed. Proposition 2.6 suggests that women's labor supply is a function of the availability of the market substitutes for the housework. Since the necessary information on the level of substitution is not available in the data set, it is suggested that it be systematically approximated by the residential location variables: the distance of the place of residence from the nearest Central Business District and the region and size of the nearest city where the household is located (e.g., Thompson, 1965; Berry, 1973; Richardson, 1973). Further, Propositions 2.11 and 2.14 argue that the macro-demand condition (MD) and the household's relative income status (IP) should be added to the labor supply equation. So, from this, we can derive equations:

$$
\begin{aligned}
& E_{W}=\mathrm{G}\left(\mathrm{Tcw} ; \mathrm{tW} ; \mathrm{rW} ; \mathrm{Em} ; \mathrm{rm} ; \mathrm{Ph}^{*} ; \mathrm{V} ; \mathrm{Cm} ; \mathrm{CW} ;\right. \\
& \mathrm{MD} ; \mathrm{IP} ; \mathrm{region} ; \text { city size; d-to-CBD; } \\
& \text { the "Child Effect") } \\
& \mathrm{TCw}=\mathrm{J}(\mathrm{EW} ; \mathrm{tw} ; \mathrm{rw} ; \mathrm{Em} ; \mathrm{rm} ; \mathrm{Ph} \mathrm{H} ; \mathrm{V} ; \mathrm{Cm} ; \mathrm{CW} ; \\
& \text { School; the "Child Effect") }
\end{aligned}
$$




$$
\mathrm{tw}=\mathrm{t}(\mathrm{Ew} ; \mathrm{Tcw} ; \mathrm{rw} ; \mathrm{Em} ; \mathrm{rm} ; \mathrm{Ph} \star \mathrm{H} ; \mathrm{V} ; \mathrm{Cm} ; \mathrm{Cw})
$$

The measurement of income, as the potential wage rate (Propositions 2.9 and 2.10 ), is supposed to be a function of human capital investments including schooling, work experience, on-the-job training, a depreciatory factor--age. That is, $\mathrm{rw}=\mathrm{K}($ Schoo1; Exp; Tran; Age $)$

Thus the model is an equation system composed of four functional relationships. There are some assumptions which are made in the process of building up the model. A full comprehension of these assumptions is necessary because, as a simplifying mechanism, their appearance imposes limitations on the interpretation of the final results--i.e., the results of empirical estimation.

A. It is assumed that what we are able to observe is a small part of a larger system. Thus the current local unemployment rate and market wage rates are assumed to be "exogenously" decided and not to be significantly affected by the changes in the female market labor force supply.

B. The decisions concerning human capital investments, the number and age composition of children, housing consumption, the husband's wage rate and the costs of commuting are made exogenously. That is, at the time the data is collected, these decisions have been made and we are interested in how these reflect female labor behavior. Empirical evidence suggests that, while wives may be secondary workers in the household, their market labor supply is sensitive to changes in their husbands' wages rather than vice versa (Boskin, 1974; Ashenfelter \& Heckman, 1974). So, treating a husband's 
wage rate as exogenous to the model is not unrealistic. On the other hand, as the historical development of female labor behavior has made clear, more and more women now work till the moment the first child is born and/or return to the job market even when their children are under the age of six. Thus even if it is valid to speculate that the female household members, because of the differential expectation of having children, are likely to supply more or less labor to the market than if they are solely judged on their socio-economic and demographic characteristics, the significance of this expectation effect is reduced and will be reflected by such variables as past labor behavior (work experience) and previous decisions made on human capital investment. Both are independent variables in the model constructed in this study.

C. Residential location is assumed to be fixed. This assumption is valid in this study since it is widely agreed in most theoretical and empirical research (e.g., Madden, 1977; Kasper, 1983) that women are more inclined to change employers to avoid longer commuting distances or remain in jobs closer to their homes, in contrast with male workers who are more likely to select or relocate the place of residence depending on employment location.

D. No consideration has been given to the spatial distribution and competition for local labor supply between employers. It is not the intention of this study to model the whole interactive system--the location decision of firms and the residential location decision of workers. 
To sum up, the effectiveness of the model depends on the validity of these assumptions. In the long term, all variables (e.g., fertility, human capital investment, labor decision, etc.) should be endogenous (Berk \& Berk, 1978; Lehrer \& Nerlove, 1980). However, for a crosssectional model dealing with long-run results, it is reasonable to treat some variables characteristic of long-range adjustments as predetermined. What may be implied is that these decisions are made sequentially rather than simultaneously.

\section{ESTIMATION}

For most of the microdata studies on labor supply, two problems with respect to data estimation are likely to raise questions about their interpretation and the conclusions drawn from the derived empirical results.

The first problem stems from the unavoidable fact that some information required to calibrate the model is not available throughout the entire population. For example, market wage data, which is necessary to evaluate the price effect of labor supply, is only available for workers. As a consequence, many investigators only utilize data pertaining to workers to estimate the model. This causes the "selection bias" (Killingsworth, 1983). More explicitly, since labor supply is an endogenous variable, a sample selection based on employment status will systematically skew the distribution of variance. When this happens, the error term of the model is not only relate to the dependent variable--i.e., labor supply--but also related to independent variable(s)--e.g., wage rate. This obviously violates 
the classic assumptions of a regression analysis which maintain, first, that independent variables and the error term in a regression model should be independent of each other; and second, a normal distri-bution of the variance. Heckman (1980) therefore argues that the estimates of the wage elasticity of labor supply derived in those studies using data only relating to workers underestimates the real wage effect on female labor force supply. Figure 3.1 shows how biased estimation occurs. In this study, the adoption of the permanent income theory lends support to the use of the "potential" wage rate as an index of the market return for an individual's possible market labor supply--whether this person currently is a worker or a non-worker. The potential wage rate is estimated using several instrumental variables. These instrument variables are identified through the human capital investment theory.

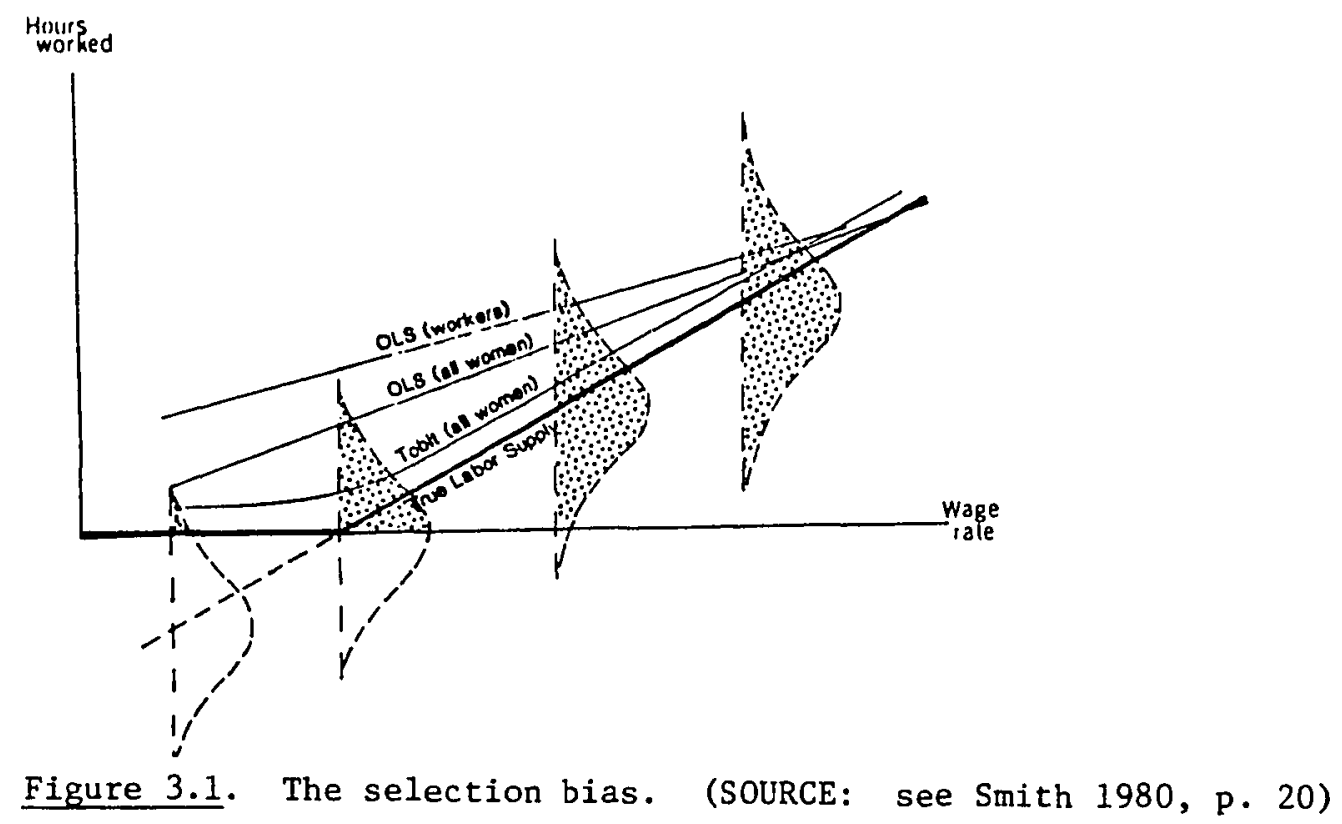


The second problem arises mainly from the fact that the distribution of labor supply is truncated at zero value. So, for those households which put a negative value on their female members' market labor, and thus would demand a negative amount of these women's market labor supply, there is no chance for them to materialize their preference. However, statistical techniques have been devised to deal with this problem by making certain assumptions about the shape of the error distribution in the specified model structure. A most notable one is the Tobit model. By assuming that the population has a normally-distributed error term, the model uses an index to transform the variance distribution from the empirical "truncated" shape to a normal one while the index itself is a function of the independent variables specified in the model. The way that the Tobit estimation approximates the real labor supply phenomenon is also shown in Figure 3.1. The Maximum Likelihood estimation method is employed and all inferential statistics possess asymptotic (large sample size) properties.

As a result, a block recursive model employing a two-stage Tobit and a two stage least square (TSLS) estimation procedure has been adopted in this study. In the first block, a wage equation which specifies the potential or expected wage rate as a function of certain variables showing an individual's predetermined investments in human capital was estimated using the OLS method. Then, the imputed potential wage rate for every female household member was entered into the second block, a simultaneous equation system of labor supply, commuting, and housework. For the labor supply and commuting equations, 
a two-stage Tobit estimation procedure was used. For the housework part, the two-stage least square method was used since all women (except in extremely rare cases) do housework regardless of their status--working or non-working. Table $V$ gives the mean, range, variance, and the number of zero values of housework for white and non-white household groups.

TABLE $V$

WOMEN'S ANNUAL HOUSEWORK HOURS

\begin{tabular}{lcc}
\hline & $\frac{\text { White }}{2}$ & Non-White \\
Number of cases & 677 & 477 \\
Mean & 1530.4 & 1255.2 \\
Standard deviation & 902.2 & 667.5 \\
Number of cases with 0 value & 10 & 18 \\
\hline
\end{tabular}

It follows from the above discussion that the model comprises four equations:

The permanent (potential) wage rate $=k$ (years of schooling completed; age; \# of years worked full time since age 18)

The potential labor supply

$=g$ (the estimated amount of time spent on domestic services and commuting time; the estimated potential wage rate; the partner's wage, labor supply, and distance to work; the household's non-labor income; region; city size; distance-to-CBD; home ownership; 
the local unemployment rate; a household's relative income status)

Time spent on commuting

$=t$ (the estimated amount of time spent on domestic services; the estimated amount of time devoted to a market job; the estimated potential wage rate; the partner's wage, labor supply, and distance to work; the household housing consumption; household's nonlabor income; region; city size; distance to CBD)

Time spent on domestic services

$=\mathrm{h}$ (the estimated amount of time devoted to a market job; the estimated female worker's commuting time; the estimated potential wage rate; the partner's wage, labor supply and distance to work; the household housing consumption; region; city size; distance-to-CBD; \# of children; ages of children; schooling completed; the household's non-labor income)

The functional relationship between some variables has been elaborated by previous theoretical and empirical works. Mincer (1974), from a theoretical viewpoint, proposed a log-linear relationship between wage rate, age, and schooling completed. This functional form was empirically tested and supported by Heckman (1974). Madden (1977) empirically suggested a double-log relationship between labor supply (i.e., hours an individual is willing to work), wage rate, and commuting costs. In this research, the double-log relationship 
between endogenous and exogenous variables involved in the household utility function, and the log-1inear relationship between endogenous variables and the controlled (environment) variables performed much better than if a pure linear formulation had been used. So, $\operatorname{Ln}(\mathrm{rw})=\mathrm{a} 0+\mathrm{al} \operatorname{Sch} I+\mathrm{a} 2 \operatorname{Exp}+\mathrm{a} 3 \mathrm{AGE}+\mathrm{e} 1$ $\operatorname{Ln}(E w)=b 0+b 1 \operatorname{Ln}(r m)+b 2 \operatorname{Ln}(E m)+b 3 \operatorname{Ln}(P h * H)$

$+b 4 \ln (V)+b 5 \ln (r w)+b 6 \ln (t w)$

$+b 7 \ln (\mathrm{TCW})+\mathrm{b} 8 \mathrm{MD}+\mathrm{b} 9 \mathrm{IP}+\mathrm{b} 10 \mathrm{CBD} 2$

$+\mathrm{b} 11 \mathrm{CBD} 3+\mathrm{b} 12 \mathrm{CBD} 4+\mathrm{b} 13 \mathrm{CBD} 5+\mathrm{b} 14 \mathrm{R} 2+\mathrm{b} 15 \mathrm{R} 3$

+ b16 R4 + b17 city + b18 Own + b19 Age6/17 + e2

$\operatorname{Ln}(t w)=c 0+c 1 \operatorname{Ln}(r m)+c 2 \operatorname{Ln}(E m)+c 3 \operatorname{Ln}(P h * H)$

$+c 4 \operatorname{Ln}(\mathrm{V})+c 5 \operatorname{Ln}(\mathrm{rw})+c 6 \operatorname{Ln}(\mathrm{Ew})+c 7 \operatorname{Ln}(\mathrm{Tcw})$

$+\mathrm{c} 8 \mathrm{CBD} 2+\mathrm{c} 9 \mathrm{CBD} 3+\mathrm{c} 10 \mathrm{CBD} 4+\mathrm{c} 11 \mathrm{CBD} 5$

$+c 12 R 2+c 13 R 3+c 14 R 4+c 15$ city $+e 3$

$\operatorname{Ln}(T c w)=d 0+d 1 \operatorname{Sch} 1+d 2 \operatorname{Ln}(r m)+d 3 \operatorname{Ln}(E m)$

$+d 4 \operatorname{Ln}\left(P h \star_{H}\right)+d 5 \operatorname{Ln}(V)+d 6 \operatorname{Ln}(r w)+d 7 \operatorname{Ln}(E w)$

$+\mathrm{d} 8 \mathrm{Ln}(\mathrm{tw})+\mathrm{d} 9$ Age2 $+\mathrm{d} 10$ Age2 $/ 6+311 \mathrm{CBD} 2$

$+\mathrm{d} 12 \mathrm{CBD} 3+\mathrm{d} 13 \mathrm{CBD} 4+\mathrm{d} 14 \mathrm{CBD} 5+\mathrm{d} 15$ City $+\mathrm{e} 4$ 
CHAPTER IV

DATA AND MEASUREMENT

DATA

A Panel Study of Income Dynamics (PSID) provides the most appropriate dataset for the specific needs of this research.

The Study was specially designed to be longitudinal in nature. Surveys have been conducted annually since 1968 and so far, data from fourteen consecutive years has been collected. The area probability (clustered) sampling method was employed to obtain a "representative" cross-section sample. The questionnaires were designed to provide background information on people's behavior as well as insight into the determinants of their economic status. The content of the survey thus covers individual and household demographic characteristics, employment conditions, income, housing and food consumption, mobility, occupation, tax, income transfer, location, and, in addition, attitudinal and expectation variables. Supplementing the interview data is current environmental information including local county unemployment rates, the typical local wage rates for unskilled males and females, etc. Data quality has been well-controlled by a careful editing procedure and a built-in accuracy assessment process. This study uses Survey data from 1979. In accordance with the purpose and basic assumptions of this study, a sub-group of the sample will be selected for analysis, the criteria for selection being: 
1. Non-farmers--Farmers (or agricultural families) are excluded because this population group generally has a different perception and behavior pattern, socially and economically, from other groups. However, since urban farmers are only a small part of the urban labor population (in the dataset only 1.8 percent of all the observations), their exclusion does not affect the significance of this study.

2. The household in equilibrium--The model employed in this study is a (partial) equilibrium model. So any households which have shown signs of not being in an equilibrium condition should obviously not be included if efficient estimation is to be obtained. The aforementioned households are those where a move is planned, those whose members are not satisfied with their current employment status (i.e., the amount of working hours), or those who are thinking about seeking a new job.

3. A household with female member(s)--Since women's behavior is the main interest area of this study, those household which do not have female members should be excluded.

4. A household composed of a couple--Since the household factors are expected to be influential in the determination of female labor behavior, it has been decided to include only those households wherein a head-wife relationship exists in order to capture the effects of the household factors exactly.

5. Non-students--Female household members who have been concentrating their time and efforts on human capital accumulation are not candidates for this study because human capital investment is treated as a predetermined variable in the model. 
All of the variables relating to the criteria used for making the selections just discussed are listed, with the corresponding PSID tape code numbers, in Appendix A. This data reduction procedure creates a quasi-experiment research environment which is supposed to maintain the performance of the model.

\section{MEASUREMENT}

Validity and reliability are the two main criteria with which the measuring mechanisms can be evaluated (Kerlinger, 1964). Validity detects the separation of the measuring surface from the true surface; while reliability is concerned with the stability of the relationship between measured characteristics and the true (conceptual) attributes. The selection of variable measurement is then decided on the basis of these two considerations:

1. Ew; Em (The amount of labor supplied)--Three possible measurements of labor supply are: (i) A discrete choice between "yes" and "no" for the labor decision. That is, an individual either works full-time in the labor market or stays out of it totally. (ii) A continuous variable such as "hours willing to work in the market." By this measurement, part-time work can be evaluated. (iii) A most realistic measurement may be multiple choice measurement. For example, for each individual there may be only three choices--to work fulltime, work half-time (e.g., $20 \mathrm{hrs} /$ week), or stay at home. The time interval of measurement is an important consideration as some jobs are characterized by daily, weekly, or seasonal variation. An annual total may be the best measurement taking all this into account. 
2. Tcw (The time demanded by the household for the woman's domestic services)--A simple time measurement (i.e., annual hours) will be employed in this research. Using the unit of time here provides a challenge since housework is argued to be mostly taskoriented in contrast to the time-oriented nature of market work (Berk \& Berk, 1978; Nelson, 1980; Strasser, 1980). The task-oriented characteristics means that "sequence" is important, that activities frequently overlap, and that the value of the time unit is not homogeneous during the day or during the days within a week.

3. tw (The time spent in commuting)--A simple time unit measurement will be employed. Although commuting time is a function of the distance from home to work, the exact functional relationship is not clear and is subject to the characteristics of the local transportation system.

4. $\mathrm{Cm} ; \mathrm{Cw}$ (The costs of commuting)--The costs of transportation may include operating costs of the automobile used (if any), the gasoline expenditure, parking, licenses; and, if public transportation is used, the expenditure on tickets or passes. Since direct measurement of these expenditures is not available in the dataset and the usually used proxy variable--distance--is highly correlated to the commuting time (e.g., a simple correlation coefficient of 0.72 and 0.68 , for white and non-white groups respectively, in this dataset), some location variables (i.e., region, distance to CBD, city size) are introduced to capture the systematic variation in commuting expenditure. The mode of travel, which normally accounts for most of the variation 
in traveling expenditure cannot be included since this information is available only for workers.

5. rw;rm (Permanent or potential wage rates)--These variables are measured at the annual average hourly earning. However, it is frequently argued that the measured potential earning capacity is an underestimation of the real earning since the human capital gain from working--experience--is not included in the measurement (Pynn, 1969; Kreps \& Leaper, 1976). Mincer (1974) empirically tested this postulate and concluded that the observed wage rate (per hour) was about 80 percent of the marginal price of labor supply for workers below college level and 60 percent for workers with a higher level of education. No adjustment is intended here to take this into consideration as there has still not been sufficient empirical work done on it to provide a convincing estimate.

6. $\mathrm{Ph} \star_{\mathrm{H}}$ (Housing consumption)--This variable is the total expenditure spent on housing, which may include maintenance costs, rent, taxes, etc. No effort is required, with respect to the purpose of this study, to separate the price of housing and the amount of housing consumed.

A direct monetary measurement of housing consumption is available in the dataset: the annual rent for those renters, the annual mortgage payment plus property tax for those homeowners, and the equivalent annual rent for those living in a house free of charge. This measurement ignores the consumption payment generated from mortgage down payment, and thus underestimates the amount of housing consumption of those homeowners. However, it is hoped that the saving from the 
income tax deductible interest on home mortgage loans will help dilute this measurment problem, and that the inclusion of a homeownership dummy variable in the model may help correct, at least partly, the bias.

7. V (Non-labor income)--In this study, this wealth component is measured by adding up the property income, interest, and stock gains. The assumption is that other sources of income are either insignificant or are transitory in nature and exert insignificant influence on household behavior. A hetroskasdacity problem may be caused because larger households might well have more grown-up working children who contribute to a significant part of the household income and this source of income may be treated as an asset income by the parents (e.g., Ashenfelter \& Heckman, 1974).

8. Age2, Age2-5, Age 6-17 (The child effect)--The child effect is expressed through three variables. The first and the second variables are the number of children under the age of two and between the ages of two and six in the household; the third variable is the number of children in the age range $6-17$. The number of the children above age eighteen is not included since its effect is indeterminate: On the one hand they need more parental (monetary) support to obtain a college education but on the other hand they tend to leave home and live independently (i.e., form their own household), or they might work and therefore contribute to the household income.

9. Human capital investments--Three variables are involved: schooling completed, experience, and on-the-job training. All are measured in years. It is widely argued that schooling cannot correctly 
indicate an individual's earning ability, but the hypothesis that more male persons will, generally, through a self-selecting process, desire more education--schooling--supports the measurement here.

10. $\mathrm{CBD} 2, \mathrm{CBD} 3, \mathrm{CBD} 4, \mathrm{CBD} 5$ (Dummy variables for the distance to $\mathrm{CBD}$ )--Since the level of market substitution for housework is not readily available in the data, the distance-to CBD has been adopted as a proxy variable for this effect. The main rationale of this selection is derived from the postulate of some urban ecologists that most market services are less available (or more expensive to purchase) the farther a household is located from the CBD (e.g., Berry, 1973). In other words, households located in outlying areas are more "isolated."

11. Own (Home ownership)--Home ownership is included in the model to detect the "tax effect." Some labor economists argue that, while most women workers are secondary earners in the household, they suffer from higher average tax rates because their income is taxed at the household's (pooled) marginal income tax rates. While home ownership has been widely recognized as being the most popular tax shelter, the inclusion of this variable gives us a chance to test the significance of the tax effect aforementioned.

12. Race--Ethnic background, as a criterion for market segmentation is grouped based upon two considerations. First, the grouping must be done in a way to warrant the largest between-group difference. Second, there must be a sufficient number of observations in each group to support the asymptotic property of statistical testing the twostage methods possess. Accordingly, ethnic background is aggregated into two groups--white and non-white. Blacks, Spanish-Americans, and other racial groups such as Asians, Indians, etc. are placed in one 
category--non-white. This may cause a larger variation in the data and reduce the performance (i.e., goodness-of-fit) of the model.

13. Occupation--The categorization of occupations has always been rather arbitrary and subject to the context of the research. In this study, occupation is used to define the households of different socio-economic status. This is mainly done by categorizing the occupations of the household heads into four groups:

1. Service workers, unskilled laborers;

2. Operative and kindred workers, craftsmen;

3. Sales workers, clerical and kindred workers;

4. Professional and technical workers; managers.

The environmental information needed in this study is:

14. The local labor market conditions--This is put into operation by the local unemployment rates at the time the survey was conducted.

15. Regional difference--It is widely recognized that there are regional differentials in wage rates. Also, some institutional factors exert differential effects on different regions--e.g., income maintenance programs have much more influence in the South.

16. City (Size of the largest city in the area)--Regional scientists or urban economists have long been waiting to see a systematic relationship between the size of the city and wage rate (e.g., Richardson, 1973). That is, as a result of fiercer competition for limited resources (i.e., land, capital, etc.), a market equilibrium process forces all prices (including the wage rate) to be higher 
in large cities than in smaller ones. This variable is thus included to help capture the "location of residence" effect.

17. DEV (The reference group effect)--Since the reference group theory postulates that a household tends to imitate the consumption pattern of its peer group(s), the effect is thus measured in this study by the deviation of a husband's income from the mean income of the occupational group he belongs to. The basic assumption which validates the use of this measurement is that other non-monetary component (s) of the reference group effect is trivial or insignificant in the determination of the wife's labor behavior.

All of the variables relating to the factors described above, with the corresponding PSID tape codes and the measurenent scale, are listed in Appendix B. 


\section{CHAPTER V}

EMPIRICAL RESULTS

Parameter estimates of women's potential market wage rate and the equation system of household demand for women's labor supply, commuting time, and housework covering white and non-white groups are given in Table VI (white) and Table VII (non-white). The associated (asymptotic) $t$ values are given in the parentheses below the estimates. The $R$ value for each equation, which is calculated as one minus the ratio of the residual sum of squares to the total variation of the dependent variable, is given at the end of each column. This value, generally named the determinant of the goodness-of-fit, serves as a basic indicator of the performance of the model. In the last row of the table are the test statistics for each equation. For wage, labor supply, and commuting equations which use Tobit estimation, the statistics are the values of the $\log$-likelihood ratio defined as:

Log-Likelihood Ratio $=-2$ Ln \# where $\#=L(a 0, a 1, \ldots . ., a k, a) / L^{*}(a 0,0, \ldots ., 0 a)$

$L \& L^{*}$ are the maximum value (with respect to a's of the likelihood of a sample

$k$ is the number of independent variables in the equation

a is the inverse of the standard deviation of the error term. 
Under the null hypothesis that $a 1=a 2=\ldots .=a k=0$. This statistic is asymptotically approximated by Chi-square distribution with $\mathrm{k}$ degree of freedom. For the housework equation estimated by the ordinary least square (OLS) method, the value is an F statistic defined as:

$F(k, n-k-1)=M S e / M S u$ where MSe is the mean squared error which can be explained by the equation

MSu is the mean squared error which cannot be explained by the equation

$\mathrm{k}$ is the number of independent variables

$\mathrm{n}$ is the number of sample observations

The critical values of these statistics, at the significance level of 0.01 , are given in the parentheses below them. From the tests it is evident that the null hypothesis should be rejected fur all the equations in the white group.

Generally speaking, the values of $R^{2}$ 's are compatible with other similar empirical works.* The model fits equally well for the white and the non-white household groups. The significance patterns estimated for the two groups are very similar. This result is quite surprising as the non-white household group, which includes Oriental, Hispanic, and Black households, is considered to be much less homogeneous than the white household with respect to the preference pattern; and a model trying to systematically fit a general preference

*For example, see Hanoch (1980), Cain (1966) for the wate equation; see Hanoch (1980) and Schultz (1980) for the labor supply model. 
TABLE VI

THE REGRESSION ESTIMATES (WHITE HOUSEHOLDS)

\begin{tabular}{|c|c|c|c|c|}
\hline & $\begin{array}{l}\text { Potential } \\
\text { Wage Rate }\end{array}$ & $\begin{array}{l}\text { Labor } \\
\text { Supply }\end{array}$ & $\begin{array}{l}\text { Conmuting } \\
\text { Time }\end{array}$ & $\begin{array}{c}\text { Housework } \\
\text { Time }\end{array}$ \\
\hline \multicolumn{5}{|l|}{$\begin{array}{l}\text { Human Capital } \\
\text { Investment: }\end{array}$} \\
\hline Age & $\begin{array}{l}-0.059 * * \\
(-5.80)\end{array}$ & & & \\
\hline Education & $\begin{array}{l}0.193 * * \\
(4.12)\end{array}$ & & & $\begin{array}{l}-0.075 * \\
(-3.09)\end{array}$ \\
\hline $\begin{array}{l}\text { Yrs. worked } \\
\text { since } 18\end{array}$ & $\begin{array}{l}0.129 * * \\
(8.14)\end{array}$ & & & \\
\hline \multicolumn{5}{|l|}{ Household Factors: } \\
\hline $\begin{array}{l}\text { Husband's wage } \\
\text { rate }\end{array}$ & & $\begin{array}{l}3.670 * \star \\
(4.69)\end{array}$ & $\begin{array}{l}0.322 \\
(0.74)\end{array}$ & $\begin{array}{l}0.295 * * \\
(4.72)\end{array}$ \\
\hline $\begin{array}{l}\text { Husband's labor } \\
\text { supply }\end{array}$ & & $\begin{array}{l}4.374 * * \\
(4.79)\end{array}$ & $\begin{array}{l}0.636 \\
(1.14)\end{array}$ & $\begin{array}{l}0.317 * \star \\
(5.82)\end{array}$ \\
\hline $\begin{array}{l}\text { HH nonlabor } \\
\text { income }\end{array}$ & & $\left(\begin{array}{l}0.117 * \\
2.25)\end{array}\right.$ & $\begin{array}{l}-0.058 \\
(-1.17)\end{array}$ & $\left(\begin{array}{l}0.035 * * \\
(2.56)\end{array}\right.$ \\
\hline $\begin{array}{l}\text { HH housing } \\
\text { consump. }\end{array}$ & & $\begin{array}{l}0.665 \\
(1.80)\end{array}$ & $\begin{array}{l}0.135 \\
(0.41)\end{array}$ & $\begin{array}{l}-0.166^{\star} \\
(-1.96)\end{array}$ \\
\hline $\begin{array}{l}\text { HH home owner- } \\
\text { ship (dumny) }\end{array}$ & & $\begin{array}{l}1.120 \\
(1.68)\end{array}$ & & \\
\hline $\begin{array}{l}\text { Husband's d-to- } \\
\text { work }\end{array}$ & & $\begin{array}{l}-1.191 * * \\
(-4.36)\end{array}$ & $\begin{array}{l}-0.115 \\
(-0.59)\end{array}$ & $\begin{array}{l}-0.077 \star \\
(-2.02)\end{array}$ \\
\hline \multicolumn{5}{|l|}{ Child Effect: } \\
\hline $\begin{array}{l}\# \text { of children } \\
<2\end{array}$ & & & & $\begin{array}{l}0.283 \\
(1.87)\end{array}$ \\
\hline $\begin{array}{l}\text { \# of children } \\
3-6\end{array}$ & & & & $\begin{array}{l}0.055 \\
(0.58)\end{array}$ \\
\hline $\begin{array}{l}\# \text { of children } \\
7-18\end{array}$ & & $\left(\begin{array}{l}0.971 * \star \\
3.91)^{*}\end{array}\right.$ & & \\
\hline
\end{tabular}


TABLE VI-- Continued

\begin{tabular}{|c|c|c|c|c|}
\hline & $\begin{array}{l}\text { Potential } \\
\text { Wage Rate }\end{array}$ & $\begin{array}{l}\text { Labor } \\
\text { Supply }\end{array}$ & $\begin{array}{c}\text { Commuting } \\
\text { Time }\end{array}$ & $\begin{array}{l}\text { Housework } \\
\text { I'ime }\end{array}$ \\
\hline \multicolumn{5}{|l|}{$\begin{array}{l}\text { Local Economic } \\
\text { Condition: }\end{array}$} \\
\hline $\begin{array}{l}\text { Unemployment } \\
\text { rate }\end{array}$ & & $\begin{array}{l}0.187 \\
(1.74)\end{array}$ & & \\
\hline \multicolumn{5}{|l|}{$\begin{array}{c}\text { Reference Group } \\
\text { Effect: }\end{array}$} \\
\hline $\begin{array}{l}\text { Deviation from } \\
\text { group mean }\end{array}$ & & $\begin{array}{l}-0.189 * t \\
(-4.40)\end{array}$ & & \\
\hline \multicolumn{5}{|l|}{ Place of Residence: } \\
\hline $\begin{array}{l}\text { North Central } \\
\text { (dummy) }\end{array}$ & $\begin{array}{l}0.056 \\
(0.20)\end{array}$ & $\begin{array}{l}-1.090 \\
(-1.72)\end{array}$ & $\begin{array}{r}-0.697 \\
(-1.47)\end{array}$ & $\begin{array}{l}0.083 \\
(0.62)\end{array}$ \\
\hline South (dummy) & $\begin{array}{l}0.179 \\
\left(\begin{array}{l}0.63)\end{array}\right)\end{array}$ & $\begin{array}{l}-1.030 \\
(-1.64)\end{array}$ & $\begin{array}{r}-0.621 \\
(-1.29)\end{array}$ & $\begin{array}{l}0.057 \\
(0.43)\end{array}$ \\
\hline West (dummy) & $\begin{array}{l}-0.486 \\
(-1.52)\end{array}$ & $\begin{array}{l}-2.797 * \star \\
(-3.37)\end{array}$ & $\begin{array}{l}-0.641 \\
(-1.01)\end{array}$ & $\begin{array}{l}-0.161 \\
(-1.20)\end{array}$ \\
\hline CBD2 (dummy) & & $\begin{array}{l}0.146 \\
(0.35)\end{array}$ & $\begin{array}{l}0.309 \\
(0.79)\end{array}$ & $\begin{array}{l}0.049 \\
(0.50)\end{array}$ \\
\hline CBD3 (dummy) & & $\begin{array}{l}0.476 \\
(0.65)\end{array}$ & $\begin{array}{l}0.412 \\
(0.59)\end{array}$ & $\begin{array}{l}-0.122 \\
(-0.70)\end{array}$ \\
\hline CBD4 (dummy) & & $\begin{array}{l}-0.260 \\
(-0.17)\end{array}$ & $\begin{array}{l}1.022 \\
0.74)\end{array}$ & $\begin{array}{l}0.067 \\
(0.18)\end{array}$ \\
\hline CBD5 (dummy) & & $\begin{array}{l}-2.990 \\
(-1.39)\end{array}$ & $\begin{array}{l}-0.912 \\
(-0.48)\end{array}$ & $\begin{array}{l}0.322 \\
(0.72)\end{array}$ \\
\hline City size & $\begin{array}{l}-0.080 \\
(-1.02)\end{array}$ & $\begin{array}{l}-0.059 \\
(-0.42)\end{array}$ & $\begin{array}{l}-0.086 \\
(-0.64)\end{array}$ & $\begin{array}{l}0.060 \\
(1.80)\end{array}$ \\
\hline
\end{tabular}

Endogenous

Variables:

Wife's Wage

Rate

$\begin{array}{lll}1.022 * * & -0.305 & -0.006 \\ (3.06) & (-0.98) & (-0.05)\end{array}$


TABLE VI--Continued

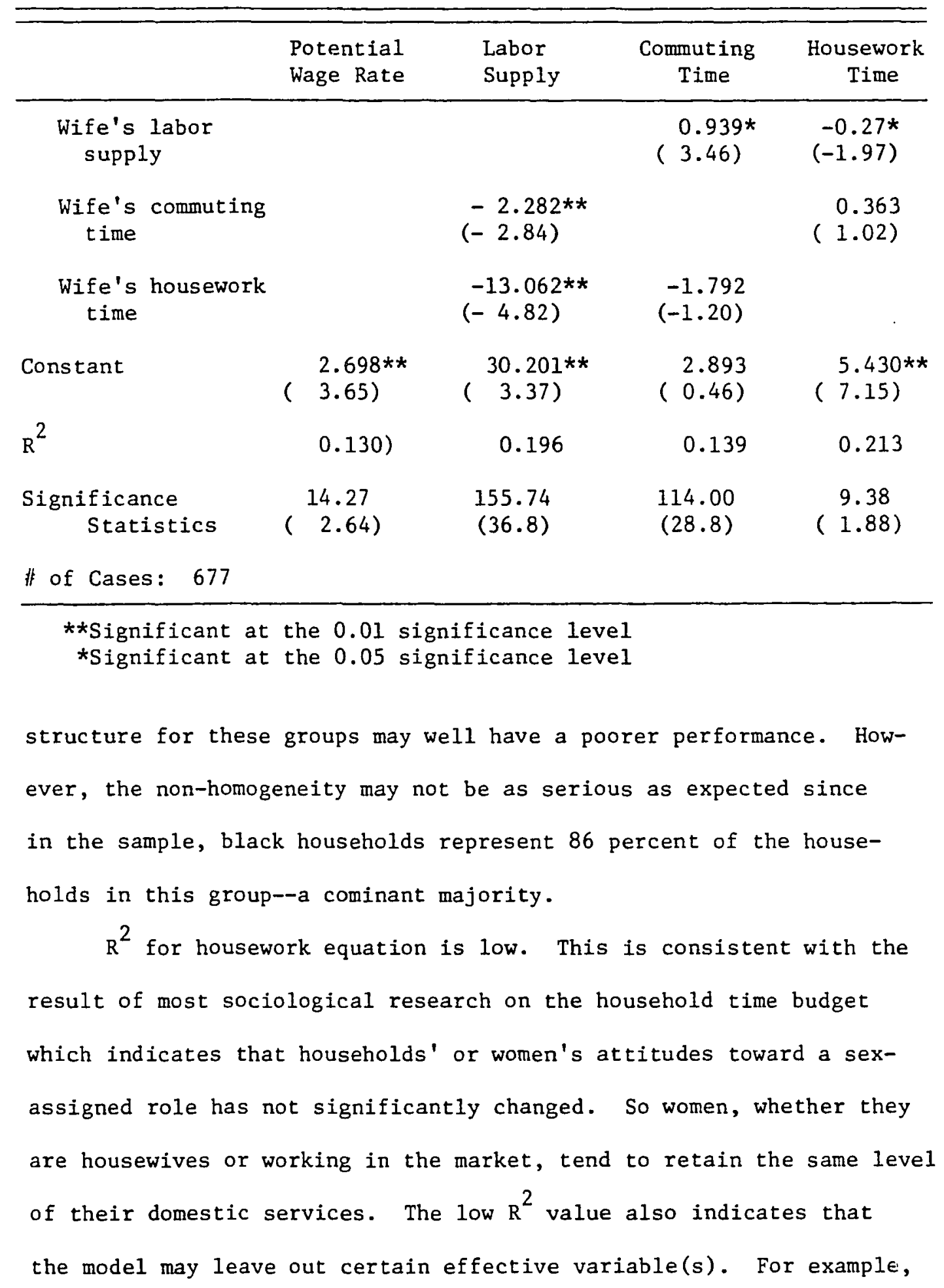


TABLE VII

THE REGRESSION ESTIMATES (NON-WHITE HOUSEHOLD)

\begin{tabular}{|c|c|c|c|c|}
\hline & $\begin{array}{l}\text { Potential } \\
\text { Wage Rate }\end{array}$ & $\begin{array}{l}\text { Labor } \\
\text { Supply }\end{array}$ & $\begin{array}{l}\text { Commuting } \\
\text { Time }\end{array}$ & $\begin{array}{c}\text { Housework } \\
\text { Time }\end{array}$ \\
\hline \multicolumn{5}{|l|}{$\begin{array}{l}\text { Human Capital } \\
\text { Investment: }\end{array}$} \\
\hline Age & $\begin{array}{l}-0.087 \star \star \\
(-6.41)\end{array}$ & & & \\
\hline Education & $\left(\begin{array}{l}0.229 * * \\
(4.71)\end{array}\right.$ & & & $\begin{array}{l}-0.050 \\
(-1.29)\end{array}$ \\
\hline $\begin{array}{l}\text { Yrs. worked } \\
\text { since } 18\end{array}$ & $\begin{array}{l}0.109 * * \\
5.98)\end{array}$ & & & \\
\hline \multicolumn{5}{|l|}{ Household Factors: } \\
\hline $\begin{array}{l}\text { Husband's wage } \\
\text { rate }\end{array}$ & & $\begin{array}{l}2.932 \star \\
(2.20)\end{array}$ & $\begin{array}{l}-0.675 \\
(-2.14)\end{array}$ & $\begin{array}{l}0.093 \\
(0.76)\end{array}$ \\
\hline $\begin{array}{l}\text { Husband's labor } \\
\text { supply }\end{array}$ & & $\begin{array}{l}4.642 \star \star \\
(3.06)\end{array}$ & $\begin{array}{l}0.433 \\
(1.42)\end{array}$ & $\begin{array}{l}0.313 * * \\
(3.35)\end{array}$ \\
\hline $\begin{array}{l}\text { HH nonlabor } \\
\text { income }\end{array}$ & & $\left(\begin{array}{l}0.716^{*} \\
2.06)\end{array}\right.$ & $\begin{array}{l}0.048 \\
(0.53)\end{array}$ & $\begin{array}{l}-0.127 * \\
(-2.20)\end{array}$ \\
\hline $\begin{array}{l}\text { HH housing } \\
\text { consump. }\end{array}$ & & $\begin{array}{l}0.316 \\
(\quad 0.97)\end{array}$ & $\begin{array}{l}0.234 \\
(0.79)\end{array}$ & $\begin{array}{l}-0.011 \\
(-0.11)\end{array}$ \\
\hline $\begin{array}{l}\text { HH home owner- } \\
\text { ship (dummy) }\end{array}$ & & $\begin{array}{l}-10.590 * * \\
(-2.60)\end{array}$ & & \\
\hline $\begin{array}{l}\text { Husband's d-to } \\
\text { work }\end{array}$ & & $\begin{array}{l}-0.829 * * \\
(-2.63)\end{array}$ & $\begin{array}{l}-0.141 \\
(-0.75)\end{array}$ & $\begin{array}{l}-0.086 \\
(-1.28)\end{array}$ \\
\hline \multicolumn{5}{|l|}{ Child Effect: } \\
\hline $\begin{array}{l}\text { \# }{ }_{2} \text { children } \\
\end{array}$ & & & & $\begin{array}{l}-0.177 \\
(-1.04)\end{array}$ \\
\hline $\begin{array}{l}\text { \# of children } \\
3-6\end{array}$ & & & & $\begin{array}{l}-0.161 \\
(-1.01)\end{array}$ \\
\hline $\begin{array}{l}\text { \# of children } \\
7-18\end{array}$ & & $\begin{array}{l}1.033^{* *} \\
2.57)^{2}\end{array}$ & & \\
\hline
\end{tabular}


TABLE VII--Continued

\begin{tabular}{|c|c|c|c|c|}
\hline & $\begin{array}{l}\text { Potential } \\
\text { Wage Rate }\end{array}$ & $\begin{array}{l}\text { Labor } \\
\text { Supply }\end{array}$ & $\begin{array}{l}\text { Commuting } \\
\text { Time }\end{array}$ & $\begin{array}{l}\text { Housework } \\
\text { Time }\end{array}$ \\
\hline \multicolumn{5}{|l|}{$\begin{array}{l}\text { Local Economic } \\
\text { Condition: }\end{array}$} \\
\hline $\begin{array}{l}\text { Unemployment } \\
\text { rate }\end{array}$ & & $\begin{array}{l}-0.010 \\
(-0.08)\end{array}$ & & \\
\hline \multicolumn{5}{|l|}{$\begin{array}{c}\text { Reference Group } \\
\text { Effect: }\end{array}$} \\
\hline $\begin{array}{c}\text { Deviation from } \\
\text { group mean }\end{array}$ & & $\begin{array}{l}-0.237 * * \\
(-3.10)\end{array}$ & & \\
\hline \multicolumn{5}{|l|}{ Place of Residence: } \\
\hline $\begin{array}{l}\text { North Central } \\
\text { (dummy) }\end{array}$ & $\begin{array}{l}-0.560 \\
(-1.10)\end{array}$ & $\begin{array}{l}-8.210 * \\
(-2.54)\end{array}$ & $\begin{array}{l}0.545 \\
\left(\begin{array}{l}0.56)\end{array}\right)\end{array}$ & $\begin{array}{l}-0.602 \\
(-1.92)\end{array}$ \\
\hline South (dummy) & $\begin{array}{l}0.330 \\
(0.76)\end{array}$ & $\begin{array}{l}-4.726 \star \\
(-2.39)\end{array}$ & $\begin{array}{l}0.094 \\
(\quad 0.12)\end{array}$ & $\begin{array}{l}-0.289 \\
(-1.10)\end{array}$ \\
\hline West (dummy) & $\begin{array}{l}1.016^{*} \\
1.97)\end{array}$ & $\begin{array}{l}-7.621^{*} \\
(-2.53)\end{array}$ & $\begin{array}{l}-0.771 \\
(-0.82)\end{array}$ & $\begin{array}{l}-0.083 \\
(-0.20)\end{array}$ \\
\hline CBD2 (dummy) & & $\begin{array}{l}-0.079 \\
(-0.18)\end{array}$ & $\begin{array}{l}0.204 \\
(0.51)\end{array}$ & $\begin{array}{l}0.359 * \\
(2.50)\end{array}$ \\
\hline CBD3 (dummy) & & $\begin{array}{l}-1.041 \\
(-1.36)\end{array}$ & $\begin{array}{l}-0.017 \\
(-0.02)\end{array}$ & $\begin{array}{l}-0.260 \\
(-1.05)\end{array}$ \\
\hline CBD4 (dummy) & & $\begin{array}{l}-0.690 \\
(-0.38)\end{array}$ & $\begin{array}{l}-2.546 \\
(-1.39)\end{array}$ & $\begin{array}{l}0.337 \\
(0.56)\end{array}$ \\
\hline CBD5 (dummy) & & $\begin{array}{l}-7.050 * \star \\
(-2.97)\end{array}$ & $\begin{array}{l}-21.626 \\
-0.01)\end{array}$ & $\begin{array}{l}-1.936 * t \\
(-3.16)\end{array}$ \\
\hline City size & $\begin{array}{l}-0.217 \\
(-1.89)\end{array}$ & $\begin{array}{l}-0.188 \\
(-0.90)\end{array}$ & $\begin{array}{l}-0.092 \\
(-0.48)\end{array}$ & $\begin{array}{l}0.099 \\
(1.41)\end{array}$ \\
\hline
\end{tabular}

Endogenous

Variables:

Wife's wage

$2.705 * * \quad 0.718 * \quad 0.675 * *$

rate

$\left(\begin{array}{l}2.47) \quad(1.99) \\ \text { (1) }\end{array}\right.$

( 3.97$)$ 
TABLE VII--Continued

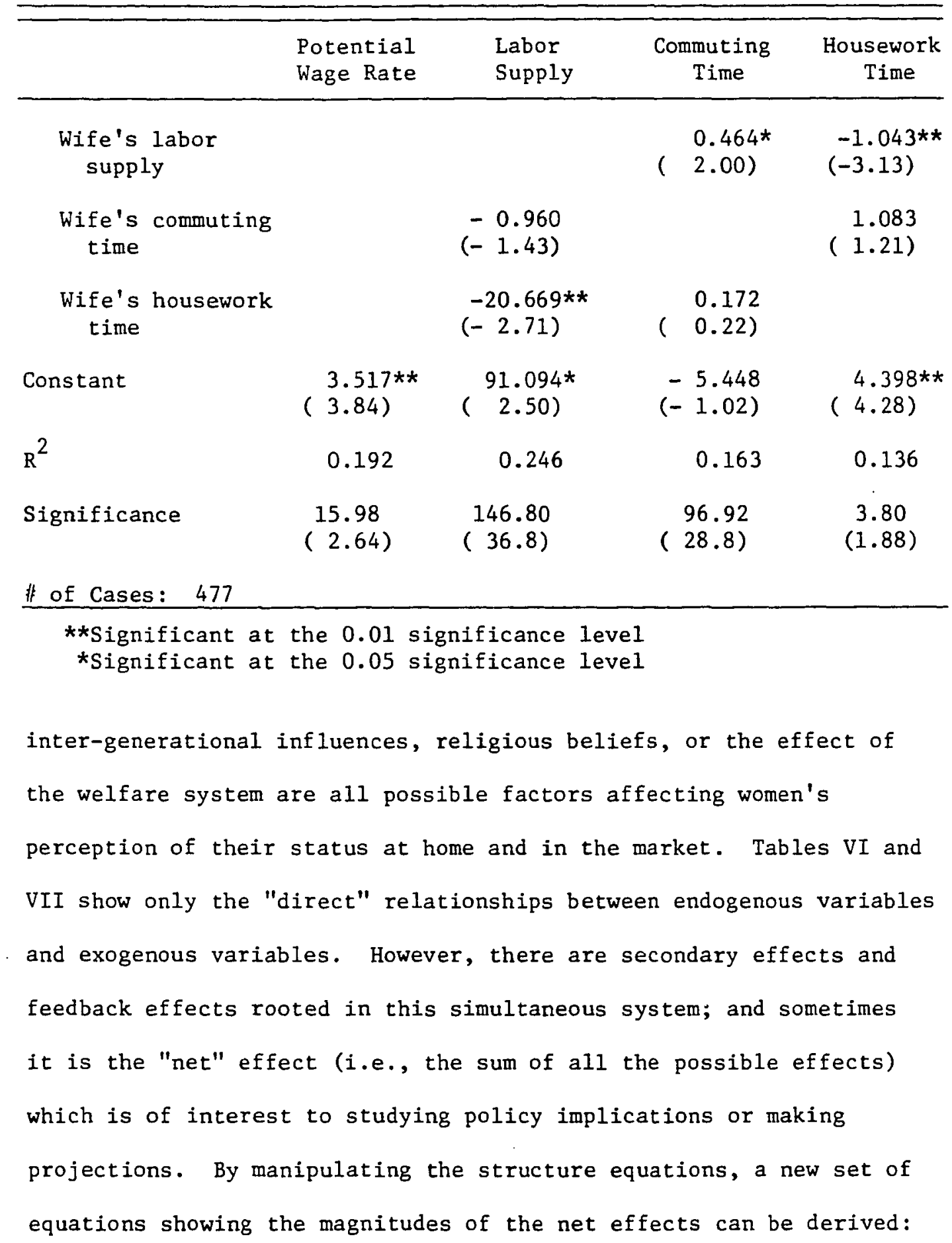


Original structure equations:

$\mathrm{EW}_{\mathrm{w}}=\mathrm{Al}+\mathrm{bl} \mathrm{tw}+\mathrm{cl} \mathrm{TcW}$

$\mathrm{tw}=\mathrm{A} 2+\mathrm{b} 2 \mathrm{Ew}+\mathrm{c} 2 \mathrm{Tcw}$

$\mathrm{Tcw}=\mathrm{A} 3=\mathrm{b} 3 \mathrm{Ew}+\mathrm{c} 3 \mathrm{tw}$

where Ew, tw, and Tcw represent labor supply, community time, and housework time respectively, and A1, A2, and A3 represent the vectors for all other exogenous variables (including regression coefficients) in each equation, By re-arranging the above equations:

$E w-b 1$ tw $-c 1$ Tcw $=A l$

$-b 2 E w+t w-c 2 T c w=A 2$

$-b 3 E w-c 3 t w+T c w=A 3$

Presented in matrix form:

$\left[\begin{array}{ccc}1 & -b 1 & -c 1 \\ -b 2 & 1 & -c 2 \\ -b 3 & -c 3 & 1\end{array}\right]\left[\begin{array}{l}E w \\ t w \\ T c w\end{array}\right]=\left[\begin{array}{l}A 1 \\ A 2 \\ A 3\end{array}\right]$

Solving the above relationship for the endogenous variables:

$$
\left[\begin{array}{l}
E w \\
t w \\
T c w
\end{array}\right]=\left[\begin{array}{ccc}
1 & -b 1 & -c 1 \\
-b 2 & 1 & -c 2 \\
-b 3 & -c 3 & 1
\end{array}\right]^{-1}\left[\begin{array}{l}
A 1 \\
A 2 \\
A 3
\end{array}\right]
$$

The resulting reduced-form equations, which show the net effects of exogenous variables on the endogenous variables, for white and non-white households respectively, are given in Table VIII and Table IX. 
TABLE VIII

THE REDUCED-FORM EQUATIONS (WHITE HOUSEHOIDS)

\begin{tabular}{|c|c|c|c|c|}
\hline & \multicolumn{4}{|c|}{ Wife's } \\
\hline & $\begin{array}{l}\text { Potential } \\
\text { Wage Rate }\end{array}$ & $\begin{array}{l}\text { Labor } \\
\text { Supply }\end{array}$ & $\begin{array}{l}\text { Commuting } \\
\text { Time }\end{array}$ & $\begin{array}{c}\text { Housework } \\
\text { Time }\end{array}$ \\
\hline \multicolumn{5}{|l|}{ Human Capital Investment: } \\
\hline Age & $-0.059 *$ & & & \\
\hline Education & $0.193^{*}$ & $0.116 *$ & $0.182 \star$ & $-0.041 *$ \\
\hline Yrs. worked since 18 & $0.129 *$ & & & \\
\hline \multicolumn{5}{|l|}{ Household Factors: } \\
\hline Husband's wage rate & & $0.200 *$ & $0.048 *$ & $0.256 *$ \\
\hline Husband's 1abor supply & & $-0.015 *$ & $0.028 *$ & $0.329 *$ \\
\hline HH nonlabor income & & $0.050 *$ & $-0.030 *$ & $0.010 *$ \\
\hline $\mathrm{HH}$ housing consump. & & $0.284 *$ & $0.508 *$ & $-0.060 *$ \\
\hline $\begin{array}{l}\text { HH home ownership } \\
\text { (dummy) }\end{array}$ & & 0.320 & 0.278 & 0.012 \\
\hline Husband's d-to-work & & $-0.081 *$ & $-0.056 *$ & $-0.075 *$ \\
\hline \multicolumn{5}{|l|}{ Child Effect: } \\
\hline \# of children $<2$ & & -0.439 & -0.688 & 0.154 \\
\hline \# of children $3-6$ & & -0.085 & -0.134 & 0.030 \\
\hline \# of children 7-18 & & $0.278 *$ & $0.241^{*}$ & $0.011 *$ \\
\hline \multicolumn{5}{|l|}{ Local Economic Condition: } \\
\hline Unemployment rate & & 0.053 & 0.046 & 0.002 \\
\hline Reference Group Effect: & & & & \\
\hline $\begin{array}{c}\text { Deviation from } \\
\text { group mean }\end{array}$ & & $-0.054 *$ & $-0.047 *$ & $-0.002 *$ \\
\hline
\end{tabular}


TABLE VIII--Continued

\begin{tabular}{|c|c|c|c|c|}
\hline & \multicolumn{4}{|c|}{ Wife's } \\
\hline & $\begin{array}{l}\text { Potential } \\
\text { Wage Rate }\end{array}$ & $\begin{array}{l}\text { Labor } \\
\text { Supply }\end{array}$ & $\begin{array}{c}\text { Commuting } \\
\text { Time }\end{array}$ & $\begin{array}{c}\text { Housework } \\
\text { Time }\end{array}$ \\
\hline \multicolumn{5}{|l|}{ Place of Residence: } \\
\hline North Central (dummy) & & 0.407 & -0.159 & -0.086 \\
\hline South (dummy) & 0.056 & 0.372 & -0.115 & -0.086 \\
\hline West (dummy) & 0.179 & $0.229 *$ & $-0.014^{*}$ & $-0.228 *$ \\
\hline CBD2 (dummy) & -0.486 & -0.410 & -0.222 & 0.081 \\
\hline CBD3 (dummy) & & -0.175 & 0.230 & 0.009 \\
\hline CBD4 (dummy) & & -1.421 & -0.686 & 0.208 \\
\hline CBD5 (dummy) & & -0.246 & -1.115 & -0.014 \\
\hline City size & -0.080 & -0.005 & -0.122 & 0.017 \\
\hline Wife's Wage Rate & & $0.672 *$ & $0.405 *$ & $-0.044 *$ \\
\hline \multicolumn{5}{|l|}{ Wife's Labor Supply } \\
\hline \multicolumn{5}{|l|}{ Wife's Commuting Time } \\
\hline \multicolumn{5}{|l|}{ Wife's Housework Time } \\
\hline Constant & 2.698 & $-3.313^{*}$ & $-7.020 *$ & $3.781 *$ \\
\hline
\end{tabular}

*Significant at the 0.05 significance level 
TABLE IX

THE REDUCED-FORM EQUATIONS (NON-WHITE HOUSEHOLDS)

\begin{tabular}{|c|c|c|c|c|}
\hline & \multicolumn{4}{|c|}{ Wife's } \\
\hline & $\begin{array}{l}\text { Potential } \\
\text { Wage Rate }\end{array}$ & $\begin{array}{l}\text { Labor } \\
\text { Supply }\end{array}$ & $\begin{array}{c}\text { Commuting } \\
\text { Time }\end{array}$ & $\begin{array}{l}\text { Housework } \\
\text { Time }\end{array}$ \\
\hline \multicolumn{5}{|l|}{ Human Capital Investment: } \\
\hline Age & $-0.087^{*}$ & & & \\
\hline Education & $0.229 *$ & -1.573 & -0.711 & 0.109 \\
\hline Yrs. worked since 18 & $0.109 *$ & & & \\
\hline \multicolumn{5}{|l|}{ Household Factors: } \\
\hline Husband's wage rate & & $-4.674 *$ & $-2.759 *$ & $0.497 *$ \\
\hline Husband's labor supply & & $5.059 *$ & $2.753 *$ & $-0.148 *$ \\
\hline HH nonlabor income & & $-4.826 *$ & $-2.128 *$ & $0.367 *$ \\
\hline HH housing consump. & & 0.314 & 0.377 & -0.017 \\
\hline $\begin{array}{l}\text { HH home ownership } \\
\text { (dumny) }\end{array}$ & & $15.694 *$ & $7.010 *$ & $-1.599 *$ \\
\hline Husband's d-to-work & & $-2.158 *$ & $-1.122 *$ & $0.116 *$ \\
\hline \multicolumn{5}{|l|}{ Child Effect: } \\
\hline$\#$ of children 2 & & -5.570 & -2.518 & 0.386 \\
\hline 非 of children 3-6 & & 5.066 & -2.290 & 0.352 \\
\hline \# of children $7-18$ & & $-1.531 *$ & $-0.684 *$ & $0.156 *$ \\
\hline \multicolumn{5}{|l|}{ Local Economic Condition: } \\
\hline Unemployment rate & & 0.015 & 0.006 & -0.001 \\
\hline Reference Group Effect: & & & & \\
\hline $\begin{array}{l}\text { Deviation from } \\
\text { group mean }\end{array}$ & & $0.351 *$ & $0.157 *$ & $-0.036 *$ \\
\hline
\end{tabular}


TABLE IX--Continued

\begin{tabular}{|c|c|c|c|c|}
\hline & \multicolumn{4}{|c|}{ Wife's } \\
\hline & $\begin{array}{l}\text { Potential } \\
\text { Wage Rate }\end{array}$ & \multirow[t]{2}{*}{$\begin{array}{l}\text { Labor } \\
\text { Supply }\end{array}$} & \multirow[t]{2}{*}{$\begin{array}{c}\text { Commuting } \\
\text { Time }\end{array}$} & \multirow[t]{2}{*}{$\begin{array}{c}\text { Housework } \\
\text { Time }\end{array}$} \\
\hline Place of Residence: & & & & \\
\hline North Central (dummy) & & $-4.148 *$ & $-1.400 *$ & $-0.132 *$ \\
\hline South (dummy) & -0.560 & $-1.637 *$ & $-0.684 *$ & $-0.118 *$ \\
\hline West (dummy) & 0.330 & $4.963 *$ & $1.419 *$ & $-0.676 *$ \\
\hline CBD2 (dummy) & 1.016 & $12.398 *$ & $5.806^{*}$ & $-0.874 *$ \\
\hline CBD3 (dummy) & & -6.721 & -3.063 & 0.417 \\
\hline CBD4 (dummy) & & -0.652 & -2.825 & 0.130 \\
\hline CBD5 (dummy) & & $-154.778 *$ & $-91.472 *$ & $11.403^{*}$ \\
\hline City size & -0.217 & 2.950 & 1.241 & -0.209 \\
\hline Wife's Wage Rate & & $20.696 *$ & $10.089 *$ & $-1.339 *$ \\
\hline \multicolumn{5}{|l|}{ Wife's Labor Supply } \\
\hline \multicolumn{5}{|l|}{ Wife's Commuting Time } \\
\hline \multicolumn{5}{|l|}{ Wife's Housework Time } \\
\hline Constant & 3.517 & $-22.876 *$ & $-15.019 *$ & $6.226 *$ \\
\hline
\end{tabular}

*Significant at the 0.05 significance level 
Wage and Human Capital Investment

The estimates of this equation have the correct signs and the expected significance based on the human capital investment theory. Both education and experience have significant positive effects on women's potential market wage. While the effects of these human capital investment factors are controlled, the age variable exhibits a depreciating effect which has a significant negative effect on the potential wage. The depreciating effect of age may come from lower physical ability or from the economy's changing production process which makes the human capital investment made in the ealier years out of date. The "place of residence" factors do not have significant effect on women's wage rates. This result seems to be a contradiction of what most regional scientists or urban economists would have expected and also contrary to the result of some empirical studies. Two possible causes contributing to this result are: first, the measurement scale used in this dataset, which divides continental America into only four regions is too aggregated. The "ecological fallacy" phenonmenon resulting from the aggregation is thus large enough to prevent a significant result. Second, the significant spatial variation in the wage rate suggested by other empirical studies may be due to a locational difference in demographic factors, such as the average educational level, the job turnover rate, age, etc. While these factors are controlled in the model here, there is not much variation (of wage rate) left to be explained by the place of residence variables. 
The significant negative effect of education on housework time in the white household group supports the speculation that education will also increase women's home productivity. Another explanation may be that education tends to increase the women's distaste for housework. However, the fact that the absolute value of the education effect in the housework equation is much smaller than that in the wage equation confirms the argument that the prevailing educational discipline tends to increase market productivity more than home productivity (Michael, 1973).

\section{Household Factors}

The husband's wage rate and labor supply have positive effects on the housework time of female household members. This is consistent with what the household production theory has suggested. That is, since the husband's wage rate is an indicator of his relative market productivity to home productivity, a higher market wage will, as a result of the household decision, motivate him to devote more time to market work to the point where the household marginal utility of income is equal to the household marginal utility of his leisure. If a certain amount of housework has to be shared between the husband and the wife, a higher market productivity of the husband or, relatively a lower market productivity of the wife makes the household demand more of the wife's domestic service since the marginal income generated by her in the market would be lower. In essence, the significance of the husband's influence on the woman's time devoted to housework justifies the existence of the division of labor within a household. The significant positive effects of the same factors on the women's 
time devoted to the market seems to imply that, when husbands have higher earnings, the households become more and more consumptionoriented, which then induces a higher household demand for income and thus motivates the female household members to work in the market. Household non-labor income has, in both household groups, a positive effect on a wife's market labor. This result is in contrast to what Becker (1963) suggested that non-labor income should have a negative effect on labor supply since it has a "pure" income effect. Since the amount of asset accumulated depends on the previous incomeearning behavior, the non-labor income as measured here may represent an index of the taste for market work or the different levels of household consumption. If this argument is valid, there would be no measurement of real "non-labor" income which is exogenous to the labor supply decisions and warrants a pure income effect in the context of studying labor supply behavior. The estimated small but significant positive effect of a household's non-labor income on the wife's housework time in the white household group may be a result of the measurement problem. Non-labor income, defined as interest, dividend, or rental income, is not really pure non-labor. Some work still needs to be done to manage these assets. The time spent on this kind of management activity is generally counted as a part of housework time--maybe because it is usually done at home. The resulting positive effect of this management time may override the negative pure income effect, which helps to explain why the net effect of non-labor income is so small in absolute value. In the non-white household group we can expect this type of management time, which is supposed to be a positive function of the household accumulated capital, does not 
exert a significant influence on the amount of the women's housework time and, as a result, the income effect becomes dominating and a negative net effect is empirically derived. There is a possible source of bias affecting the estimate of the non-labor income effect. In the PSID survey, the head-wife relationship is defined by a couple having organized the household and lived together, rather than by the existence of a legal marriage relationship. The eligibility of a person for certain transfer payments, which is mainly determined by the individual's (legal) marriage status, is thus not detected in the model. If these kinds of transfer payments (e.g., ADC/AFDC) are considered as possible sources of non-labor income, the estimate of the effect of non-labor income on women's labor behavior as derived in this study may be biased. Since the individuals in the low-income group are most likely the recipients of the transfer payments, ignoring these sources of non-labor income would bias the estimate upward. However, the data show that only $3 \%$ of the households received the $\mathrm{ADC} / \mathrm{AFDC}$ payment and, as a result, the magnitude of the bias, if it exists, is not expected to be very significant. A further discussion of the effect of transfer payments on women's labor behavior will be raised in the final section of Chapter VI.

The significant negative effect of the home-ownership variable on the women's labor supply does not support the speculation that female household members are generally treated as secondary workers in the households. For if women were secondary workers, the tax benefit resulting from owning a house would motivate them to work in the market because their earnings in this situation would be subject to 
a lower tax rate or, in other words, their after-tax wages would be much higher if the households owned a home. The insignificant and the significant negative effects of this variable in white and nonwhite household groups respectively run counter with this infezence. On the other hand, this empirical result, coupled with the significant negative effect of the household housing consumption on the women's housework time, indicates that the households at different income levels have different consumption patterns of the market goods. In other words, both variables (i.e., housing consumption and home ownership) here become the indicators of household income level. The husband's distance-to-work variable has a negative effect on the female labor supply in both groups and a negative effect on the women's housework time in the white household group. In the case of labor supply, this variable seems to measure the job opportunities locally available. That is, if the husband's workplace corresponds to where the local major employment center is located, the farther a household is located from this center, the less likely its female household member(s) is/are going to get a sufficient amount of job offers in the local area. In this sense, the negative effect of this variable on the women's labor supply behavior describes the constraints that the spatial establishments impose on the local potential female labor suppliers. The negative effect of this variable on the women's housework time is not readily explainable. The theory of urban residential location suggests that the husband's distance to work is a function of the household income and its corresponding preference for living space. Since most of the factors affecting 
a household's demand for living space have been included in the model, what is left to be explained may be the household's special preference for the country life or for the local amenities in the outlying area, Ceteris Paribus. In other words, this variable may measure the household's (including its female members') demand for the leisure, which thus exerts negative effects on "both" the labor supply and the housework time of the female household member(s).

The Wage (Price) Effect

The pathology of the wage effects on the women's labor supply, commuting time, and housework time is indicated in Figure 5.1.

Women's potential market wage rate has a significant positive effect on their labor supply (in both groups) and commuting time (the black household group only).

White

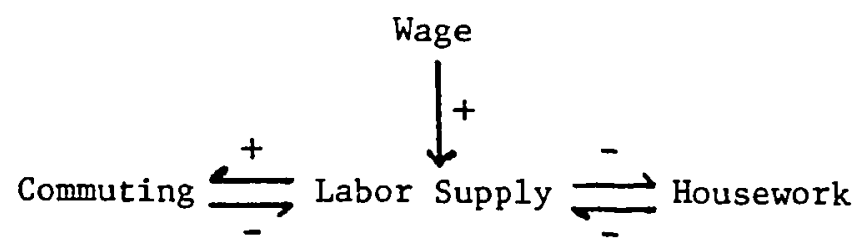

\section{Non-white}

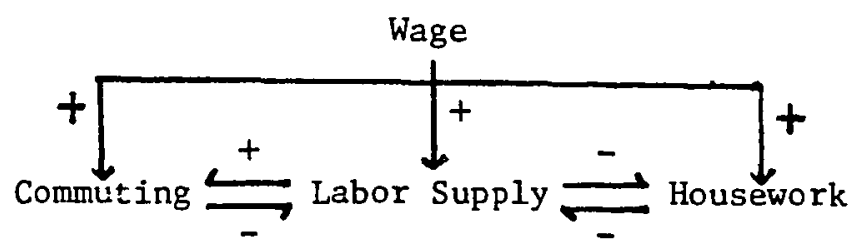

Figure 5.1. The pathology of the significant wage effects. (SOURCE: Table VI and Table VII) 
The positive wage effect on women's labor supply shows that women are generally still at the upward portion of their (backwardbent) labor supply curves. This cross-sectional result is hence consistent with the conclusion of a positive wage effect that most time series studies on female labor supply have derived.

Wage rate, although it exerts no direct effect in the white household group (Table VI) has a positive net effect on the women's commuting time (Table VIII). From the structural relationship shown in Table VI we can see that this positive wage effect is an indirect one. That is, when a higher wage rate induces a higher labor supply, the resulting higher revenue (i.e., higher income) persuades the household to be willing to give away its female member's time for necessary commuting time. This empirical result has an important implication; namely, the employment opportunities which provide higher wages are generally located at a farther distance from the residential locations. The positive direct wage effect on women's commuting in the non-white model supports this speculation, since it means that the households are generally willing to let their female members devote more time for commuting in order to obtain higher wages.

The positive direct effect of women's labor supply on commuting time is consistent with what the urban residential location theory has suggested, that households with higher incomes tend to live in the outlying areas for more spacing and thus are committed to longer commuting distances. However, if we treat the household residential location as exogenously given, or mainly a function of the husband's employment location and income, the empirical fact indicated by this 
positive effect means that women are in general largely constrained by the job opportunities locally available, so they have to commute longer distances in order to obtain a sufficient amount of work, and thus income at a given wage rate.

The net wage effect on the women's time devoted to housework is negative in both groups because it measures the women's relative market productivity with reference to their home productivity, combined with its indirect effect on the labor supply. The significance pattern shown in Figure 5.1 indicates that housework and labor supply are direct substitutes to each other, and that the household demand for a woman's domestic services only indirectly affects her commuting time, if any, through its effect on the amount of her market labor supply. For the non-white household group, the positive direct wage effect on the women's time devoted to the domestic services is not readily explained by the established theoretical framework, even though the net effect is a negative one (Table IX). Tentatively, this empirical result is speculated to reflect the change in the household consumption pattern. If this is true, it implies that in the nonwhite households, female household members with higher market productivity tend to be more exploited through the household joint decisions. Here, the "level of exploitation" is defined in terms of an individual's leisure consumption with respect to his or her income.

In summing up the discussions above, it becomes evident that, in studying the household demand for women's labor supply and housework, we must distinguish that the change in this behavior is driven by price factors (i.e., wage or market productivity) from that driven 
by the change in the household demand for market consumption. In terms of the household production theory, this means the households are located on different output or income levels. For those households located at the same income level, the price or relative productivity decides the desired amount of market or housework of a female household member; and for the household located at higher income levels, the absolute amounts of all input factors (including market labor supply and housework) demanded will be increased. Also, if the households demand a higher level of income or consumption, the empirical evidence here suggests that women, while devoting more time to both market labor and housework or domestic services, may have to reduce a certain amount of leisure time; or, in other words, they may have to shift from comsuming the more time-intensive to the more capital-intensive kinds of leisure goods.

The wage and the spatial elasticities of the women's supply, and the wage and the labor elasticities of commuting time are given in Table $X$. Since the regression coefficient of the double-log functional form directly approximates the elasticity measurement, these figures are directly summarized from Table VI (for labor supply and spatial elasticities), and from Table VIII and Table IX (for wage elasticities). The wage elasticity of labor supply for the white household group is compatible with other studies in the field (e.g., Boskin, 1973). Translating the elasticity measurement into the actual measurement units: a 10-cent increase in the wage rate will, on the average, increase the amount of labor force supply by 23.3 and 854.6 hours/year 
TABLE $X$

THE WAGE AND SPATIAL ELASTICITIES OF THE WOMEN'S LABOR SUPPLY, AND THE WAGE AND LABOR ELASTICITIES

OF THE COMMUTING TIME

(evaluated at the means)

\begin{tabular}{lcc}
\hline & Labor Supply & Commuting \\
\hline White & 0.67 & 0.40 \\
Wage & -2.28 & \\
Commuting & & 0.94 \\
Labor Supply & & 10.09 \\
Non-white & 20.70 & 0.46 \\
Wage & 0 & \\
Commuting & & \\
Labor supply & & \\
\hline
\end{tabular}

for the white and non-white housewives respectively. And, a 10-cent increase in the wage rate will, on the average, increase the amount of commuting time by 1.3 and 33.7 hours/year, for the white and nonewhite housewives respectively, Ceteris Paribus.*

There are two possible explanations for the larger magnitudes of the wage elasticities of labor supply and commuting time for the non-white household group: first, behavior (or decisions) of the households in this group is price-sensitive due to their generally lower income status; and second, since this group is composed of the

* Refer to Appendix $C$ for the mean values of wages, labor supply, and commuting time, for the white and none-white household groups, in order to calculate these figures. 
households of several ethnic backgrounds, the estimation is more likely subject to a specification bias resulting from the existence of the heterogeneity with respect to the female labor supply behavior.

\section{The Child Effect}

The child effect does not significantly affect the women's housework time in both models. This result is compatible with other studies which suggested that women's timing of entering or re-entering into the market labor force seems to have become earlier and earlier, even prior to the entering of children in school. As a long-term consequence of this trend, it is not surprising to find that the appearance of young children in the household no longer produces a significant pulling force which makes the household highly value the woman's domestic services. Of course, the identification of this behavior must be supported by the sustaining of the prevalent availability of childcare facilities outside the household. However, the presence of children ages seven to 18 years old does have a significant effect on the women's labor supply. This result is expected as the capital-intensive characteristics of children in this age group tend to generate higher household demand for the monetary income.

\section{The Reference Group Effect}

The deviation of the husband's household income from the mean income of his reference group exerts a significant and negative effect on women's labor supply and commuting time in both white and non-white models. This result is anticipated by the reference group theory which suggests that households will adjust their behavior to match 
the typical lifestyle of their reference group. In terms of income, the reference group effect can be interpreted in that a household will adjust its members' labor supply status and its consumption behavior in order to match the typical income and consumption pattern of its reference group(s). This result is also consistent with the conclusion of most cross-sectional empirical studies of female labor supply. The deviation variable used in the model is derived from multiplying the husband's wage rate by the corresponding amount of labor supply and then subtracting the product from the mean income of the occupational group to which he belongs. So this variable is in fact measuring the effect of a husband's income on his wife's labor supply, commuting, and housework time. The result can then be interpreted in the following way: the closer a household head's income is to the mean (head's) income of households of the same socio-economic status, the less a wife's market labor or her market income is demanded by the household.

While income-earning behavior alone may not be sufficient to prove that the reference group effect is in operation within a household, the cross-tabulation of husbands' and wives' (actual or expected) occupations in Tables XI and XII, provides convincing evidence that most wives select occupations no lower than their husbands, especially in white households. This result is identical to the argument of the reference group theory that the female household members' labor status will always be carefully chosen so as not to lower a household's socio-economic status as a whole. 
TABLE XI

THE CROSS-TABULATION OF WIVES' OCCUPATIONS BY HUSBANDS' OCCUPATIONS (WHITE)

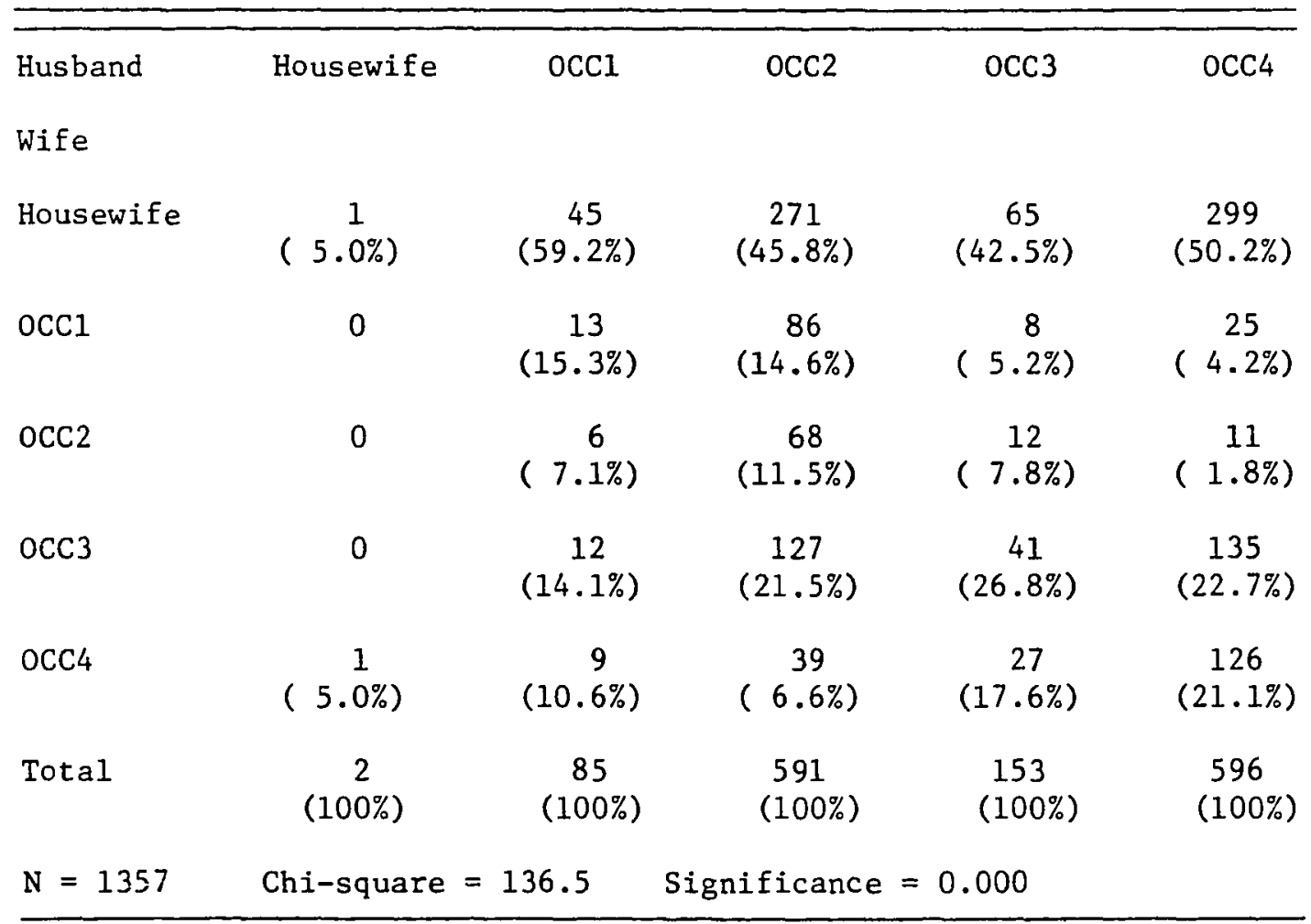

OCCl: Service workers, unskilled laborers OCC2: Operatives and kindred workers, craftsmen and foremen OCC3: Sales workers, clerical and kindred workers 0CC4: Professional and technical workers, managers, officials and proprietors (except farm) 
TABLE XII

THE CROSS-TABULATION OF WIVES' OCCUPATIONS

BY HUSBANDS' OCCUPATIONS (NON-WHITE)

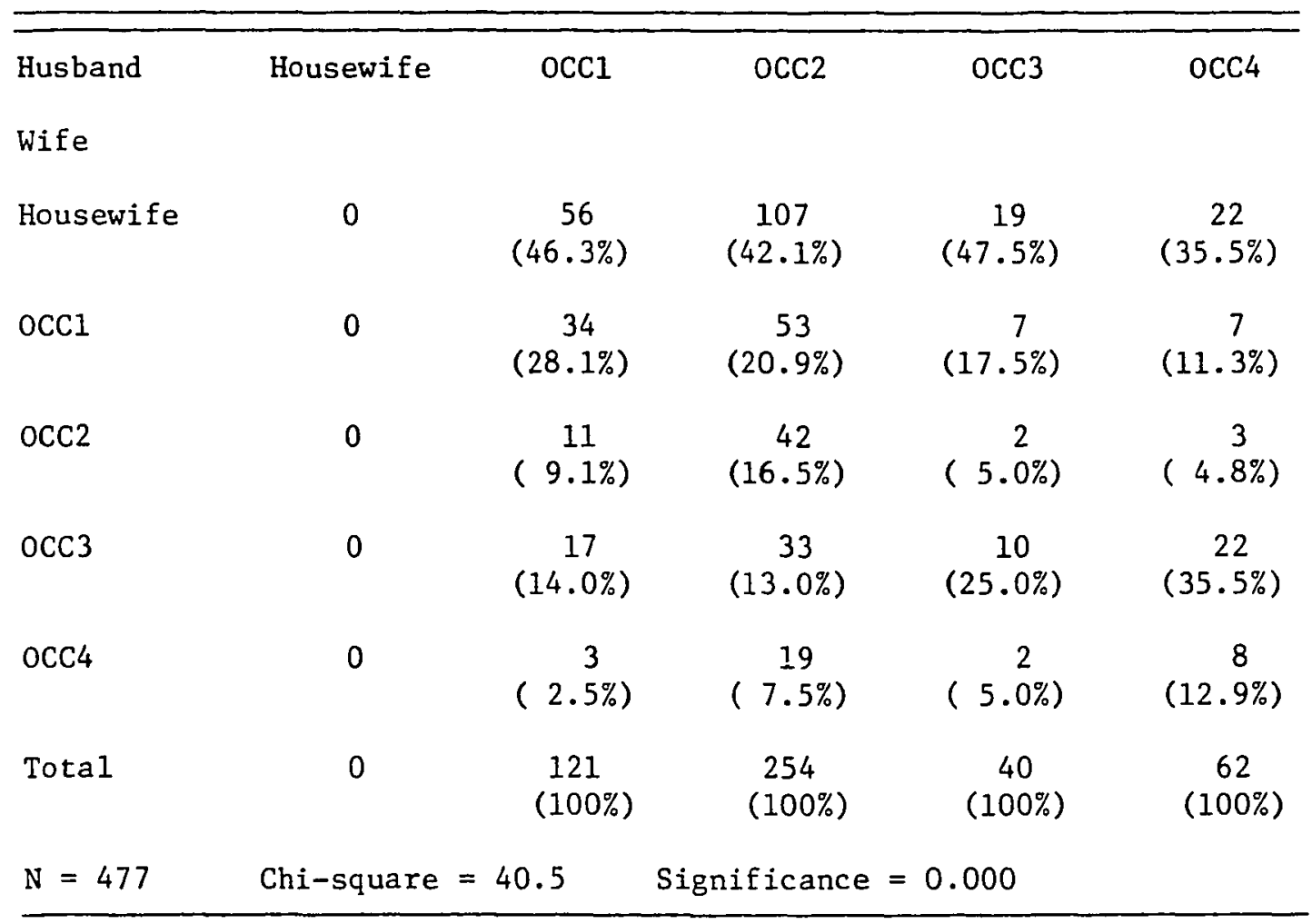

OCC1: Service workers, unskilled laborers

OCC2: Operatives and kindred workers, craftsmen and foremen

OCC3: Sales workers, clerical and kindred workers

0CC4: Professional and technical workers, managers, officials and proprietors (except farm) 


\section{Local Economic Environment}

The country's unemployment rate is rather crude as an indicator of the local economic environment, even though it is combined with the location variables in the model. This variable is not significant in the model. The result does not support the hypothesis that women are treated by households as temporary or marginal income earners. For, if women served as a bumper-like function in the households' adjustment process to market-conditions, a positive effect of the local unemployment rate on the labor supply could be expected. However, this inference is tentative because the possible non-linear relationship between labor supply and unemployment rate, due to the "threshold" effect discussed in Chapter II, is not captured by the way the model is specified in this study.

\section{The Location Factors}

The "place of residence" variables are included in the model to control the spatial variation in other factors affecting the women's labor supply, commuting, and housework behavior. For the women's labor supply, these variables may reveal information about the difference in the local industrial mix, the local welfare system, the size of the local labor pool and the net labor migration, and the job opportunities as perceived by women, etc. For the women's commuting behavior, these variables may in combination reveal information about the characteristics of the local transportation system, or in other words, the women's accessibility to job opportunities at certain distances. For the women's housework time, these variables may indicate the existence of spatial variation in childcare costs and 
in the market price (i.e., the level of the availability of other housework). In Appendix D and Appendix E, preliminary analyses of the effects of these variables on mode choice, commuting time, and childcare costs have been presented. Although some simple nonrandom relationships have been found, most of the variables do not show any significance in the model estimated here. The only noticeable pattern is that, for the white households living in the West region, and for non-white households living in the North Central, South, and West regions, a significantly smaller number of the women's market labor is demanded than those living in the Northeast region. To sum up, the "place of residence" variables do not explain a significant portion of the variance of the dependent variables in the model. However, this result is not inconsistent with other empirical studies. For example, Kunston (1974), in his study on women's labor behavior using National Longitudinal Survey data, derived the same conclusion that location variables do not exert a significant effect. 


\title{
CHAPTER VI
}

\author{
CONCLUSION
}

This study strives for a more comprehensive approach to studying women's labor and commuting behavior by considering the household as a unit in which economic and human resources are pooled and consumption decisions are jointly made. The empirical results presented in Chapter $V$ support most of the Propositions elicited in Chapter II, thereby assuring the consistency of this research with other economic and sociological studies in the field. More importantly, the results support the major contention made in Chapter I that the labor supply and commuting decisions of female workers are made jointly.

In Chapter I, theoretical reasoning was introduced to explain how the estimates of a single-equation model may suffer from a simultaneous equation bias. The argument is empirically supported in this study not only by the statistical significance of the labor supply and commuting variables when they appear in the right-hand side of the equations, but also by the structural interrelation identified by the empirical estimates. For example, for the white household group, wage as an exogenous variable exerts direct and indirect effects on commuting. While the direct effect of the (potential) wage rate on women's commuting behavior is not significant, the indirect effect of wage on the female worker's commuting time is a positive one because the revenue--i.e., income--it generates through more labor supply persuades people to accept more commuting time when needed. This effect has been recognized in 
other research (e.g., Moses \& Williamson, 1970). Obviously, a reduced, one-equation model can hardly distinguish these two elements of the wage effect.

Also, the empirical evidence shows that both wage and commuting time are important price factors (i.e., benefit and cost) affecting the female labor supply decision, assuming that the relative spatial distribution of job opportunities and household residential locations are predetermined. The analytical framework established in this study thus suggests the necessity and the possibility for firms to evaluate the difference in labor cost incurred by electing different spatial locations.

\section{IMPLICATIONS FOR THE LABOR ECONOMY}

The causal relationship between the various forms of human capital investments and the women's labor and commuting behavior has been studied through the construction of the individual's potential wage rate serving as an indicator of the attractiveness of market job opportunties. All of the human capital investment variables, including education and experience, have a positive and significant effect on the women's market labor supply. In recognizing the trend of females to acquire more and more education, in absolute terms or relative to the males average education level, we can expect a higher proportion of women to enter into the labor market field at the beginning stage of their working life cycle. The work experience accumulated during this earlier stage usually means that they have a higher probability of being employed outside the home afterwards. Furthermore, an intergenerational effect may appear since research has shown that the level 
of the parents' human capital investment has a positive effect on the human capital investment of their children (e.g., Kagan \& Moses, 1959; Leibowitz, 1974; Kreps, 1976), and that the mother's working status will positively affect her daughter's attitude toward market work and labor behavior in the future.

The decreased importance of the child effect in the female labor decision is clearly shown by the empirical research result here. This means, on one hand, that women have become more willing to give up childcare activities; and, on the other hand, the market substitutes for childcaring are generally provided at sufficiently low prices for households to be able to purchase these services with the additional income brought into the household by the female worker(s). However, from the public or the producer's perspective, this kind of service should be ensured if more female labor is desired.

Two well-recognized demographic trends occurring in the last two decades have been the increase in the number of households, and the reduction of the average household size. Both phenomena point to a trend of an increasing number of adult males and females organizing households and living independently, with fewer children involved. If this is the case, we can then be led to anticipate an increasing proportion of the female population to participate in the labor market since the average household's pulling force (i.e., the average reservation wage) which prevents women from leaving home is being reduced, Ceteris Paribus. Another contention which supports this inference comes from the general change in the attitude toward the women's labor behavior. Many sociological behavioral studies have 
identified a dramatic, non-reversable change in attitude concerning the desire of women to achieve greater autonomy or independence, and also in the attitude of households toward the female labor status since the 1950s. In addition to that directly identified by the survey questions, facts such as the improvement of the educational level of women in all age groups and the infiltration of more and more women into traditionally male-dominated occupations support the contention. The feedback effects between behavior and attitude can be readily explained by the reference group theory and is supported by empirical studies: when more and more women have been involved in the labor market, the resultant changes in the household consumption pattern puts the status of those households without working wives at a socio-economic disadvantage through a social comparative process, and thus motivates more originally non-working women to enter into the labor market in order to earn monetary income for their households to cope with the prevailing "social standards." An important implication of this inference is that households in general will become more consumption-oriented when their income increases. While the trend toward a "companionship" type of marriage relationship has been recognized for many decades (e.g., Burgess, 1948), research (e.g. Vanek, 1980) has suggested that this trend, if it exists, must have developed in a very gradual manner. In other words, the changes in the division of labor within the households has not been as significant as that in the female labor supply. However, the empirical results derived in this study show that the husband's relative market productivity and labor supply do have significant effects on his partner's time spent in housework. The implication is that the division of labor 
within a household can now be more readily explained by the economic theory of household production.

The above discussions all give positive testimony to a trend of increasing female participation in the labor market. The enactment of equal employment opportunity laws tends to accelerate this process. Demand shortage, as a possible counteracting force, historically has proved to be temporary in nature. However, the role of demand as a source of creating temporary fluctuations on the upward trend of the female labor force participation rate should not be ignored in investigations or forecasting analyses focusing on short-run changes.

\section{IMPLICATIONS FOR THE URBAN ECONOMY}

The role of the husband in the household has already been widely discussed in sociological literature, namely that he will not, at least in the near future, alter his traditional role in the household regardless of his wife's labor status. Taking for granted this argument, coupled with the empirical result of this study that the wife's labor supply has a significant negative effect on her housework time, it can then be inferred that changes are likely to occur in the household consumption pattern of market goods as a result of the increasing female labor force supply to the market. Thus, an increasing demand on some housework services in the market can be expected, especially those activities which are time-consuming, rigidly scheduled, or in need of heavy tools or strength. For example, childcare is both time-consuming and rigid in schedule while some household maintenance work, such as cleaning and repairing, requires physical strength, and heavy tools. Both 
of these are the most probable candidates to be substituted by market services.

From the producer's perspective, the changing female labor supply, commuting, and housework behavior have some important implications. First, the subsequent changes in the household consumption pattern as discussed above may affect either the optimum level of production of individual firms or the number of participants in the industries. Consequently, these two effects might result in a new locational pattern of the firms involved. This locational effect may be particularly significant for those market-oriented industries--e.g., the service industry. Second, the resulting change in the household consumption pattern may stimulate the evolution of the production of "convenient" goods or services. The evolution of the localized grocery store networks such as 7-Eleven and Plaid Pantry provides a good example. The spatial distribution of these new services will thus greatly depend on the pattern of the household residential location and on the pattern of the labor supply of female household members. Third, the significant effect of commuting on labor supply behavior suggests that, within a metropolitan area, a new firm should take into consideration both the spatial distribution of demographic characteristics and the characteristics of the job opportunity it is going to provide in order to recruit enough labor, female in this case, at a certain wage level. The significance of this spatial effect on a firm's location choice depends on the (female) labor-intensiveness of the prevailing production technology adopted by the firm or the industry concerned. 
Traditional transportation demand analysis has long been criticized for ignoring household or demographic factors. To neglect these factors in any travel demand analysis is "(1) to risk being seriously wrong in future predictions or (2) to freeze in time the relationship observed" (Rosenbloom, 1978). This study provides an improvement in this respect by treating all female household members as potential workers and then studying the spatial characteristics of their labor supply activity. In most transportation capital investment projects, cost-benefit or cost-effectiveness analyses are required to evaluate the proposals. Time saving effects resulting from the construction of a proposed project should be estimated in an unbiased way, since it is usually viewed as the major benefit or the major goal of the project to the public. Traditional cost-benefit analysis as applied to transportation investment projects generally made efforts to estimate the benefit resulting from the time saving of current travelers but rather arbitrarily estimated the benefit pertaining to the project-induced new users. One major reason is that data is more readily obtainable on those current travelers. As the results of this study have suggested, a systematic examination of the relative spatial distribution of the job opportunities and the demographic characteristics within a local area may help identify those new users of a transportation investment project-at least the female workers in the case concerned. That is, a demand analysis incorporating this consideration will give a much more precise forecast of the induced demand and thus a more unbiased evaluation of the proposed transportation investment project. 


\section{DISCUSSION}

The contentions raised in the beginning of this study have been empirically supported throughout this research, and some important implications have been addressed in this chapter. Generally speaking, theoretical refinements have been implemented and methodological improvements have been employed, thereby deriving a more unbiased and precise description of the female labor supply and commuting behavior. However, some possible sources of bias may still be imbedded in the theoretical framework, model construction, and estimation method of this study. A full recognition of these critical weaknesses helps identify the areas for further investigation in the field concerned. First, this analysis takes for granted that a household 's residential location is decided exogenously to its female member's labor supply and commuting decisions. This postulate is consistent with the generally recognized condition that the husband's employment location is more important than the wife's, if any, in the determination of the household's place of residence. Thus, the validity of the arguments derived from the results of this analysis relies heavily on the household preference structure being sustained. The trend toward a companionate type of relationship within the household has been developing at a fairly slow rate. Consequently, we can anticipate that in the near future the husband's employment location will continue to be predominant in the household decision regarding its place of residence. However, some consumer research and surveys have shown that more and more women have been involved in the household consumption decision of mid- and long-range durable goods, such as automobile and housing 
consumption (e.g., Duker, 1970). As the women's decision-making power within the household has increased to a certain extent, and as the market labor and commuting time of female household members are given more and more weight in the household decision process, treating household location as exogenously determined may be unrealistic in the study of the female labor supply and commuting behavior. What is implied in this situation is that the household residential location choice and housing consumption are then functions of the female household member's labor behavior. The model should then be reconstructed to take into account the endogeny of these two variables.

Second, the disaggregation according to (the husband's) occupation should be given serious consideration because, as has been discussed in Chapter II, it can help separate households of different socio-economic status which either have varying preference structures, or may be subject to different environmental constraints or the particular perference of different employers. Also, segmenting the non-white household group into subgroups of different racial origins, and then estimating the model for each subgroup may help derive more reliable estimates.

Third, a major shortcoming of this study is that the effect of the cost of commuting is not fully maintained because, in addition to the commuting time, various levels of monetary cost may be induced by adopting different modes of transportation. It was originally hoped that the effect of this cost element could be indirectly captured by some location variables included in the model and for this purpose a preliminary analysis has been done in Appendix D. However, a more 
comprehensive approach should include the modal choices as endogenous variables and thus expand the equation system. This means a more sophisticated model and estimation procedure are needed--e.g., adding a multiple discrete-choice set of equations (simulating the modeselection behavior) to the original equation system and re-formulating the whole equation system to explore the structural inter-relationship among labor supply, commuting time and modal choice.

Fourth, the low $\mathrm{R}^{2}$ 's for the labor supply equations may be the signal indicating the possible discontinuity of the true labor supply behavior. The discontinuity of the labor supply behavior occurs when there exists an acceptable minimum amount of market work hours for which women are willing to change their labor status from home to the labor market. So, a model using a continuous function to approximate this discontinuous labor supply behavior would have poorer performance. The significance of this discontinuity effect on the performance of the model is decided by the magnitude of this minimum working level, if it exists. Based on the consideration described, it may be worth the effort to devise a more viable working model to empirically test the existence of this discontinuity phenomenon.

Fifth, it has been argued that there are some common preference elements imbedded in the error terms of the wage and labor supply equations. If this does occur, the determination of an individual's potential wage should be endogenous to his or her labor supply behavior. Empirically, full information maximum likelihood method (FIML) has been employed to estimate this kind of model and a tentative conclusion is derived; that is, the non-worker's potential wage rate tends to be 
overestimated when the estimation is made using a wage equation calibrated on worker's data. This empirical result seems to suggest the demand for further theoretical work toward identifying these "common" preferential elements which cannot or have not been explicitly measured.

Sixth, although the use of after-tax wage is used in this study to internalize the effect of income tax, as a kind of negative transfer payment, by assuming that each individual could precisely calculate his/her marginal tax rate and thus adjust his/her market labor supply accordingly, the consideration of other sources of transfer payment is excluded for two reasons: first, there have been no persuasive empirical findings which testify to the importance of transfer payment in affecting an individual's work effort; and second, since the amount of transfer payment received is mainly a function of wage rate, labor supply, and age, it should thus be treated as an endogenous variable to be explained. The relationship between labor supply and transfer payment is very complicated with respect to its dynamic nature and to its heterogeneity--for example, the differential effects of the restricted and the unrestricted transfer payments. The prices paid for the efforts to model this complicated relationship is, in general, unjustifiable. However, there are some circumstances in which modelling the effect of the transfer payment is the main purpose of the research, for example, a study designed to analyze the effects of the negative income tax experiment. With a view to this possible demand, the construction of a labor supply model which incorporates the consideration of transfer payment receipt may be an area worth exploring. 
Seventh, the existence of the "cohort effect," that women in different age groups may bear differential attitudes toward market jobs, should not be neglected. So, a more rigid approach should be used to estimate the model for each age group. If the "cohort effect" did significantly exist, the inclusion of age variable in the wage equation in this study might result in a biased estimate, since its appearance brings about a correlation between wage variable and error term in the labor supply equation. For the purpose of deciding a more accurate model specification, segmenting population into cohort groups and comparing the parameter estimates between groups to detect the significance of this cohort effect may help clarify the confusion. The above discussion identifies the potential demands for the more flexible and the more comprehensive models. These models, which at least provide the opportunity for a closer approximation to the real-world behavioral pattern, are generally preferential. But the feasibility of its implementation depends on whether the gains obtained from developing a more versatile model can justify the higher costs incurred. These costs may include further theoretical exploration, more data for calibration, and higher computing costs, etc. As the empirical results of this study have suggested, a labor supply model exclusive of the variability in commuting, or a commuting model exclusive of the consideration of the corresponding change in labor behavior will deviate from the real situation to a significant extent, at least in the female case. Then, should the same procedure be incorporated into any research in the related field? According.ly, the decision must be made by evaluating the higher costs incurred and the specific purpose(s) the research is designed to achieve. 
BIBLIOGRAPHY

Agarwala, R. and Drinkwater, J. (1972) "Consumption Functions With Shifting Parameters Due to Socio-Economic Factors." Review of Economics and Statistics 54:89-96.

Alonso, W. (1964) Transportation and Land Use. Cambridge: Harvard University Press.

Alonso, W. (1967) "A Reformulation of Classical Location Theory And Its Relation to Rent Theory." Papers and Proceddings of Regional Science Association 19:23-44.

Amsden, A. H. (ed.). (1980) The Economics of Women and Work. New York: St. Martin's Press, Inc.

Andrulis, J. (1982) "Intra-Urban Workplace and Residential Mobility Under Uncertainty." Journal of Urban Economics 11:85-97.

Ashenfelter, D. and Heckman, J. (1974) "The Estimation of Income and Substitution Effects in a Model of Family Labor Supply." Econometrica 42, 1:73-85.

Baker, S. H. and Levenson, B. (1975) "Job Opportunities of Black and White Working-Class Women." Social Problems 22:510-533.

Barrett, N. S. (1976) "The Economy Ahead of Us: Will Women Have Different Roles?" in Juanita M. Kreps (ed.), Women and the American Economy: A Look to the 1980's. Englewood Cliffs, N.J.: Prentice-Hall, Inc.

Baucroft, G. (1958) The American Labor Force: Its Growth and Changing Composition. New York: John Wiley \& Sons, Inc.

Becker, G. S. (1962) "Investment in Human Capital: A Theoretical Analysis." Journal of Political Economy 70, 5, 2:9-49.

Becker, G. S. (1965) "A Theory of the Allocation of Time." The Economic Journal 80:493-517.

Beesley, M. E. (1965) "The Value of Time Spent in Traveling: Some New Evidence," in R. E. Quandt (ed.), The Demand for Travel: Theory and Measurement, pp. 221-234. Lexington, Mass.: D. C. Heath and Company.

Bell, C. S. (1974) "Working Women's Contribution to Family Income." Eastern Economic Journal 1:185-201. 
Be11, C. S. (1977) "Women and Work: An Economic Appraisal." in A. H. Stromberg and S. Harkess (eds.), Women Working. Palo Alto, CA: Mayfield.

Benston, M. (1969) "The Political Economy of Women's Liberation." Monthly Review 21:13-27.

Berk, R. A. and Berk, S. F. (1978) "A Simultaneous Equation Model For the Division of Household Labor." Sociological Methods and Research 6 (May): 431-468.

Berk, R. and Berk, S. F. (1979) Labor and Leisure at Home: Content and Organization of the Household Day. Beverly Hills, CA: Sage Publications.

Berk, R. A. (1980) "The New Home Economics: An Agenda for Sociological Research," in Sarah Berk (ed.), Women and Household Labor. Beverly Hills, CA: Sage Publications.

Berkowitz, M. and Johnson, G. W. (1974) "Health and Labor Force Participation." The Journal of Human Resources 9:117-128.

Berry, B. J. L. (1973) The Human Consequences of Urbanization. New York: St. Martin's Press.

Bish, R. L. and Nourse, H. O. (eds.). (1975) Urban Economics and Policy Analysis. Glenview, Illinois: Scott, Foresman and Co.

Bish, R. L. \& Kirk, R. J. (1974) Economic Principles and Urban Problems. Englewood Cliffs, NJ: Prentice-Hall, Inc.

Bose, C. (1980) "Social Status of the Homemaker," in Sarah Berk (ed.), Women and Household Labor. Beverly Hills, CA: Sage Publications.

Boskin, J. J. (1973) "The Economics of Labor Supply," in G. G. Cain and H. W. Watts (eds), Income Maintenance and Labor Supply. New York: Academic Press.

Boskin, J. J. (1974) "The Effects of Government Expenditures and Taxes on Female Labor." American Economic Review 64, 2:251-256.

Boulding, E. (1979) "Family Wholeness: New Conception of Family Roles," in K. W. Feinstein (ed.), Working Women and Families, pp. 277-91. Beverly Hills, CA: Sage Publications.

Bowen, W. G. and Finegan, T. A. (1965) "Labor Force Participation and Unemployment," in A. M. Ross (ed.), Employment Policy and the Labor Market. Beverly Hills and Los Angeles: University of California Press. 
Bowen, W. G. and Finegan, T. A. (1969) The Economics of Labor Force Participation.

Burgess, E. W. (1948) "The Family in a Changing Society." The American Journal of Sociology $54: 118-124$.

Cain, G. C. (1966) Married Women in the Labor Force: An Economic Analysis. Chicago: University of Chicago Press.

Caplow, T. (1954) The Sociology of Work. Minneapolis: University of Minnesota Press.

Carrol, M. S. (1962) "The Working Wife and Her Family's Economic Position." Monthly Labor Review 854:366-374.

Chafe, W. H. (1976) "Looking Backward in Order to Look Forward: Women, Work and Social Values in America," in Juanita M. Kreps (ed.), Women and the American Economy: A Look to the 1980's. Englewood Cliffs, NJ: Prentice-hall, Inc.

Chapin, F. S., Jr. (1974) Human Activity Patterns in the City: Things People Do in Time and Space. New York: John Wiley.

Cherlow, J. R. and Morgan, J. N. (1976) "Commuting Time and Speed," in G. J. Duncan and J. N. Morgan (eds.), Five Thousand American Families: Pattern of Economic Progress vol. 4, Chapter 10. Ann Arbor, MI: Institute for Social Research.

Cherlow, J. R. (1981) "Measuring Values of Travel Time Saving." Journal of Consumer Research 7, 2:360-371.

Chiplin, B. and Sloave, P. J. (1974) "Sexual Discrimination in the Labor Market." British Journal of Industrial Relations, 12: $371-402$.

Cramer, J. C. (1973) "Births, Expected Family Size, and Poverty," in G. J. Duncan and J. N. Morgan (eds.), Five Thousand American Families: Pattern of Economic Progress, pp. 279-317. Ann Arbor, MI: Institute for Social Research.

Cramer, J. C. (1980) "Fertility and Female Employment: Problems of Causal Direction." American Sociological Review 45, 2: 167-190.

Cripps, F. (1977) "The Money Supply, Wage and Inflation." Cambridge Journal of Economics 1, 2:101-112.

Curran, C., Leonard, A. C. and David, A. F. (1982) "A Theory of Residential Location Decisions of Two-Worker Household." The Journal of Urban Economics 12:102-114. 
Darley, S. A. (1976) "Big-Time Career for the Little Woman: A Dual-Role Dilemma." Journal of Social Issues 32:85-98.

Denney, R. and Riseman (1951) "Leisure in Urbanized America," in P. K. Hatt and A. J. Reiss (eds.), Reader in Urban Sociology.

Desalvo, J. S. and Eeckhoudt, L. R. (1982) "Household Behavior Under Income Uncertainty in a Monocentric Urban Area." Journal of Urban Economics 11:98-111.

DeVaney, B. (1983) "An Analysis of Variation in U. S. Fertility Female Labor Force Participation Trends. Demography, 20, 2: 147-161.

Doeringer, P. B. (1967) "Determinants of the Structure of Industrial Type Labor Markets." Industrial and Labor Relation Review 20:206-220.

Duesenbery, J. S. (1949) Income, Saving, and the Theory of Consumers Behavior. Cambridge, Mass.: Harvard University Press.

Duker, J. A. (1970) "Housewife and Working-Wife Families: A Housing Comparison." Land Economics 46:138-145.

Duncan, B. and Duncan, D. D. (1978) Sex Typing and Social Roles: A Research Report. New York: Academic Press.

Eberts, R. W. and Gronberg, T. J. (1982) "Wage Gradients, Rent Gradients, and the Price Elasticity of Demand for Housing: An Empirical Investigation." Journal of Urban Economics 12: 168-176.

Eckstein, O. and Brinner, R. (1976) "The Inflation Process in the United States," in 0. Eckstein (ed.), Parameters and Policies in the U. S. Economy, pp. 99-158. New York: American Elsevier Publishing Company, Inc.

Edwards, R. C., Reich, M., and Gordon, D. M. (eds.). (1975) Labor Market Segmentation. Lexington, Mass.: D. C. Heath.

Epsenshade, T. J. (1977) "The Value and Cost of Children." Population Bulletin 32, 1:1-41.

Fales, R. L. and Moses, L. N. (1972) "Land Use Theory and the Spatial Structure of the Nineteenth Century City." Papers and Proceedings of Regional Science Association 28:49-80.

Farkas, G. (1976) "Education, Wage Rate, and the Division of Labor Between Husband and Wife." Journal of Marriage and Family $3: 473-484$. 
Feinstein, K. W. (ed.). (1979) Working Women and Family. Beverly Hills, CA: Sage Publications.

Feldstein, M. and EcKstein, 0. (1976) "The Fundamental Determinants of the Interest Rate," in 0. Eckstein (ed.), Parameters and Policies in the U. S. Economy, pp. 76-98. New York: American Elsevier Publishing Company, Inc.

Felmlee, D. H. (1984) "A Dynamic Analysis of Women's Employment Exits." Demography 21, 2:129-140.

Ferber, R. and Lee, L. C. (1974) "Use of Time as a Determinant of Family Market Behavior." Journal of Consumer Research 1:43-50.

Ferber, M. A. and Birnbaum, B. G. (1977) "The New Home Economics Retrospects and Prospects." Journal of Consumer Research.

Ferree, M. M. (1976) "Working Class Jobs: Housework and Paid Work as Sources of Satisfaction." Social Problems 23 (April):431-441.

Ferree, M. M. (1980) "Satisfaction With Housework: The Social Context," in Sarah Fenstermaker Berk (ed.), Women and Household Labor. Beverly Hills, CA: Sage Publications.

Festinger, L. (1954) "A Theory of Social Comparison Process." Human Relations 7, 1:117-140.

Foner, P. S. (1979) Women and the American Labor Movement. New York: The Free Press.

Fox, M. B. (1983) "Working Women and Travel." The Journal of American Planning Association 49, 2:156-170.

Friedman, M. (1957) A Theory of the Consumption Function. Princeton: Princeton University Press.

Fuchs, V. R. (1974) "Recent Trends and Long-Run Prospects for Female Earnings." American Economic Review 64:236-242.

Fuchs, V. R. (1983) How We Live. Cambridge: Harvard University Press.

Fullerton, H. N. (1980) "The 1995 Labor Force: A First Look." Monthly Labor Review 103, 12:11-21.

Ginzberg, E. (1979) Good Jobs, Bad Jobs, No Jobs. Cambridge: Harvard University Press.

Glazer, N. (1976) "Housework." Signs 1, 4:905-921.

Glazer, N. (1980) "Everyone Needs Three Hands: Doing Unpaid and Paid Work," in S. F. Berk (ed.), Women and Household Labor. Beverly Hills, CA: Sage Publications 
Glick, P. and Norton (1977) "Marrying, Divorcing, and Living Together in the U. S. Today." Population Bulletin 32:1-41.

Goldner, W. (1955) "Spatial and Locational Aspects of Metropolitan Labor Markets." American Economic Review 45:111-128.

Goodman, A. C. and Kawai, M. (1982) "Permanent Income, Hedonic Prices, and Demand for Housing: New Evidence." Journal of Economics 12:214-237.

Gramm, W. (1975) "Household Utility Maximization and the Working Wife." American Economic Review 65:90-100.

Gray, B. M. (1971) "Economics of Sex Bias." The Nation, (May): 742-744.

Gray, B. M. (1971) "Sex Bias and Cyclical Unemployment." The Nation, 212:742-744.

Greenhut, M. L. (1952) "Integrating the Leading Theories of Plant Location." Southern Economic Journal 18, 4:526-538.

Griffin, L. J. (1977) "On Estimating the Economic Value of Schooling and Experience." Sociological Method and Research 6, 2:309-336.

Gronan, R. (1974) "The Effects of Children on the Housewife's Value of Time," in T. W. Schultz (ed.), Economics of the Family: Marriage, Children, and Human Capital. Chicago: University of Chicago Press.

Gronau, R. (1973) "The Effect of Children on the Housewife's Value of Time." The Journal of Political Economy 81: 168-199.

Gronau, R. (1977) "Leisure, Home Production and Work: The Theory of the Allocation of Time Revisited." Journal of Political Economy 85:1099-1124.

Gubbels, R. (1968) "The Supply and Demand for Women Workers," in N. Glazer-Malbin and H. Y. Waehrer (eds.), Women in ManMade World. New York: Rand McNally and Company.

Hall, R. E. (1970) "Why is the Unemployment Rate So High at Full Employment?" Brookings Papers on Economic Activity 3:369-410.

Hamburger, W. (1955) "The Relation of Consumption to Wealth and the Wage Rate." Econometrica 23, 1:1-17.

Hanham, R. W. and Chang, H. (1981) "Wage Inflation in a Growth Region: The American Sun Belt," in R. L. Martin (ed.), Regional Wage Inflation and Unemployment, pp. 75-95. London: Page Pion Ltd. 
Hanoch, G. (1980) "Hours and Weeks in the Theory of Labor Supply," in J. P. Smith (ed.), Female Labor Supply: Theory and Estimation, pp. 119-165. Princeton: Princeton University Press.

Hanoch, G. (1980) "A Multivariate Model of Labor Supply: Methodology and Estimation," in J. P. Smith (ed.), Female Labor Supply: Theory and Estimation, pp. 249-325. Princeton: Princeton University Press.

Hansen, W. L. (1961) "Cyclical Sensitivity of the Labor Force." American Economic Review 51, 3:299-309.

Hatch, M. G. and Hatch, D. L. (1968) "Problems of Married Working Women as Presented by Three Popular Working Women's Magazines." Social Forces 37:148-159.

Hauser, P. M. (1954) "Mobility in Labor Force Participation," in Labor Mobility and Economic Opportunity, Pref. by P. Webbink. Cambridge: The M.I.T. Press.

Hawrylyshyn, O. (1976) "The Value of Household Services: A Survey of Empirical Estimates." The Review of Income and Wealth 22: 101-131.

Hayghe, H. (1976) "Family and the Rise of Working Wives--An Overview." Monthly Labor Review 99, 5:12-19.

Heckman, J. (1974) "Shadow-Prices, Market Wages, and Labor Supply." Econometrica 42, 4:679-694.

Heckman, J. J. (1980) "Sample Selection Bias as a Specification Error," in J. P. Smith (ed.), Female Labor Supply: Theory and Estimation, pp. 206-248. Princeton: Princeton University Press.

Hedges, J. N. and Barnett, J. K. (1972) "Working Women and the Division of Household Tasks." Monthly Labor Review 95 (Apri1): 9-14.

Heilbrun, J. (1981) Urban Economics and Public Policy. New York: St. Martin's Press, Inc.

Heese, S. J. (1979) "Women Working: Historical Trend," in K. W. Feinstein (ed.), Working Women and Families, pp. 33-62. Beverly Hills, CA: Sage Publications.

Hoffman, S. and Holmes, J. (1976) "Husbands, Wives and Divorce," in G. J. Duncan and J. N. Morgan (eds.), Five Thousand American Families: Patterns of Economic Progress vol. 4, Chapter 2. Ann Arbor, MI: Institute for Social Research. 
Hotelling, H. (1929) "Stability in Competition." Economic Journal $39: 41-57$.

Jones, R. C. (1960) "Transitory Income and Expenditures on Consumption Categories." American Economic Review 50, 2:584-592.

Jusenius, C. L. (1977) "The Influence of Work Experience, Skill Requirement, and Occupational Segregation on Women's Earnings." Journal of Economics and Business 29:107-115.

Kagan, J. and Moses, H. A. (1959) "Parental Correlates of Child's I. Q. and Height." Child Development 30, 3:325-332.

Kahn, R. (1972) "The Meaning of Work: Interpretations and Proposals for Measurement," in A. Campbell and P. Converse (eds.), The Human Meaning of Social Change, pp. 159-204. New York: Russell Sage.

Kain, J. F. (1962) "The Journey to Work as a Determinant of Residential Location." Papers and Proceedings of Regional Science Association, 137-160.

Kasper, H. (1983) "Toward Estimating the Incidence of Journey-to Work Choice." Urban Studies 20:197-208.

Keer, C. (1954) "The Balkanization of Labor Markets," in E. W. Bakke (ed.), Labor Mobility and Economic Opportunity. Cambridge: Technology Press of M.I.T.

Kerlinger, F. N. (1964) Foundations of Behavioral Research. New York: Holt, Rinehart and Winston, Inc.

Killingsworth, M. R. (1983) Labor Supply. Cambridge: Cambridge University Press.

Kish, L. and Frankel, M. R. (1970) "Balanced Repeated Replications For Standard Errors." The Journal of Anerican Statistical Association 65, 331:1071-1093.

Kostyniuk, L. P. and Cleveland, D. E. (1978) "Gender-Role Identification in the Methodology of Transportation Planning." Women's Travel Issues: Research Needs and Priorities, pp. 569-606. U. S. Department of Transportation.

Kreps, J. M. (ed.). (1976) Women and the American Economy: A Look to the 1980's. Englewood Cliffs, NJ: Prentice-Hall, Inc.

Kreps, J. M. and Leaper, J. (1976) "Home Work, Market Work and the Allocation of Time," in J. M. Kreps (ed.), Women and the American Economy: A Look to the 1980's, pp. 61-81. Englewood Cliffs, NJ: Prentice-Hall, Inc. 
Kunston, M. A. (1974) A Woman in the Labor Force: Factors Affecting Both Her Labor Force Decision and the Time She is Willing to Supply in the Labor Market. M. S. Thesis, Oklahoma State University.

Ladner, J. A. (1972) Tomorrow's Tomorrow: The Black Woman. New York: Doubleday and Co.

Lancaster, K. J. (1966) "A New Approach to Consumer Theory." Journal of Political Economy 74, 1:132-157.

Laws, J. L. (1971) "A Feminist View of Marital Adjustment Literature: The Rape of the Loche." The Journal of Marriage and the Family $33: 483-516$.

Lazear, R. P. and Michael, R. T. (1980) "Real Income Equivalence Among One-Earner and Two-Earner Families." Papers and Proceedings of American Economic Association 70:203-208.

Lehrer, E. and Nerlove, M. (1980) "Women's Life-Cycle Time Allocation: An Econometric Analysis," in Sara F. Berk (ed.), Women and Household Labor. Beverly Hills, CA: Sage Publications.

Leibowitz, A. (1974) "Education and Home Production." American Economic Review, 64, 2:243-256.

Lester, R. A. (1946) "Shortcomings of Marginal Analysis for WageEmployment Problems." American Economic Review 36.

Levinson, R. M. (1975) "Sex Discrimination and Employment Practices: An Experiment With Unconventional Job Inquiries." Social Problems $22: 533-543$.

Lglehart, A. P. (1979) Married Women and Work. Washington, D.C.: Heath.

MacRae, D., Jr. (1976) The Social Function of Social Science. New York: Yale University Press.

Maddala, G. S. (1983) Limited-Dependent and Qualitative Variables in Econometrics. New York: Cambridge University Press.

Madden, J. F. (1977) "An Empirical Analysis of the Spatial Elasticity of Labor Supply." Papers and Proceedings of Regional Science Association 39:157-171.

Madden, J. F. (1980) "Urban Land Use and the Growth in Two-Earner Households." Papers and Proceedings of American Economic Association 70:191-197. 
Madden, J. F. (1981) "Why Women Work Closer to Home." Urban Studies $18: 181-194$.

Madden, J. N. and M. J. White (1980) "Spatial Implications of the Increase in the Female Labor Force." Land Economics 56, 4:432-445.

Mahoney, T. A. (1961) "Influences on Labor-Force Participation of Married Women," in N. N. Foote (ed.), Household Decision Making, pp. 11-24. New York: New York University Press.

Mahoney, T. A. (1961) "Factors Determining the Labor Force Participation of Married Women." Industrial and Labor Relation Review 14, 4:563-577.

Maisel, S. J. (1966) "Rates of Ownership, Mobility, and Purchase," in Essays in Urban Land Economics, pp. 76-107. Real Estate Research Program, University of California Press.

Matthaei, J. A. (1980) "Consequences of the Rise of the Two-Earner Family: The Breakdown of the Sexual Division of Labor." Papers and Proceedings of American Economic Association 70: 198-202.

McClintock, C. (1983) "The Telecommuting Adventure." Human Ecology Forum 13:3-6.

McMillan, T. E. (1965) "Determinants of Plant Location." Land Economics 41, 3:239-246.

Merton, R. K. and Kitt, A. S. (1950) "Contributions to the Theory of Reference Group Behavior," in R. K. Merton and P. F. Lazarsfeld (eds.), Continuities in Social Research: Studies in the Scope and the Method of "The American Soldier." Glencoe, Ill.: Free Press.

Merton, R. K. (1957) Social Theory and Soc1al Structure. Glencoe, I11.: Free Press.

Michael, R. T. (1972) The Effects of Education on Efficiency in Consumption. New York: N.B.E.R.

Michael, R. T. (1973) "Education in Nonmarket Production." The Journal of Political Economy 81, 2:306-327.

Michael, R. T. and Becker, G. S. (1976) "On the New Theory of Consumer Behavior," In G. S. Becker (ed.), The Economic Approach to Human Behavior. Chicago: University of Chicago Press.

Mills, E. S. (1972) Urban Economics. Glenview, Ill.: Scott, Foresman and Co.

Mincer, J. (1960) "Labor Supply, Family Income and Consumption." Papers and Proceedings of American Economic Association 50, 2: 574-583. 
Mincer, J. (1962) "Labor Force Participation of Married Women: A Study of Labor Supply, in National Bureau of Economic Research, Aspects of Labor Economics, pp. 63-105. Princeton: Princeton University Press.

Mincer, J. (1963) "Market Price, Opportunity Costs, and Income Effect," in Measurements in Economics. Stanford: Stanford University Press.

Mincer, J. (1966) "Labor-Force Participation and Unemployment: A Review of Recent Evidence," in Robert A. Gordon and Margaret Gordon (eds.), Prosperity and Unemployment, pp. 73-112. New York: John Wiley and Sons.

Mincer, J. (1974) Schooling, Experience, and Earnings. New York: National Bureau of Economic Research.

Mincer, J. and Polachek, S. (1974) "Family Investment in Human Capital: Earnings of Women." Journal of Political Economy 82: 976-1108.

Moore, K. A. and Sawhill, I. V. (1976) "Implications of Women's Employment for Home and Family Life," in Juanita M. Kreps (ed.), Women and the American Economy: A Look to the 1980's. Englewood Cliffs, NJ: Prentice-Hall, Inc.

Moses, L. (1962) "Towards a Theory of Intra-Urban Way Differentials and Their Influence on Travel Patterns." Papers and Proceedings of Regional Science Association 9:53-62.

Moses, L. and Williamson, H. F. (1967) "The Location of Economic Activity in Cities." American Economic Review, 211-241.

Moses, L. N. and Williamson, H. F. (1970) "Value of Time, Choice of Mode, and Subsidy Issue in Urban Transportation," in R. E. Quant (ed.), The Demand for Trave1, pp. 197-220. Lexington, Mass.: Lexington Books.

Mott, F. L. (1979) "Racial Difference in Labor Force Participation: Trends and Implications for the Future, in K. W. Feinstein (ed.), Working Women and Families, pp. 85-102. Beverly Hills, CA: Sage Publications.

Muth, R. F. (1969) City and Housing. Chicago: University of Chicago Press.

Nelson, L. B. (1980) "Household Time: A Cross-Cultural Example," in Sarah F. Berk (ed.), Women and Household Labor. Beverly Hills, CA: Sage Publications.

Nelson, P. (1973) "The Elasticity of Labor Supply to Individual Firm." Econometrica 41:853-866. 
Nickell, S. (1979) "Education and Lifetime Pattern of Unemployment." Journal of Political Economy, 117-131.

Niemi, B. (1974) "The Female-Male Differential in Unemployment Rates." Industrial and Labor Relation Review 27, 3:331-350.

Oppenheimer, V. K. (1970) The Female Labor Force in the U.S.: Demographic and Economic Factors Determining Its Growth and Changing Composition. Population Monograph Series No. 5. Berkeley: Institute of International Studies, University of California.

Oppenheimer, V. K. (1973) "Demographic Influence on Female Employment and the Status of Women," in John Huber (ed.), Changing Women in a Changing Society. Chicago: University of Chicago Press.

Oppenheimer, V. K. (1982) Work and the Family. New York: Academic Press, Inc.

O.E.C.D. (1976) "The 1974-1975 Recession and the Employment of Women."

Orden, S. R. and Bradburn, N. M. (1969) "Working Wives and Marriage Happiness." American Journal of Sociology 74, 4:392-407.

Orr, L. L. (1975) Income, Employment, and Urban Residential Location. New York: Academic Press, Inc.

Orski, C. K. (1982) "The Changing Environment of Urban Transportation." The Journal of American Planning Association 49, 2:156-170

Parson, D. 0. (1977) "Health, Family Structure, and Labor Supply." American Economic Review 67:703-712.

Parson, D. 0. (1980) "The Decline in Male Labor Force Participation." Journal of Political Economy 88, 1:117-134.

Phelps, C. D. (1972) "Is the Household Obsolete?" Papers and Proceedings of American Economic Association 62:167-174.

Pifer, A. (1979) "Women Working: Toward a New Society," in K. W. Feinstein (ed.), Working Women and Families, pp. 13-34. Beverley Hills, CA: Sage Publications, Inc.

Pigou, A. C. (1943) "The Classical Stationary State." Economic Journal 53:343-351.

Pollak, R. A. and Wachter, M. L. (1975) "The Relevance of the Household Production Function and Its Implications for the Allocation of Time." Journal of Political Economy 83:255-277.

Predoh1, A. (1928) "The Theory of Location in Its Relation to General Economics." Journal of Political Economy 36:371-390. 
Pynn, C. S. (1969) "The Monetary Value of a Housewife." American Journal of Economics and Sociology 28:271-284.

Quarmby, D. A. (1967) "Choice of Travel Mode for the Journey to Work: Some Findings." Journal of Transport Economics and Policy $1: 1-42$.

Quinlan, D. C. and Shackelford, J. A. (1980) "Labor Force Participation Rates of Women and the Rise of the Two-Earner Family." Papers and Proceedings of the Ninety-Second Annual Meeting of the American Economic Association 70:209-212.

Radloff, R. (1966) "Social Comparison and Ability Evaluation," in B. Latame (ed.), Studies in Social Comparison. New York: Academic Press.

Ratchford, B. T. (1975) "The New Economic Theory of Consumer Behavior: An Interpretive Essay." The Journal of Consumer Research 2.

Rees, A. and Schultz, G. P. (1970) Workers and Wages in an Urban Labor Market. Chicago: The University of Chicago Press.

Reich, M., Gordon, D. M., and Edwards, R. C. (1973) "A Theory of Labor Market Segmentation." American Economics Review 63:359-365.

Reid, M. G. (1977) "How New is the 'New Home Economics'?" Journal of Consumer Research 4, 3:181-183.

Richardson, H. W. (1973) Regional Growth Theory. London: Macmillan Press, Lt.

Rima, I. H. (1981) Labor Market Wages, and Employment. New York: W. W. Norton and Company, Inc.

Robinson, J. P. (1977) "The New Home Economics: Sexist, Unrealistic, or Simply Irrelevant?" Journal of Consumer Research 4, 3:178-181.

Robinson, J. P. (1980) "Housework Technology and Household Work," in S. F. Berk (ed.), Women and Household Labor. Beverly Hills, CA: Sage Publications.

Rogoff, N. (1951) "Recent Trends in Urban Occupational Mobility," in P. K. Hatt and A. J. Reiss (eds.), Reader in Urban Sociology.

Rosen, H. S. (1980) What is Labor Supply and Do Taxes Affect It?" American Economic Review 70:171-175.

Rosenbloom, S. (1978) "Women's Travel Issues: The Research and Policy Environment," in Women's Travel Issues: Research Needs and Priorities. U. S. Department of Transportation. 
Rosett, R. (1958) "Working Wives: An Econometric Study," in Thomas F. Derbert et al. (eds.), Studies in Household Economic Behavior, pp. 51-100. New Haven: Yale University Press.

Ross, H. L. and Sawhill, I. V. (1975) Time of transition: The Growth of Families Headed by Women. Washington, D. C.: The Urban Institute.

Rubery, J. (1978) "Structured Labor Markets, Worker Organization and Low Pay." Cambridge Journal of Economics 2:17-36.

Rushton, G. (1969) "Analysis of Spatial Behavior by Revealed Space Preference." Annals of the Association of American Geographers $59,2: 391-400$.

Sampson, W. A. and Ross, H. (1975) "Race and Family Social Standing." American Sociological Review $40: 201-214$.

Sawhill, I. V. (1977) "Economic Perspectives on the Family." Journal of the American Academy of Arts and Sciences 106:115-125.

Scanzoni, J. (1977) "Changing Sex Roles and Emerging Directions in Family Decision Making." The Journal of Consumer Research 4: 185-188.

Schultz, T. P. (1980) "Estimating Labor Supply Functions for Married Women," in J. P. Smith (ed.), Female Labor Supply: Theory and Estimation, pp. 25-89. Princeton: Princeton University Press.

Scott, J. W. and Tilly, L. A. (1975) "Women's Work and the Family in Nineteenth-Century Europe." Comparative Studies in Society and History $17: 36-64$.

Sen, A. (1978) "On the Labor Theory of Value: Some Methodological Issues." Cambridge Journal of Economics 2:175-190.

Shishko, R. and Rostker, B. (1976) "The Economics of Multiple Job Holding." American Economic Review 66, 3:298-308.

Skinner, L. E. and Boriaug, K. L. (1978) "Shopping Trips: Who Makes Them and When?" in Women's Travel Issues: Research Needs and Priorities, pp. 105-126. U. S. Department of Transportation.

Smith, J. P. (1979) "The Distribution of Family Earnings." Journal of Political Economy 87, 5:163-192.

Smith, J. P. (ed.) . (1980) Female Labor Supply: Theory and Estimation.

Smith, R. E. (1979) "Hours Rigidity: Effects on the Labor-Market Status of Women," in K. W. Feinstein (ed.), Working Women and Families, Pp. 211-222. Beverly Hills, CA: Sage Publications, Inc.

Smithies, A. (1941) "Optimum Location in Spatial Competition." Journal of Political Economy 49:423-439. 
Sorokin, P. A. and Berger, C. A. (1939) Time-Budget of Human Behavior. Cambridge: Harvard University.

Spielberg, F. and Stephen, A. (1982) "The Implications of Demographic Changes on Transportation Policy." The Journal of American Planning Association 48, 3:301-308.

Stein, R. J. (1969) "Facts About Women's Absenteeism and Labor Turnover," in N. Glazer-Malbin and H. Y. Waehrer (eds.), Women in Man-Made World. New York: Rand McNally and Company.

Stein, R. J. (1970) "The Economic Status of Families Headed by Women." Monthly Labor Review 93:3-9.

Stevens, B. J. (1979) "Employment, Permanent Income and the Demand For Housing." The Journal of Urban Economics 6:480-500.

Stolzenberg, R. M. and Waite, L. J. (1984) "Local Labor Markets, Children and Labor Force Participation of Wives. Demography $21,2: 157-170$.

Strasser, S. M. (1980) "An Enlarged Human Existence? Technology and Household Work in Nineteenth-Century America," in S. F. Berk (ed.), Women and Household Labor. Beverly Hills, CA: Sage Publications.

Strober, M. H. and Weinberg, C. B. (1977) "Working Wives and Major Family Expenditures." Journal of Consumer Research 4:141-147.

Stromberg, A. and Harkess, S. (eds.). (1978) Women Working: Theories and Facts in Perspective. Palo Alto, CA: Mayfield.

Survey Research Center at The University of Michigan. (1980) A Panel Study of Income Dynamics.

Suter, L. and Miller, H. (1973) "Income Differences Between Men and Career Women." American Journal of Sociology 78:962-974.

Sweet, J. A. (1970) "Family Composition and the Labor Force Activity of American Wives." Demography.

Sweet, J. A. (1971) "The Employment of Wives and the Inequality of Family Income." Proceedings of the American Statistical Association, Social Statistics Section, 1-5.

Sweet, J. A. (1973) Women in the Labor Force. New York: Semina.

Sweet, J. A. (1984) "Components of Changes in the Number of Households 1970-1980." Demography 21, 2:129-140.

Taeuber, K. E. and Sweet, J. A. (1976) "Family and Work: The Social Lifecycle of Women," in J. M. Kreps (ed.), Women and the American Economy. Englewood Cliffs, NJ: Prentice-Hall. 
Thompson, W. R. (1960) "Internal and External Factors in the Development of Urban Economics," in H. S. Perloff and L. Wingo (eds.), Issues in Urban Economics. Baltimore: The John Hopkins Press.

Thompson, W. (1965) A Preface to Urban Economics. Baltimore: The John Hopkins Press.

Thourow, L. C. and Lucas, R. B. (1976) "The Distribution of Earned Income," in 0. Eckstein (ed.), Parameters and Policies in the U. S. Economy. New York: American Elsevier Publishing Co.

Tobin, J. (1958) "Estimation of Relationships for Limited Dependent Variables." Econometrica 26:24-36.

U. S. Department of Commerce, Bureau of the Census. (1974) Historical Statistics of the United States: Colonial Time to 1957.

U. S. Department of Commerce, Bureau of the Census. (1982) Current Population Reports: Population Characteristics, Series P-20, No. 380, Marital Status and Living Arrangements: March, 1982.

U. S. Department of Commerce, Bureau of the Census. Statistical Abstract of the United States 1984.

U. S. Department of Health and Human Services. Vital Statistics of the United States 1979, vol. III, Marriage and Divorce.

U. S. Department of Labor, Bureau of the Census. (1979) Current Populacion Reports, Special Studies Series P-23, No. 80, The Social and Economic Status of the Black Population in the United States: A Historical Review 1790-1978.

U. S. Department of Labor, Bureau of the Census. Statistical Abstract of the United States 1980.

U. S. Department of Labor, Bureau of Labor Statistics. (September 1982) Bulletin 2096, Labor Force Statistics Derived From the Current Population Survey: A Databook, vol. I.

U. S. Department of Labor, Bureau of Labor Statistics. (December 1983) Bulletin 2175, Handbook of Labor Statistics 1983.

Ü. S. Department of Transportation. (1978) Women's Travel Issues: Research Needs and Priorities.

Vanek, J. (1974) "Time Spent in Housework." Scientific American $231: 116-120)$.

Vanek, J. (1980) "Household Work, Wage Work, and Sexual Equality," in S. F. Berk (ed.), Women and Household Labor. Beverly Hills, CA: Sage Publications. 
Vietorisz, T. and Harrison, B. (1973) "Labor Market Segmentation: Positive Feedback and Divergent Development." Papers and Proceedings of the Eighty-Fifth Annual Meeting of the American Economic Association, 366-376.

Waldman, E. (1970) "Changes in the Labor Force Activity of Women." Monthly Labor Review 93, 6:10-18.

Wales, T. J. and Woodland, A. D. (1977) "Estimation of the Allocation of Time for Work, Leisure and Housework." Econometrica 45, 1:115-132.

Wales, T. J. (1978) "Labor Supply and Commuting Time." The Journal of Econometrics $8: 215-226$.

Walker, K. E. (1973) "Household Work Time: Its Implications for Family Decisions." Journal of Home Economics (October):7-11.

Walker, K. E. and Gauger, W. H. (1973) The Dollar Value of Housework. Information Bulletin 60, New York State College of Human Ecology, Cornell University.

Walker, K. E. and Woods, M. (1976) Time Use: A Measure of Household Production of Goods and Services. Washington, D. C.: Center for the Family of American Home Economics Association.

Weber, A. (1929) Alfred Weber's Theory of the Location of Industries. Translated by C. J. Friedrich from Uber den Standort der Industrien (1909), University of Chicago Press.

Weiss, L. W. (1966) "Concentration and Labor Earnings." American Economic Review 56, 1:96-117.

Weisskoff, F. B. (1972) "Women's Place in the Labor Market." Papers and Proceedings of American Economic Association 72:161-166.

Wendt, P. F. and Goldner, W. (1966) "Land Values and the Dynamics of Residential Location," in Essays in Urban Land Econonics. Berkeley, CA: University of California Real Estate Research Program, 68-75.

White, M. J. (1977) "A Model of Residential Location Choice and Commuting by Men and Women Worker." Journal of Regional Science $17,1: 41-52$.

Williams, G. (1975) "A Research Note on Trends in Occupational Differentiation by Sex." Social Problems 22:543-547.

Willis, R. J. (1974) "Economic Theory of Fertility Behavior," in T. W. Schultz (ed.), Economics of the Family, pp. 25-72. Chicago: University of Chicago Press.

Wingo, L., Jr. (1961) Transportation and Urban Land. Washington, D. C.: Resource for the Future, Inc. 
Wittner, J. G. (1980) "Domestic Labor as Work Discipline: The Struggle Over Housework in Foster Homes," in S. F. Berk (ed.), Women and Household Labor. Beverly Hills, CA: Sage Publications

Youburg, B. (1974) Sexual Identity: Sex Roles and Social Change. New York: Wiley, Inc. 
APPENDIX A

\section{(1) Nonfarmers}

V6678: Head is farmer or rancher

(2) Household in equilibrium

V6492: If head is unemployed

V6592: If wife is unemployed

V6535-37: If head is employed and wants to work more or less

V6541-42: If head is employed and was seeking new job

V6486: If household is planning to move

(3) Household with female member(s)

V6662: If there is no female member in the household

(4) Household composed of a couple

V6662: If head is male who has wife in household

(5) Nonstudents

V6462: Age of the head

V6464: Age of the wife

V7387: Schooling completed by head, 1980

V7346: Schooling completed by wife, 1980

That is, if V6462 - V7387-5=0 or V6464 - V7387 - 5=0, the observation shall be excluded. 


\section{APPENDIX B}

1. EW; Em (The amount of labor supplied)

V6934: Head's annual working hours

V6946: Wife's annual working hours

2. Tcw (The time demanded by the household for the women's domestic services)

V6963: Annual hours spent by wife on housework

V6965: Annual hours spent by head on housework

V6675: Hours spent per week doing something else in return for childcare

3. $\operatorname{tw}(\mathrm{Tm})$ (The time spent in commuting)

V6944: Head's travel to work time (annual hours)

V6956: Wife's travel to work time (annual hours)

4. $\mathrm{Cm}(\mathrm{Tm})$; $\mathrm{Cw}(\mathrm{Tw})$ (The costs of commuting)

V6773: Region (see 15)

V6306: Size of iargest city in the probability - Sampling

unit where the respondent locates

0. Non-SMSA

1. SMSA: Largest city 500,000 or more

2. SMSA: Largest city $100,000-499,999$

3. SMSA: Largest city $50,000-99,999$

4. SMSA: Largest city $25,000-49,999$

V6470 \& V6471: Distance to CBD of the nearest city (see 10) 
5. rw; rm (Permanent or potential wage rates)

V7417: Average hourly earning of head (in cents)

V7418: Average hourly earning of wife (in cents)

V6546: If unemployed, the wage rate (in cents) expected by head

V7399: Estimated marginal income tax rate of head and wife, jointly

That is, $\mathrm{rw}=\mathrm{v} 7418 *(1-\mathrm{v} 7399)$ and $\mathrm{rm}=\mathrm{v} 7417 *(1-\mathrm{V} 7399)$

or V6566* $(1-V 7399)$.

6. $\mathrm{Ph} * \mathrm{H}$ (Housing consumption)

V6323: If homeowner, annual morgage payment (in dollars)

V6325: If homeowner, annual property tax (in dollars)

V6326: If renter, annual rent (in dollars)

V6929: The imputed rent of free housing for those who neither own nor rent (in dollars)

7. V (Non-wage income)

V6998: Total taxable income of husband and wife--including

labor income, rent, income from nonincorporated business, etc.

V7417: Average hourly earning of head

V7418: Average hourly earning of wife

V6934: Head's annual working hours

V6946: Wife's annual working hours

V7399: Estimated income tax rate of head and wife, jointly

That is, $V=[V 6998-(V 7417 * V 6934+V 7418 * V 6946)] *(1-V 7399)$

(in dollars). 
8. Age2, Age2-6, Age6-17 (The child effect)

V6793: \# of children in the household ages 1-2

V6794: 非 of children in the household ages 2-5

V6795: \# of children in the household ages 6-13

V6797: \# of children in the household ages 14-17

V6671: Hours spent in childcare per week

That is, Age2 $=$ V6793, Age2-6 $=$ V6794, Age6-17 = v6795 + V6797

9. Sch1, Exp, Tran (Human capital investments)

V6713: Wife's education--schooling completed

V6598: Wife's 非 of years worked full time since age 18

V6598: \# of months worked in current job

10. $\mathrm{CBD} 2, \mathrm{CBD} 3, \mathrm{CBD} 4, \mathrm{CBD} 5$ (Distance to $\mathrm{CBD}$ )

V6470: If located inside the city limits, how far is the house from the center of that city?

V6471: If located outside the city limits, how far is the house from the center of the nearest city?

(1. less than 5 miles

2. 5- 14.9 miles

3. $15-29.9$ miles

4. $30-49.9$ miles

5. 50 or more miles)

11. Own (Home ownership)

V6323: Annual morgage payment

That is, 0 wn $=1$ when $v 6323>0$

12. Race

V6802: White, Black, Spanish-American or other

That is, White $=1$ when $V 6802=1$ and Nonwhite $=1$ when $V 6801=1$ 
13. Occupation

V6497: Husband's occupation

V6545: If husband is unemployed, the kind of job looked for

(1. Service workers: unskilled laborers

2. Operatives and kindred workers; craftsmen and foremen

3. Sales workers; clerical and kindred workers

4. Professional and technical workers; managers, officials and proprietors [except farm])

14. MD (The local labor market condition)

V6811: Unemployment rate for the county where respondent is located

15. R2, R3, R4 (Regional difference)

V6773: Region

(1. Northeast

2. North Central

3. South

4. West)

That is, $\mathrm{R} 2=1$ when $\mathrm{V} 6773=2 ; \mathrm{R} 3=1$ when $\mathrm{V} 6773=3$; and $R 4=1$ when $V 6773=4$.

16. City

V6306: Size of the largest city in the area where the household is located

(0. Non-SMSA: Largest city with population under 24,999

1. SMSA: Non-SMSA--Largest city with population $25,000-49,999$

2. SMSA: Largest city with population 50,000 - 99,999 
3. SMSA: Largest city with population 100,000 499,999

4. SMSA: Largest city with population 500,000 or more)

17. DEV (The referent group effect

rm (See 5 of this Appendix)

Em (See 1 of this Appendix)

That is, the husband's mean income (MINi) for each occupational

group $i$ (see 13 of this Appendix is first calculated:

$$
\text { MINi }=\frac{\sum_{i=1}^{N i}(\text { rmi } * \text { Emi })}{N i}
$$

then, DEV $=(\mathrm{rmi} * \mathrm{Emi})-\mathrm{MINi}$ 
APPENDIX C

THE DESCRIPTIVE STATISTICS (WHITE HOUSEHOLD)

\begin{tabular}{lll}
$\begin{array}{c}\text { Measurement } \\
\text { Unit }\end{array}$ & Mean & $\begin{array}{l}\text { Standard } \\
\text { Deviation }\end{array}$ \\
\hline
\end{tabular}

Human Capital Investment:

$\begin{array}{lccc}\text { Age } & \text { Years } & 38.0 & 11.6 \\ \text { Education } & \text { Years } & 12.5 & 2.2 \\ \text { Yrs. worked since 18 } & \text { Years } & 8.5 & 7.5\end{array}$

Household Factors:

$\begin{array}{llcr}\text { Husband's wage rate } & \text { Cents/hr } & 633.7 & 324.5 \\ \text { Husband's labor supply } & \text { Hours/yr } & 2197.2 & 661.4 \\ \text { HH nonlabor income } & \text { Dollars } & 1547.3 & 3456.8 \\ \text { HH housing consump. } & \text { Dollars } & 6173.8 & 3125.3 \\ \text { HH home ownership } & \text { Yes/No } & 0.8 & 0.3 \\ \quad \text { (dumy) } & \text { Miles } & 31.0 & 55.4 \\ \text { Husband's d-to-work } & & \end{array}$

Child Effect:

$\begin{array}{llll}\text { \# of children <2 } & \text { Integer } & 0.23 & 0.46 \\ \text { \# of children 3-6 } & \text { Integer } & 0.21 & 0.46 \\ \text { \# of children 7-18 } & \text { Integer } & 0.86 & 1.08\end{array}$

Local Economic Condition:

$$
\text { Unemployment rate }
$$

$\%$

5.5

2.0

Reference Group Effect:

Deviation from group mean

$\begin{array}{lll}\text { Dollars } & -459.7 & 7279.4\end{array}$




\section{Measurement}

Unit

Place of Residence:

North Central (dummy)
South (dummy)
West (dummy)
CBD2 (dummy)
CBD3 (dummy)
CBD4 (dummy)
CBD5 (dummy)
City size

Endogenous Variables:

Wife's wage rate

Wife's labor supply

Wife's commuting time

Wife's housework time
Yes/No

Yes/No

Yes/No

Yes/No

Yes/No

Yes/No

Yes/No

Integer $(0-4)$

Cents/hr

Hours/yr

Hours/yr

Hours/yr $\underline{\text { Mean }}$

0.3

0.4

0.3

0.4

0.2

0.4

0.2

0.06

0.06

0.01

1.6

0.4

0.4

0.2

0.1

1.3
253.8

319.3

881.5

878.8

57.9

90.1

1530.3

902.2 
THE DESCRIPTIVE STATISTICS (NON-WHITE HOUSEHOLDS)

\begin{tabular}{lll}
$\begin{array}{c}\text { Measurement } \\
\text { Unit }\end{array}$ & Mean & $\begin{array}{l}\text { Standard } \\
\text { Deviation }\end{array}$ \\
\hline
\end{tabular}

Human Capital Investment:

$\begin{array}{lccr}\text { Age } & \text { Years } & 37.8 & 11.1 \\ \text { Education } & \text { Years } & 11.1 & 2.6 \\ \text { Yrs. worked since 18 } & \text { Years } & 9.2 & 8.3\end{array}$

Household Factors:

$\begin{array}{llcr}\text { Husband's wage rate } & \text { Cents/hr } & 611.8 & 611.1 \\ \text { Husband's labor supply } & \text { Hours/yr } & 1977.0 & 667.5 \\ \text { HH nonlabor income } & \text { Dollars } & 251.7 & 1594.4 \\ \text { HH housing consump. } & \text { Dollars } & 5415.7 & 2912.8 \\ \text { HH home ownership } & \text { Yes/No } & 0.6 & 0.5 \\ \quad \text { dummy } & \text { Miles } & 39.3 & 61.1\end{array}$

Child Effect:

$\begin{array}{llll}\text { \# of children <2 } & \text { Integer } & 0.2 & 0.5 \\ \text { \# of children 3-6 } & \text { Integer } & 0.2 & 0.5 \\ \text { \# of children 7-18 } & \text { Integer } & 1.3 & 1.4\end{array}$

Local Economic Condition:

Unemployment rate

$\%$

5.7

1.8

Reference Group Effect:

Deviation from

group mean

Dollars $\quad-1669.0 \quad 6226.1$ 
Measurement Unit

Place of Residence:

North Central (dumny)

South (dummy)

West (dummy)

CBD2 (dummy)

CBD3 (dummy)

CBD4 (dummy)

CBD5 (dummy)

City size

Endogenous Variables:

Wife's wage rate

Wife's labor supply

Wife's commuting time

Wife's housework time

Unit

Yes/No

Yes/No

Yes/No

Yes/No

Yes/No

Yes/No

Yes/No

Integer

$(0-4)$

Cents/hr

Hours/yr

Hours/yr

Hours/yr $\underline{\text { Mean }}$

Standard

Deviation

0.1

0.3

0.7

0.5

0.1

0.3

0.4

0.5

0.07

0.3

0.02

0.1

0.01

0.1

1.3

1.0

244.8

224.3

1010.7

876.6

81.7

104.0

1255.2

940.6 


\section{APPENDIX D \\ COMMUTING TIME, COMMUTING DISTANCE, AND \\ PLACE OF RESIDENCE}

It is generally assumed that the mode of travel decides its speed. Here the breakdowns of commuting time and distance by modal choices may reveal the interrelated pattern of time, distance, and speed.

\begin{tabular}{|c|c|c|c|c|c|c|}
\hline \multirow[b]{2}{*}{$\begin{array}{l}\text { Commuting Time } \\
\text { (annual hours) }\end{array}$} & \multicolumn{3}{|c|}{ White } & \multicolumn{3}{|c|}{ Nonwhite } \\
\hline & Mean & Std. Dev. & $\underline{N}$ & Mean & Std. Dev. & $\underline{\mathrm{N}}$ \\
\hline \multicolumn{7}{|l|}{ Modal Choice } \\
\hline Public trans. & 195.4 & 134.9 & 30 & 180.8 & 146.5 & 32 \\
\hline Drive with Hd. & 110.6 & 89.3 & 72 & 116.8 & 96.7 & 44 \\
\hline Car pool & 152.1 & 142.2 & 46 & 148.8 & 107.8 & 39 \\
\hline Drive by self & 98.4 & 98.1 & 485 & 122.5 & 97.8 & 124 \\
\hline Walk & 36.2 & 29.4 & 25 & 50.3 & 39.4 & 9 \\
\hline Other & 76.3 & 83.2 & 14 & 51.7 & 69.8 & 6 \\
\hline \multirow[t]{2}{*}{ Total } & 105.0 & 104.1 & 672 & 128.7 & 107.5 & 254 \\
\hline & $\begin{array}{l}\text { Betwee } \\
\text { Sig. }=\end{array}$ & \multicolumn{2}{|c|}{ Group $F=9.8$} & \multicolumn{3}{|c|}{ Between Group $F=3.7$} \\
\hline
\end{tabular}




\begin{tabular}{|c|c|c|c|c|c|c|}
\hline \multirow{2}{*}{$\begin{array}{l}\text { Commuting Dist. } \\
\text { (miles) }\end{array}$} & \multicolumn{3}{|c|}{ White } & \multicolumn{3}{|c|}{ Nonwhite } \\
\hline & Mean & Std. Dev. & $\underline{\mathrm{N}}$ & Mean & Std. Dev. & $\underline{\mathrm{N}}$ \\
\hline \multicolumn{7}{|l|}{ Modal Choice } \\
\hline Publc. trans. & 11.6 & 11.3 & 30 & 8.2 & 6.5 & 32 \\
\hline Drive with Hd. & 9.0 & 6.6 & 72 & 6.7 & 4.9 & 44 \\
\hline Car pool & 11.2 & 9.9 & 46 & 12.5 & 9.3 & 39 \\
\hline Drive by self & 7.2 & 6.7 & 485 & 8.0 & 6.7 & 124 \\
\hline Walk & 1.0 & 0.3 & 25 & 1.0 & 0 & 9 \\
\hline Other & 5.3 & 7.9 & 14 & 5.5 & 7.3 & 6 \\
\hline \multirow[t]{2}{*}{ Total } & 7.6 & 7.3 & 672 & 8.2 & 7.1 & 254 \\
\hline & $\begin{array}{l}\text { Betwee } \\
\text { Sig. }=\end{array}$ & $\begin{array}{l}\text { Group } F= \\
0.000\end{array}$ & 9.8 & $\begin{array}{l}\text { Betwe } \\
\text { Sig. }\end{array}$ & $\begin{array}{l}\text { Group } F= \\
0.000\end{array}$ & .7 \\
\hline
\end{tabular}

The above tables show that commuting time and commuting distance are related to modal choice.

While the causal direction between modal choice and commuting time is not definite, the theory of residential location suggests that they be the functions of the place-of-residence choice. The crosstabulation of modal choice by regions, city size, and distance to $C B D$ which follows can provide some primitive evidence. 


\section{White}

Mode*

Region:

Northeast

North

Central

South

West

Total.

SMSA

$>500,000$

SMSA

$100,000-499,999$

123

$\mathrm{N}=672$, Chi-squ. $=32.2$

Sig. $=0.006$

City Size

$5 \quad 7$

Nonwhite

$\begin{array}{llll}3 & 4 & 5 & 7\end{array}$

$\begin{array}{llllllllllll}16 & 17 & 12 & 105 & 7 & 1 & 3 & 2 & 3 & 4 & 6 & 0\end{array}$

$53.3 \% \quad 26.6 \% \quad 26.1 \% \quad 21.6 \% \quad 28.0 \% \quad 7.1 \% \quad 9.4 \% \quad 4.5 \% \quad 9.7 \% \quad 3.2 \% \quad 66.7 \%$

$\begin{array}{cccccccccc}7 & 24 & 14 & 151 & 11 & 6 & 7 & 4 & 3 & 10 \\ 23.3 \% & 33.3 \% & 30.4 \% & 31.1 \% & 44.0 \% & 42.9 \% & 21.9 \% & 9.1 \% & 7.7 \% & 8.1 \%\end{array}$

$\begin{array}{ccccccccccccc}3 & 25 & 17 & 151 & 4 & 7 & 21 & 32 & 28 & 84 & 3 & 5 \\ 10.0 \% & 34.7 \% & 37.0 \% & 31.1 \% & 16.0 \% & 50.0 \% & 65.6 \% & 72.7 \% & 71.8 \% & 67.7 \% & 33.3 \% & 83.3 \%\end{array}$

$\begin{array}{llllllllllll}4 & 6 & 3 & 78 & 3 & 0 & 1 & 6 & 5 & 26 & 0 & 1\end{array}$

$\begin{array}{lllllllllll}13.3 \% & 8.3 \% & 6.5 \% & 16.1 \% & 12.0 \% & & 3.1 \% & 13.6 \% & 12.8 \% & 21.0 \% & 1\end{array}$

$\begin{array}{cccccccccccc}30 & 72 & 46 & 485 & 25 & 14 & 32 & 44 & 39 & 124 & 9 & 6 \\ 100 \% & 100 \% & 100 \% & 100 \% & 100 \% & 100 \% & 100 \% & 100 \% & 100 \% & 100 \% & 100 \% & 100 \%\end{array}$

$\mathrm{N}=254$, Chi-squ. $=65.1$

Sig. $=0.000$ 
White

\begin{tabular}{|c|c|c|c|c|c|c|c|c|c|c|c|c|}
\hline Mode* & 1 & 2 & 3 & 4 & 5 & 7 & 1 & 2 & 3 & 4 & 5 & 7 \\
\hline $\begin{array}{c}\text { SMSA } \\
50,000-99,999\end{array}$ & 0 & $11.7 \%$ & ${ }^{4} .7 \%$ & $\begin{array}{l}77 \\
15.9 \%\end{array}$ & $\begin{array}{l}1 \\
4.0 \%\end{array}$ & 0 & 0 & 0 & 0 & $\begin{array}{l}7 \\
5.6 \%\end{array}$ & 0 & 0 \\
\hline $\begin{array}{c}\text { SMSA, NONSMSA } \\
25,000-49,999\end{array}$ & 0 & $\begin{array}{l}7 \\
9.7 \%\end{array}$ & $\stackrel{2}{4.3 \%}$ & $\begin{array}{l}34 \\
7.0 \%\end{array}$ & $16.0 \%$ & ${ }^{1} .1 \%$ & 0 & $2.3 \%$ & 0 & $\begin{array}{l}10 \\
8.1 \%\end{array}$ & $22.2 \%$ & 0 \\
\hline $\begin{array}{c}\text { NONSMSA } \\
10,000-24,999\end{array}$ & 0 & $\begin{array}{l}10 \\
13.9 \%\end{array}$ & $17.4 \%$ & $\begin{array}{c}60 \\
12.4 \%\end{array}$ & $8.0 \%$ & $28.6 \%$ & 0 & ${ }^{3} .8 \%$ & $23.1 \%$ & $\begin{array}{l}6 \\
4.8 \%\end{array}$ & 0 & $33.3 \%$ \\
\hline $\begin{array}{l}\text { NONSMSA } \\
10,000\end{array}$ & 0 & $\begin{array}{l}7 \\
9.7 \%\end{array}$ & $13.0 \%$ & $\begin{array}{l}74 \\
15.3 \%\end{array}$ & $\begin{array}{c}9 \\
36.0 \%\end{array}$ & $14.3 \%$ & 0 & $18.0 \%$ & $\begin{array}{l}13 \\
33.3 \%\end{array}$ & $\begin{array}{l}20 \\
16.1 \%\end{array}$ & 0 & $33.3 \%$ \\
\hline Total & $\begin{array}{c}30 \\
100 \%\end{array}$ & $\begin{array}{c}72 \\
100 \%\end{array}$ & $\begin{array}{c}46 \\
100 \%\end{array}$ & $\begin{array}{l}485 \\
100 \%\end{array}$ & $\begin{array}{l}25 \\
100 \%\end{array}$ & $\begin{array}{c}14 \\
100 \%\end{array}$ & $\begin{array}{c}32 \\
100 \%\end{array}$ & $\begin{array}{c}44 \\
100 \%\end{array}$ & $\begin{array}{c}39 \\
100 \%\end{array}$ & $\begin{array}{l}124 \\
100 \%\end{array}$ & $\begin{array}{c}9 \\
100 \%\end{array}$ & $\begin{array}{c}6 \\
100 \%\end{array}$ \\
\hline & $\begin{array}{l}N=6 \\
\text { Sig. }\end{array}$ & $\begin{array}{l}2, \text { Chi } \\
0.000\end{array}$ & qu. $=$ & 97.8 & & & $\begin{array}{l}N=2 \\
\text { Sig. }\end{array}$ & $\begin{array}{l}\text { 4, Chi } \\
0.000\end{array}$ & qu. & 8.7 & & \\
\hline
\end{tabular}

$d-t o-C B D$

\begin{tabular}{|c|c|c|c|c|c|c|c|c|c|c|c|c|}
\hline$<5$ miles & $\begin{array}{c}16 \\
53.3 \%\end{array}$ & $\begin{array}{c}37 \\
51.4 \%\end{array}$ & $\begin{array}{c}30 \\
65.2 \%\end{array}$ & $\begin{array}{l}325 \\
67.0 \%\end{array}$ & $\begin{array}{c}18 \\
72.0 \%\end{array}$ & $\begin{array}{c}9 \\
64.3 \%\end{array}$ & 0 & 0 & 0 & $\begin{array}{c}1 \\
0.8 \%\end{array}$ & 0 & 0 \\
\hline $5-14$ miles & $\begin{array}{c}12 \\
40.0 \%\end{array}$ & $\begin{array}{c}27 \\
37.5 \%\end{array}$ & $\begin{array}{c}13 \\
28.3 \%\end{array}$ & $\begin{array}{l}113 \\
26.6 \%\end{array}$ & $\begin{array}{c}4 \\
16.0 \%\end{array}$ & $21.4 \%$ & $\begin{array}{c}14 \\
43.8 \%\end{array}$ & $\begin{array}{c}20 \\
45.4 \%\end{array}$ & $\begin{array}{c}20 \\
51.3 \%\end{array}$ & $\begin{array}{c}60 \\
48.4 \%\end{array}$ & $\begin{array}{c}9 \\
100 \%\end{array}$ & $\begin{array}{c}5 \\
83.3 \%\end{array}$ \\
\hline $5-29.9$ miles & ${ }^{2} 6 \%$ & $\begin{array}{c}7 \\
9.7 \%\end{array}$ & $2.2 \%$ & $\begin{array}{l}32 \\
7.5 \%\end{array}$ & $12.0 \%$ & $\begin{array}{l}2 \\
14.3 \%\end{array}$ & $\begin{array}{c}15 \\
46.9 \%\end{array}$ & $\begin{array}{c}19 \\
43.2 \%\end{array}$ & $\begin{array}{c}14 \\
35.9 \%\end{array}$ & $\begin{array}{l}52 \\
41.9 \%\end{array}$ & 0 & $16.7 \%$ \\
\hline
\end{tabular}




\begin{tabular}{|c|c|c|c|c|c|c|c|c|c|c|c|c|}
\hline \multirow[b]{2}{*}{ Mode* } & \multicolumn{6}{|c|}{ White } & \multicolumn{6}{|c|}{ Nonwhite } \\
\hline & 1 & 2 & 3 & 4 & 5 & 7 & 1 & 2 & 3 & 4 & 5 & 7 \\
\hline $30-49.9$ miles & 0 & 0 & $\stackrel{1}{2.2 \%}$ & $\begin{array}{c}9 \\
1.9 \%\end{array}$ & 0 & 0 & $\begin{array}{c}3 \\
9.4 \%\end{array}$ & $\begin{array}{c}5 \\
11.4 \%\end{array}$ & $\begin{array}{c}5 \\
12.8 \%\end{array}$ & $\begin{array}{l}10 \\
8.1 \%\end{array}$ & 0 & 0 \\
\hline$>50$ miles & 0 & 0 & $\begin{array}{c}1 \\
2.2 \%\end{array}$ & $\begin{array}{c}6 \\
1.2 \%\end{array}$ & 0 & 0 & 0 & 0 & 0 & $\begin{array}{c}1 \\
0.8 \%\end{array}$ & 0 & 0 \\
\hline \multirow[t]{2}{*}{ Total } & $\begin{array}{c}30 \\
100 \%\end{array}$ & $\begin{array}{c}72 \\
100 \%\end{array}$ & $\begin{array}{c}46 \\
100 \%\end{array}$ & $\begin{array}{l}485 \\
100 \%\end{array}$ & $\begin{array}{c}25 \\
100 \%\end{array}$ & $\begin{array}{c}14 \\
100 \%\end{array}$ & $\begin{array}{c}32 \\
100 \%\end{array}$ & $\begin{array}{c}44 \\
100 \%\end{array}$ & $\begin{array}{c}39 \\
100 \%\end{array}$ & $\begin{array}{l}124 \\
100 \%\end{array}$ & $\begin{array}{c}9 \\
100 \%\end{array}$ & $\begin{array}{c}6 \\
100 \%\end{array}$ \\
\hline & \multicolumn{6}{|c|}{$\begin{array}{l}\mathrm{N}=672, \text { Chi-squ. }=29.3 \\
\text { Sig. }=0.250\end{array}$} & \multicolumn{6}{|c|}{$\begin{array}{l}\mathrm{N}=254, \text { Chi-squ. }=16.0 \\
\text { Sig. }=0.719\end{array}$} \\
\hline
\end{tabular}

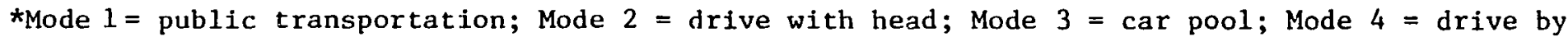
self; Mode 5 = walk; Mode 7 = other. 
The preceding crosstabulation tables, with nonrandom cross frequency distributions, show that spatial establishments have an effect on modal choice and hence on speed and time. 
APPENDIX E

THE EFFECT OF LOCATION FACTORS ON CHILDCARE COST

\begin{tabular}{|c|c|c|c|c|c|c|}
\hline & & White & & & Nonwhite & \\
\hline $\begin{array}{l}\text { Childcare Cost } \\
\text { (dollars/week) }\end{array}$ & Mean & Std.Dev. & $\underline{\mathrm{N}}$ & Mean & Std.Dev. & $\underline{\mathrm{N}}$ \\
\hline Region & & & & & & \\
\hline Northeast & 24.9 & 18.6 & 49 & 27.0 & 14.0 & 24 \\
\hline North Central & 23.6 & 12.4 & 90 & 25.2 & 10.4 & 42 \\
\hline South & 23.7 & 10.7 & 128 & 20.0 & 9.3 & 193 \\
\hline West & 29.3 & 13.4 & 43 & 22.1 & 9.8 & 35 \\
\hline Total & 24.7 & 13.2 & 310 & 21.6 & 10.2 & 294 \\
\hline & $\begin{array}{l}\text { Betwee } \\
\text { Sig. = }\end{array}$ & $\begin{array}{l}\text { n Group } F \\
0.083\end{array}$ & 2.2 & $\begin{array}{l}\text { Betwe } \\
\text { Sig. }\end{array}$ & $\begin{array}{l}=0.001\end{array}$ & $=5.8$ \\
\hline City Size & & & & & & \\
\hline$<25,000$ & 23.1 & 10.8 & 94 & 19.2 & 9.0 & 55 \\
\hline$>\begin{array}{l}\text { SMSA } \\
500,000\end{array}$ & 28.1 & 17.1 & 53 & 23.7 & 11.2 & 123 \\
\hline $\begin{array}{l}\text { SMSA } \\
100,000-499,999\end{array}$ & 25.3 & 13.6 & 87 & 20.4 & 8.7 & 71 \\
\hline $\begin{array}{l}\text { SMSA } \\
50,000-99,999\end{array}$ & 23.8 & 13.0 & 48 & 21.2 & 9.1 & 33 \\
\hline
\end{tabular}


White

Chilcare Cost

(dollars/week)

SMSA, NONSMSA

$25,000-49,999$

Total

$<5$ miles
$5-14.9$ miles
$15-29.9$ miles
$30-49.9$ miles
$>50$ miles

Total

Mean Std.Dev. N

22.7

9.8

28

24.7

13.2

310

Between Group $F=1.5$

Sig. $=0.200$

$24.4 \quad 13.2 \quad 198$

25.7

13.9

84

11.2

22

22.0

27.3

11.7

29.0

8.5

24.7

13.2

310

Between Group $F=0.4$

Sig. $=0.858$
Nonwhite

Mean Std.Dev. $\underline{N}$

$18.5 \quad 12.4$

12

$21.6 \quad 10.2 \quad 294$

Between Group $F=2.6$

Sig. $=0.030$

$21.8 \quad 11.0 \quad 151$

21.0

9.2

113

22.0

9.4

22

$26.0 \quad 15.5 \quad 2$

13.5

2.1

2

$21.6 \quad 10.2 \quad 294$

Between Group $F=1.1$

Sig. $=0.350$ 


\section{APPENDIX F}

FEMALE LABOR FORCE PARTICIPATION RATE, BIRTH RATE, DIVORCE RATE, AND AGE AT FIRST MARRIAGE

Female Labor Force 1

Participation Rate

Total White Nonwhite

1900

1910

1920

1925

1930

1935

1940

1945

1946

1947

1948

1949

1950

1951

1952

1953

1954

1955

1956
$20.0 \quad 17.3 \quad 41.2$

N/A N/A N/A

$\begin{array}{lll}22.7 & 20.7 & 40.6\end{array}$

$\mathrm{N} / \mathrm{A} \quad \mathrm{N} / \mathrm{A} \quad \mathrm{N} / \mathrm{A}$

$\begin{array}{lll}23.6 & 21.8 & 40.4\end{array}$

N/A N/A N/A

$\begin{array}{lll}25.7 & 24.5 & 37.3\end{array}$

35.9 N/A N/A

$31.1 \quad \mathrm{~N} / \mathrm{A} \quad \mathrm{N} / \mathrm{A}$

$\begin{array}{lll}31.8 & 28.7 & 41.0\end{array}$

$\begin{array}{lll}32.7 & 30.3 & 39.9\end{array}$

$33.1 \quad 29.9 \quad 40.1$

$33.9 \quad 31.1 \quad 42.1$

$\begin{array}{lll}34.6 & 31.8 & 41.5\end{array}$

$\begin{array}{lll}34.7 & 31.9 & 39.7\end{array}$

$\begin{array}{lll}34.4 & 32.3 & 39.6\end{array}$

$\begin{array}{lll}34.6 & 33.3 & 46.1\end{array}$

$\begin{array}{lll}35.7 & 34.5 & 46.1\end{array}$

$\begin{array}{lll}36.9 & 35.7 & 47.3\end{array}$ \begin{tabular}{c}
$\begin{array}{c}\text { Crude } \\
\text { Birth Rate }\end{array}$ \\
\hline
\end{tabular} 
Female Labor Force Participation Rate

Total White Nonwhite

\begin{tabular}{|c|c|c|c|c|c|c|}
\hline 1957 & 36.9 & 35.7 & 47.1 & 25.3 & 9.2 & 20.3 \\
\hline 1958 & 37.1 & 35.8 & 48.0 & 24.3 & 8.9 & 20.2 \\
\hline 1959 & 37.1 & 36.0 & 47.6 & 24.0 & 9.3 & 20.2 \\
\hline 1960 & 37.7 & 36.5 & 48.2 & 23.7 & 9.2 & 20.3 \\
\hline 1961 & 38.1 & 36.9 & 48.3 & 22.4 & 9.6 & 20.3 \\
\hline 1962 & 37.9 & 36.8 & 47.9 & 21.7 & 9.4 & 20.3 \\
\hline 1963 & 38.3 & 37.1 & 48.0 & 21.6 & 9.6 & 20.5 \\
\hline 1964 & 38.7 & 37.5 & 48.5 & 21.0 & 10.0 & 20.5 \\
\hline 1965 & 39.3 & 38.1 & 48.5 & 19.3 & 10.6 & 20.6 \\
\hline 1966 & 40.3 & 39.2 & 49.3 & 19.4 & 10.9 & 20.5 \\
\hline 1967 & 41.1 & 40.1 & 49.6 & 18.4 & 11.2 & 20.6 \\
\hline 1968 & 41.6 & 40.7 & 49.3 & 17.8 & 12.5 & 20.8 \\
\hline 1969 & 42.7 & 41.8 & 49.8 & 17.5 & 13.4 & 20.8 \\
\hline 1970 & 43.3 & 42.6 & 49.5 & 17.8 & 14.9 & 20.8 \\
\hline 1971 & 43.3 & 42.6 & 49.3 & 18.4 & 15.8 & 20.9 \\
\hline 1972 & 43.9 & 43.2 & 48.8 & 17.2 & 17.0 & 20.9 \\
\hline 1973 & 44.7 & 44.1 & 49.3 & 15.6 & 18.2 & 21.0 \\
\hline 1974 & 45.6 & 45.2 & 49.3 & 14.8 & 19.3 & 21.1 \\
\hline 1975 & 46.3 & 45.9 & 49.4 & 14.8 & 20.3 & 21.1 \\
\hline 1976 & 47.3 & 46.9 & 50.4 & 14.6 & 21.1 & 21.3 \\
\hline 1977 & 48.4 & 48.0 & 51.1 & 14.6 & 21.1 & 21.6 \\
\hline 1978 & 50.0 & 49.4 & 53.5 & 15.1 & 21.9 & 22.8 \\
\hline 1979 & 51.0 & 50.5 & 53.6 & 15.0 & 22.8 & 22.1 \\
\hline
\end{tabular}


Female Labor Force, Participation Rate

Total White Nonwhite

\begin{tabular}{lllllll}
1980 & 51.5 & 51.2 & 53.6 & 15.6 & 22.6 & 22.0 \\
1981 & 52.1 & 51.9 & 53.6 & 15.9 & 22.8 & 22.3 \\
\hline
\end{tabular}

${ }^{1}$ SOURCE: (a) U.S. Department of Labor, Bureau of Labor Statistics, September 1982, Bulletin 2096, Labor Force Statistics Derived From the Current Population Survey: A Databook, vol. I, p. 716, Table C-11.

(b) U. S. Department of Labor Statistics, September 1982, Bulletin 2096, Labor Force Statistics Derived From the Current Population Survey: A Databook, vol. II, pp. 328-329, Table E-2. (Rate for women 16 years and over.)

(c) U.S. Department of Commerce, Bureau of the Census, (1974), Historical Statistics of the United States: Colonial Time to 1957, p. 71, Series D13-25; p. 72, Series D26-35. (Rate for women 14 years old and over.)

2 SOURCE: U. S. Department of Commerce, Bureau of the Census, Statistical Abstract of the United States 1984, p. 63, Table 83.

${ }^{3}$ SOURCE: U. S. Department of Health and Human Services, Vital Statistics of the United States 1979, vol. III, Marriage and Divorce, Table 2-1. (Rate per 1,000 married women, 15 years old and over.)

${ }^{4}$ SOURCE: U. S. Department of Commerce, Bureau of the Census, (1982), Current Population Reports: Population Characteristics, Series P-20, No. 380, Marital Status and Living Arrangements, p. 2, Table B. 